\title{
INWENTARZ ZESPOLU AKT CYSTEREK-BENEDYKTYNEK TORUŃSKICH Z LAT 1311-1833
}

Niniejszy inwentarz ma charakter idealny i obejmuje lata działalności twórcy zespohu akt. Sporządzono go w celu zebrania wszystkich, także rozproszonych i niezachowanych do dziś materiałów archiwalnych, wchodzących niegdyś w skład archiwum cysterek-benedyktynek toruńskich ${ }^{1}$. Może on spełniać różne role: usprawnić realne scalanie zespołu oraz ułatwić kwerendę badaczom monastycyzmu żeńskiego, którzy zainteresowani będą dziejami Kongregacji Chełmińskiej, toruńskiego zgromadzenia lub szczegółowymi aspektami jego działalności.

Archiwalia należące do powyższego zespołu akt znajdują się w: Archiwum

*Jolanta Kurek - absolwentka Wydziahu Nauk Historycznych UMK w Toruniu, pracownik Biblioteki Uniwersyteckiej Uniwersytetu Mikołaja Kopernika w Toruniu.

${ }^{1}$ Termin cysterki - benedyktynki jest tu stosowny na określenie specyficznych wspólnot cysterck obediencji biskupiej. Niektóre z nich nie będąc inkorporowane do Sacer Ordo Cisterciensis, lub będąc pozbawione realnej opieki zakonnej, przcehodziły w okrcsie średniowiecza silny kryzys swojej tożsamości monastyczncj. W wyniku czego, opactwa te swoje pierwotne zwyczaje mieszały z benedyktyńskimi, tworząc specyficzną obserwancję monastyczną. Okresowo zachowywane zwyczaje mieszane mogly być przenoszone prawdopodobnie poprzez filjację do powstających w tym czasie opactw i pielęgnowane w nich zapewne jako „tradycyjna obserwancja”. Sprawy wewnętrzne opactwa regulowano i rozpatrywano więc w oparciu o tradycje a nie konstytucje. Nie tylko dziś, ale i w okresie reformy trydenckiej, nie byly znane przyczyny powstawania tego rodzaju zwyczajów. W XVI wieku wizytator cystersów, o. Edmund a Cruce, obarczył biskupów diecezjalnych winą za powstanie mieszanej obserwancji monastycznej (zob. Monumenta Poloniae Vaticana, wyd. J. Ptaśnik, t. 4, Kraków 1915, s. 815 i inn.; J. Seyda, Zagadnienie reformy zakonów w Polsce, ,Roczniki Teologiczno-Kanoniczne“, 13 (1966) z. 4, s. 106-107, 117). Powyższy termin ma za zadanie wyróżnić wspomniane wspólnoty od tych klasztorów cysterek obediencji biskupiej, które mimo braku opieki ze strony Sacer Ordo Cisterciensis nie przechodziły wyrá́nego kryzysu tożsamości zakonnej, o czym świadczył fakt, iz nigdy nie były nazywane oraz same się nie nazywały raz cysterkami a następnym razem benedyktynkami w źródłach historycznych (np. klasztory cysterek biskupich w Cedyni, Gardźcu, Koszalinie, Marianowie, Pelczycach, Reczu, Szczecinie, czy w Wolinie). Krótko o tych klasztorach zob.: M. Borkowska, Stownik mniszek benedyktyniskich w Polsce, Tyniec 1989, 
Diecezjalnym w Pelplinie, Archiwum Państwowym w Toruniu, Archiwum kościoła parafialnego pw. św. Jakuba w Toruniu oraz Archiwum Akt Dawnych Diecezji Toruńskiej w Toruniu². Część opracowanych materiałów zaopatrzono niegdyś w pomoce archiwalne ${ }^{3}$. Materiały dziś nieistniejące zostały po części odtworzone dzięki kilku edycjom źródłowym dotyczącym historii diecezji chełmińskiej, miasta Torunia a nawet samych zakonnic toruńskich4.

Klasztor toruńskich cysterek-benedyktynek rozpoczął swoją egzystencję w 1311 r., w ramach diecezji chełmińskiej, na terenie państwa Zakonu Krzyżackiego w Prusach ${ }^{5}$. W 1466 r. diecezja ta znalazła się w granicach Państwa Polskiego, lecz do 1566 r. (od 1255 r.) pozostawała w zwiazku metropolitarnym z Ryga, natomiast później weszła w skład metropolii gnieźnieńskiej ${ }^{6}$. W wyniku rozbiorów diecezja chełmińska znalazła się w całości w państwie pruskim ${ }^{7}$. Przynależność wspomnianej diecezji, a więc także zakonnic toruńskich, do państwa pruskiego

s. 42-43, 48, 56-57, 77, 89-90, 97, 109-111, 125. Wcześniej termin cysterki-benedyktynki toruńskie uźywany był $w$ zupelnie innym znaczcniu: przypuszczano istnienic $w$ średniowiecznym Toruniu dwóch konwentów żeńskich (cysterek i benedyktynck) oraz że nazwa i reguła po ich unifikacji przez pewien czas utrzymywały się w obu gałęziach nowej wspólnoty, zob. M. Biskup, Sredniowieczna sieć klasztorów w państwie zakonu krzyzackiego, „Zapiski Historyczne”, 1 (1999) s. 50; K. Ciesielska, Inwentarz, Akta klasztorów toruniskich, Grupa zespolów 1232-1834, opr. K. Ciesielska, Tonuń 1973 (maszynopis znajduje się w Archiwum Państwowym w Toruniu), s. 1-2, 13. Zastosowanie tego terminu w stosunku do zgromadzenia toruńskicgo ma także podkreślić fakt, że klasztor założony w średniowieczu jako cysterski, w wyniku reformy i wejścia w skład Kongregacji Chelmińskiej stał się benedyktyńskim.

${ }^{2}$ Od początku 2005 r. są tam przechowywane akta z dziahu Monastica, przekazane przez Archiwum Diecezjalne w Pelplinic.

${ }^{3}$ Znaczną część materiałów z tego zespohı uporządkowal i spisal ks. Paweł Czapiewski -- zob. Relacja z porządkowania Archiwum benedyktynek torunskich autorstwa ks. Pawła Czaplewskiego (rękopis w Archiwum Państwowym w Toruniu, umieszczony pośród inwentarzy w osobnej teczce pod nazwą Archiwum św. Jakuba w Tonıniu). Do wspomnianych pomocy archiwalnych nalcżą: K. Ciesielska, Inwentarz: Akta klasztorów torunskich, A. Nadolny, Archiwum Diecezjalne w Pelplinie. Zarys dziejów i informacja o zasobie, „Studia Pelplinskie”, 14 (1990/1991) s. 263-282.

${ }^{4}$ Są to dokumenty i akta opublikowane w całości lub zregestowane w Preussisches Urkundenbuch, Bd. I-VI, Königsberg 1882-Marburg /L.1986; Urkundenbuch des Bisthums Culm, Bd. I-II, bearb. v. C. P. Woelky, Danzig 1885-1887; Kronika benedyktynek toruńskich, wyd. W. Szoldrski, Pelplin 1934, C. P. Woelke, Regesten und Urkunden-Verzeichnis über das Benedictiner-Jungfrauenkloster in Thorn, Altpreussis. Monatschr., Bd. 17 (1880), H: 7-8, s. 589-642.

${ }^{5}$ A. Radzimiński, Podziaty kościelne, w: Państwo zakonu krzyżackiego w Prusach. Podziaty administracyjne $i$ kościelne od XIII od XVI w., red. Z. H. Nowak, R. Czaja, Torun 2000, s. 71; P. Oliński, Motywy fundacji klasztorów przez Zakon Krzyzacki $w$ Prusach $w$ świetle dokumentów fundacyjnych (ze szczególnym uwzględnieniem dokumentów fundacyjnych żeńskiego klasztoru benedyktyriskiego w Królewcu i klasztoru augustianów-eremitów w Chojnicach), w: Kancelarie krzyżackie, Stan badań i perspektywy badawcze, Materiaty z Międzynarodowej Konferencji Naukowej, Malbork 18-19.X.2001, red. J. Trupindy, Malbork 2001, s. 193.

${ }^{6}$ H. E. Wyczawski, Przygotowanie do studiów w archiwach kościelnych, Kalwaria Zebrzydowska 1989, s. 21-22.

7 Wyczawskj, Przygotowanie, s. 36-37; Nadolny, Archiwum Diecezjalne w Pelplinie, s. 265. 
przerwało na krótko istnienie Księstwa Warszawskiego ${ }^{8}$. Ostatecznie toruńska wspólnota została zlikwidowana w 1833 r. przez rząd pruski w ramach trzecicj dużej akcji kasacyjnej instytucji zakonnych przeprowadzanej w latach 1815-1841. Przyczyną likwidacji był pogląd władz, że instytucje zakonne stanowiły przeszkodę w integracji Wielkiego Księstwa Poznańskiego oraz Pomorza i Warmii z resztą państwa pruskiego poprzez swoje powiązania organizacyjne i personalne $z$ pozostałymi obszarami dawnej Rzeczypospolitej ${ }^{9}$.

Zakonnice toruńskie przez cały okres swojego istnienia funkcjonowały jako wspólnota obediencji biskupiej. Mimo uznawania przez niektórych badaczy klasztoru toruńskiego za egzymowany spod władzy biskupiej ${ }^{10}$, znalazło się wiele dowodów na jego pozostawanie pod wpływem i opicką micjscowych biskupów (do wejścia toruńskich mniszek w skład Kongregacji Chełmińskiej) ${ }^{11}$. W okresie późniejszym, czyli po $1632 \mathrm{r}$, jest to już fakt niewątpliwy ${ }^{12}$. Z kolei w sprawach świeckich klasztor toruński podlegał władzom państwowym ${ }^{13}$.

Natomiast życie wspólne toruńskiego zgromadzenia w okresie średniowiecza przynajmniej z założenia (w praktyce bywało różnie) wytyczała Reguła św. Benedykta $z$ Nursji oraz konstytucje cysterskie ${ }^{14}$. W 1626 r. toruńska wspólnota uważająca się za benedyktyńska, posługiwała się nadal Regułą św. Benedykta z Nursji, lecz obwarowaną dodanymi do nicj konstytucjami, których autorami byli księża $z$ otoczenia ówczesnego chełmińskiego ordynariusza, wzorujący się w ich pisaniu na wzorcach niemieckich. Była to „Reguła św. Ojca Benedykta, z dawna władzą Stolice Apostolskiej potwierdzona, a teraz na polski język z konstytucjami albo ustawami tegoż bł. Patriarchy dla panien zakonnych zgromadzenia kassyneńskiego wiernie przełumaczona", Toruń 1626 (unikatowa, gdyż jej nakład zniszczono w 1634 r.), czyli „Reguła Starożytnego Zakonu Oyca Benedykta”, w odróżnieniu od funkcjonującej w tym czasie Reguły chełmińskiej. W 1632 r., po przystąpieniu toruńskiej wspólnoty do Kongregacji Chełmińskiej, doszło jednak do zmiany dotychczas zachowywanych ustaw na Regułę chełmińska, która była dzicłem samej Magdaleny Mortęskiej oraz wspomagających jąjezuitów (zatwierdzona przez papieża jeszcze w 1605 r. Reguła nie była uzupełniona, jak w przypadku toruńskim, poprzez podane do niej konstytucje, a więc na wzór cysterski,

${ }^{8}$ Wyczawski, Przygotowanie, s. 38-39.

${ }^{9}$ Wyczawski, Przygotowanie, s. 116; Diecezja Toruńska, Historia i teraźniejszość, t. 1, Toruń 1994, s. 146-147.

${ }^{10}$ F. Bohdan, Sprawa wyjęcia polskich zakonów spod wladzy biskupiej w epoce przedtrydenckiej. Studia prawno-historyczne, „Sacnum Poloniae Millenium“, 10 (1964) s. 70-71, F. Winter, Cistercienser des nordöstlichen Deutschlands, Bd. II, Gotha 1871, s. 119.

${ }^{"}$ Zob. UBC, I, nr 394, 473, 474, 489; 550; UBC, II, nr 718, 742, 747, 748, 1129, 1132; J. Kolberg, Ein Preussisches Formelbuch, Zeitschrift für die Geschichte und Alterthumskunde Ermlands, Bd. 9 (1891), nr 67; C. P. Woelky, Regesten, nr 36, 42, 136.

${ }^{12}$ A. Jak, Stosunek biskupa chetminiskiego do klasztoru, sygn. tymcz. ZC-B/4.

${ }^{13} \mathrm{M}$. Borkowska, Życie codzienne polskich klasztorów żeńskich w XVII-XVIII wieku, Warszawa 1996, s. 237.

${ }^{14}$ Kronika benedyktynek chelminskich, wyd. W. Szołdrski, Tonnn 1934, s. 99-100. 
ale poprzez deklaracje umieszczone pod każdym niemal każdym jej rozdziałem). Od tej pory toruńskie mniszki stały się bezsprzecznic benedyktynkami obserwancji chełmińskiej ${ }^{15}$.

Dwukrotnie w historii zespołu akt cysterek-benedyktynek toruńskich przeprowadzono prace mające na celu zabezpieczenie cennych archiwaliów przed zniszczeniem. Zmikrofilmowano księgi rachunkowe znajdujące się w Archiwum parafialnym pw. św. Jakuba w Toruniu oraz zdigitalizowano znaczną część ksiąg i akt z okresu staropolskiego i kilka jednostek archiwalnych dotyczących kasaty, przechowywanych w powyższym archiwum oraz w Archiwum Diecezjalnym w Pelplinie.

Nadając wspomnianym materiałom wspólny układ przyjęto rzeczową metodę porządkowania zespołu. Wpłynał na to fakt, iż nie można było odtworzyć choćby idealnie (na podstawie zachowanych informacji źródłowych) wielu jednostek dotyczących spraw organizacyjnych, prawnych, personalnych oraz związanych z liturgią i szeroko pojętą duchowością toruńskiej wspólnoty, które zawierały informacje (poprzez sygnatury dawne) o dawnym układzie archiwum klasztornego. Ponadto zachowane materiały będące pozostałością archiwum cysterek-benedyktynek przypominają zespoly akt pochodzące $\mathrm{z}$ archiwów prywatnych, dla których ta metoda porządkowania jest metodą właściwą ${ }^{16}$. Rzeczowy układ archiwaliów zespołu cysterek-benedyktynek składa się z następujących serii:

1. Dokumenty.

2. Organizacja. Życie codzienne i duchowe wspólnoty.

3. Rozporządzenia władz duchownych i świeckich. Korespondencja.

4. Sprawy sądowe.

5. Majątki ziemskie i inne nieruchomości.

6. Przychody i rozchody klasztoru.

7. Przedsiębiorstwa klasztorne.

8. Działalność charytatywna.

9. Nowe fundacje klasztoru toruńskiego.

10. Kościoły parafialne i inne budynki klasztorne.

11. Varia. Różne sprawy klasztorne. Korespondencja.

12. Extranea. Akta nie związane z klasztorem.

Mimo zastosowania rzeczowej metody porządkowania zachowano istniejący we wszystkich archiwach przechowujących powyższe archiwalia podział na dokumenty $\mathrm{i}$ inne formy kancelaryjne. Ponadto w ramach utworzonej serii Dokumenty wymieniono wszystkie jednostki archiwalne znajdujące się

${ }^{15}$ Borkowska, Życie codzienne, s. 187-192; Borkowska, Panny siostry w świecie sarmackim, Warszawa 2002, s. 264-271, 357.

${ }^{16}$ Pewien wpływ na przyjęty układ archiwaliów w zespole akt cysterek - benedyktynek toruńskich miały też artykuly dotyczące archiwów klasztornych domów męskich: K. Kaczmarczyk, Porzadkowanie archiwów klasztornych, „Archcion”, 47 (1967) s. 7-22; R. Prejs, Struktura zasobu archiwów zakonów męskich, ABMK, 70 (1998) s. 45-60; tenże, Organizacja i funkcjonowanie archiwów w domach zakonnych, ABMK, 75 (2001) s. 139-152. 
w zasobach wspomnianych archiwów (obok dziś nieistniejących) ze względu na idealny charakter inwentarza i jego cele: $\mathrm{m}$. in. informowanie o obecnym stanie i miejscu przechowywania j. a. należących do zespołu. Spowodowało to jednak pewne komplikacje. W serii tej znalazły się (w nielicznych wypadkach) zarówno oryginały, jak i kopie tych samych dokumentów. Aby ujednolicić występujące w dokumentach niekonsekwencje dotyczące nazywania lub deklarowania się zakonnic toruńskich cysterkami bądź benedyktynkami posłużono się terminem cysterki-benedyktynki (do uwag przenosząc informację o rzadko występującym w nich określeniu przynależności zakonnej twórcy zespołu). Następnie, po wejściu niniejszego zgromadzenia w skład Kongregacji Chełmińskiej, określano je mianem benedyktynek.

W przypadku wszystkich zachowanych tytułów jednostek inwentarzowych poszanowano ich oryginalną pisownię. Ze względu na idealny, a nie realny charakter inwentarza $w$ trakcie porządkowania nie przeprowadzono łączenia ani tez podziału istniejących j. a. (zwłaszcza, że nie tylko teki zawierające luzy czy poszyty, ale nawet stare księgi wpisów zawierały różnorodne treści). Spowodowało to w kilku przypadkach komplikacje, gdyż nie zawsze dana j. a. mogła odpowiadać, ze względu na swą różnorodność, jednej tylko serii. Zaliczano więc ją do serii którą sugerował tytuł bądź większość znajdujących się w niej materiałów, zamieszczając uwagi o zawartych w niej innych, bardziej nieoczekiwanych informacjach. Również ze względu na wspomniany wyżej charakter inwentarza utworzono serię Varia. Różne sprawy klasztorne. Korespondencja (oznacza to, że nie dzielono i nie opracowywano na nowo jednostek zatytułowanych Varia, starając się w uwagach poinformować o treści tak opisanych akt). Innym wyjątkiem jest seria Extranea. Akta nie związane z klasztorem, w której obok ksiag i akt znalazły się dwa dokumenty. Wyjątkowo zastosowano wobec nich jedynie podział rzeczowy, nie tylko ze względu na ich małą ilość, ale i fakt, że nie są w żaden sposób powiązane $z$ istnieniem $i$ działalnością toruńskich cysterek-benedyktynek. W niniejszym inwentarzu nie zamieszczono odnalezionego wśród materiałów archiwalnych spisu ksiag $\mathrm{z}$ biblioteki konwentualnej toruńskich zakonnic z $1617 \mathrm{r}$, ponieważ będzie on przedmiotem odrębnej publikacji (pominięto więc serię Biblioteka).

Ponieważ zestawione materiały znajdują się w różnych archiwach, pierwsza sygnatura dawna oznacza ostatnie miejsce przechowywania danej j. a. Często też w przypadku odtworzenia jednostki obecnie nieistniejącej podawano $\mathrm{w}$ miejscu sygnatury dawnej źródło pochodzenia informacji o jednostce lub jej treści, dodając ponadto różne szczegóły na ten temat w uwagach. W tekście publikowanego inwentarza, w obrębie podanych wcześniej serii, przy zachowaniu ciąłłej numeracji wymieniono poszczególne jednostki archiwalne. Ich opis składa się $z$ następujących elementów: daty i miejsca wydania (w serii dokumenty); zapisu tytułu oryginalnego lub urobionego; dat krańcowych jednostki (w pozostałych seriach) oraz ewentualne anteriorów i posteriorów; a także w miarę możliwości również z opisu zewnętrznego, fizycznego i postaci jednostki; języka; liczby kart lub stron; formatu jednostki inwentarzowej; dawnych sygnatur; uwag archiwalnych, historycznych i danych bibliograficznych.

Powstanie inwentarza zespołu akt cysterek-benedyktynek toruńskich swoje 
istnienie zawdzięcza pomysłowi i pomocy pana prof. dra hab. Andrzeja Radzimińskiego, któremu za opiekę naukową i cenne sugestie dziękuję.

Dziękuję także ks. prof. Anastazemu Nadolnemu oraz ks. prałatowi Andrzejowi Wawrzyniakowi za udostępnienie mi powierzonych ich opiece archiwaliów oraz za serdeczność i zaufanie.

\section{Wykaz skrótów}

ADPel. - Archiwum Diecezjalne w Pelplinie

AGAD - Archiwum Główne Akt Dawnych

A Jak. - Archiwum przy kościele parafialnym pod wezwaniem św. Jakuba w Toruniu

Altpr. Monatschr. - Altpreussische Monatschrift

AP - Archiwum Państwowe

APGd. - Archiwum Państwowe w Gdańsku

APT - Archiwum Państwowe w Toruniu

ABMK - Archiwa, Biblioteki i Muzea Kościelne

Arch. UMK - Archiwum Uniwersytetu Mikołaja Kopcrnika

Bd. - Band

Bearb. - bearbeitet

Bifol. - bifolium

Codex Diplom Pruss. - Codex Diplomaticus Prussicus, Urkunden-Sammlung zur älteren

Geschichte Preussens hrsg.v. J.Voigt, Bd. 1-6, Königsberg 1836-1861.

flor. - floren

guld.- gulden

hrsg. - herausgegeben

Jahrg. - Jahrgang

KBCH - Kronika benedyktynek chełmińskich, wyd. W. Szołdrski, Pelplin 1934.

KBT - Kronika benedyktynek torunskich, wyd. W. Szołdrski, Pelplin 1934.

Kat. D. i L. K. - Katalog dokumentów i listów krzyżackich w AP w Toruniu, wyd.

A. Radzimiński, J. Tandecki, t. 1, Warszawa 1994.

Kat. D. i L. Król. - Katalog dokumentów i listów królewskich w AP w Toruniu, wyd. A.

Radzimiński, J. Tandecki, t. 1, Warszawa 1999.

kop. - kopia; kopiariusz

Kr.Ub. - Kirchliches Urkundenbuch der Neustadt Thorn 1263-1455 (Kr. Ub.), bearb. v.

A. Semrau, Mitteilungen des Copernicus-Vereins für Wissenschschaft und Kunst zu Thorn, Bd. 38 (1930).

Mies. Diec. Chełm. - Miesięcznik Diecezji Chełmińskiej

N. M. Toruń - Nowe Miasto Toruń

$\mathrm{Nr}$ - numer

Oryg. - Oryginat

Pap. - papier

Perg. - Pergamin

Pł. - Płyta

pol. - polski 
Pommerell.Ub - Pommerellisches Urkundenbuch, hrsg. v. M. Perlbach, Danzig 1882.

Pr. - Preussen

Pr. Ub - Preussisches Urkundenbuch, hrsg. v. M. Koeppen, Bd. I-VI, Königsberg 1882Marburg/L.1986.

Reg. - Regest

Roczn. Teol.-Kanon. - Roczniki Teologiczno- Kanoniczne

S. M. Toruń - Stare Miasto Toruń

Scrip. Rer. Pruss. - Scriptores Rerum Prussicarum, hrsg. V. T. Hirsch, M. Töppen, E. Strchlke, Bd. 1, Leipzig 1861.

Stud. Pelp. - Studia Pelplińskie

Sygn. tymcz. - sygnatura tymczasowa

Thorn. Denk. - Thorner Denkwürdigkeiten von 1345-1547, hesg. A:Voigt, Mitteilungen des Copernicus-Vereins für Wissenschschaft und Kunst zu Thorn, Bd.13 (1904).

u. - und

UBC - Urkundenbuch des Bisthums Culm, Bd. 1-2, bearb. v. C. P. Woelky, Danzig 1885-1887.

UBS - Urkundenbuch des Bisthums Samland, Bd. I, hrsg. v. C. P. Woelky, H. Mendthal, Leipzig 1891.

v. - von

Zap. Hist. - Zapiski Historyczne

$Z$ d. - zdigitalizowana (jednostka)

Zeitschr. d. Westpr.Geschichtver. -Zeitschrift des Westpreussischen Geschichtsvereins

Zeitschr. f. d. Gesch. Ermlands - Zeitschrift für die Geschichte und Alterthumskunde Ermlands

Zmkrf. -- zmikrofilmowana (jednostka)

\section{Dokumenty}

1311, (brak dokładnej daty i miejsca)

[Karol z Trewiru, wielki mistrz, funduje klasztor cysterek-benedyktynek w Toruniu przy szpitalu Św. Ducha jako wotum za zwycięstwo nad Litwinami pod Święta Lipka..]

Oryg. niezachowany.

Uwagi: Fakt dokonania fundacji jest znany ze wzmianki o bitwie i ufundowaniu klasztoru: Chronica Terre Prussie, Pars III, Petri de Dusburg, w: Scrip. Rer. Pruss., Bd. I, s. 176; M. Muri n iu s, Kronika Mistrzów Pruskich, Olsztyn 1989, s. 113; KBT, s. 5-6. 
1319, 28 października, Braniewo

in die bb.apostolorum Simones et Judae

[Eberhard, biskup warmiński, nadaje toruńskim i chełmińskim cysterkom-benedyktynkom odpust na święto i oficjum św. Klary.]

Oryg. Perg. rękopis, język łaciński.

Uwagi: Dokument nieistniejący, znany z kopiarza nr 5, fol. 7 oraz 2, fol. 2. Druk: UBC, I, nr 182;

Reg. C. P. Woelky, Regesten, nr 3, s. 590-591; KBT, s. 7.

\section{7, 4 października, Toruń}

in die $S$. Francisci Confessoris

[Werner von Orseln, wielki mistrz, translokuje klasztor cysterek-benedyktynek z dawnej jego siedziby przy szpitalu Św. Ducha na Przedmieściu Portowym do nowej przy kościele św. Krzyża na Przedmieściu Chełmińskim.]

Oryg. zaginiony. stan dobry, rękopis, język niemiecki.

A. Jak. nr 1.

Uwagi: Znany z Kopiarza nr 4, fol. 19, nr 9, fol.168. Tansumowany przę kapitułę chełmińską 21 listopada 1619 roku. Druk: UBC, I, nr 219; Reg. Pr. Ub., Bd. II, nr 594; C. P. Woelky, Regesten, nr 4, s. 591; Thor. Denk., s. 44-47; KBT, s. 7.

1328, 1 czerwca, Malbork

undecima kalendis junii

[Werner von Orseln, wielki mistrz, nadaje klasztorowi cysterek-benedyktynek w Toruniu wsie: Kamionki, Nowy Dwór, Rewan i Zelgno.]

Kop. Perg., stan dobry, rękopis, język łaciński, wym. 310x265 mm.

APT, Klasztor cysterek-benedyktynek, A. Dokumenty, nr 5; Scrinium XIV, nr 31.

Uwagi: Dokument zachowany w formie transumptu wystawionego przez Radę Miasta Tonunia 24.XIL.[14]82 roku. Druk: UBC, I, nr 220; Reg. C. P. Woclky, Regesten, nr 5, s. 951; Pr. Ub. , Bd. II, nr 618; Kat. D. i L. K., t. 1 , nr 17a, s. 9.

1330, 15 maja, Malbork

indictione 13, idus maii

[Werner von Orseln, wielki mistrz, nadaje toruńskim cysterkom-benedyktynkom prawo patronatu nad kościołem parafialnym oraz kaplicą Panny Marii w Szynwałdzie.] 
Oryg. Perg., stan dobry, rękopis, język łaciński, wym. $525 \times 290+65 \mathrm{~mm}$.

\section{APT, Klasztor cysterek-benedyktynek, A. Dokumenty, nr 14.}

Uwagi: Druk: UBC, I, nr 229; Reg. Kat. D. i L. K., t. 1, nr 17b, s. 9; KBT, s. 7. Dokument zachowany w formie transumptu Zygmunta Augusta, króla polskiego z dnia 25.II.1917 roku.

\section{6}

\section{0,15 maja}

indictione 13, idus maii

[Werner von Orseln, wielki mistrz, nadaje toruńskim cysterkom-benedyktynkom prawo patronatu nad kościołem parafialnym oraz kaplicą Panny Marii w Szynwałdzie.]

Kop. Perg., do konserwacji, rękopis, język niemiecki, wym. 280x285 mm.

\section{A. Jak nr 2.}

Uwagi: Druk: Reg. C. P. Wo elky, Regesten, nr 6, s. 591. Znany z kopiarzy nr 4, fol. 21-22; nr 5, fol. 23; nr 8, fol. 364. Transumpt Zygmunta III z dnia 3.III.1601 roku - kop. nr 4, fol, 21. Potwierdzenie z 25.II.1617 roku- kop. nr 4, fol. 22-23.

\section{7}

1330, 25 lipca, Prabuty

in die b. Jacobi apostoli, pontificatus anno IX

[Rudolf, biskup pomezański, transumuje dokument Wernera von Orseln, wielkiego mistrza, nadający klasztorowi toruńskich cysterek-benedyktynek prawo patronatu nad kościołem parafialnym oraz kaplicą Panny Marii w Szynwałdzie.]

Oryg. zaginiony, rękopis, język łaciński.

AP Gd. Abt. 51, nr 103.

Uwagi: Znany z XV-wiecznego odpisu znajdującego się w AP w Gdańsku, (Abt. 51, nr 103, fol. 41). Druk: Pr. Ub., Bd. Il, nr 692.

\section{8}

1333, 15 lipca, Toruń

die divisionis Apostolorum

[Luter, książę brunszwicki, wielki mistrz, potwierdza zamianę młyna na rzeczce Bielicy dokonaną przez klasztor cysterek-benedyktynek toruńskich z Rüdigerem, komturem z Kowalewa, na młyn na rzeczce Laka.]

Kop. Perg., do konserwacji, rękopis, język łaciński.

A. Jak., sygn.tymcz. ZC-B/14; Kopiariusz nr 4.

Uwagi: Znany jako XVII-wieczny odpis z kop. nr 4, fol. 24. Druk: UBC, I, nr 237; Reg. C. P. Woelky, Regesten, nr 7, s. 591; KBT, s. 7. Zakonnice toruńskie występują w tym dokumencie jako benedyktynki. 


\section{9}

1335, 12 grudnia, (brak miejsca)

II idus decembris, pontificatus anno I

[Benedykt XII, papież, przyjmuje klasztor cysterek-benedyktynek w 'Toruniu pod opiekę św. Piotra.]

Kop. Perg. Obecnie zaginiony, rękopis, język laciński.

A. Jak., nr 3.

Uwagi: Druk: UBC, I, nr 251; Reg. C. P. Woelky, Regesten, nr 8, s. 591-592. Zakonnice tonunskie występują w tym dokumencic jako benedyktynki.

\section{0}

\section{6, 17 września, Torun}

\section{Kalendas Octobris}

[Brat Werner, minister miniorytów z Torunia (należący do Prowincji Saskiej), przyjmuje do wspólnoty modlitewnej i uczestnictwa w dobrach duchowych swojego zakonu toruńskie cysterki-benedyktynki.]

Oryg. niezachowany, rękopis, język taciński.

\section{A. Jak., sygn. tymez. ZC-B/14 i 17; Kopiariusz nr 2 i 4.}

Uwagi: Znany z odpisu w kop.nr 2, fol. 1; kop. nr 4, fol. 25. Druk: UBC, I, nr 252; Reg. C. P. Woelky, Regesten, nr 9, s. 592; KBT, s. 7.

\section{1}

\section{3, 20 lipca, Toruń}

proxima dominica ante diem b. Marie Magdalene

[Otto, biskup chełmiński, cystersi z Pelplina oraz klasztory cysterek-benedyktynek z Torunia i Chełmna zrzekają się odszkodowań wojennych od króla polskiego.]

Oryg., rękopis, język laciński.

AGAD, nr 15 (A).

Uwagi: Druk: UBC, I, nr 276;Cod. Dipl. Regn. Pol., Bd. 4, nr 66; Reg. Cod. Dipl. Pruss., Bd. 3, s.V; Pr. Ub., Bd. III, nr 588, s. 469-470.

\section{2}

1345,6 stycznia, Malbork

in Epiphania Domini

[Ludolf König, wielki mistrz, potwierdził posiadanie prawa patronatu nad kościołem św. Jakuba w Nowym Mieście Toruniu nadanego toruńskim cysterkom-benedyktynkom przez jego poprzednika Teodoryka z Altenburgu.] 
Oryg. Perg., do konserwacji, rękopis, język laciński.

\section{A. Jak., nr 4; nr 19.}

Uwagi: Potwierdzony przez Zygmunta II 3.III.1601 roku (A. Jak. nr 25). Znany z kop. nr 4, fol. 35-36; kop. nr 9, fol. 170. Druk: UBC, I, nr 281; Reg. Pr. Ub., Bd. III, nr 424, s. 292; C. P. Woelky, Regesten, nr 10, s. 592; Thor. Denk., p. 52; KBT, s. 8.

\section{3}

1345, (brak dokładnej daty i miejsca)

[Nadanie prawa patronatu toruńskim cysterkom-benedyktynkom nad kościołem parafialnym w Świerczynkach.]

Oryg. niezachowany, rękopis.

Uwagi: Wiadomość o nim dzięki aktom wizytacji biskupstwa chełmińskiego z 1. 1667-1672, które znajdowały się w XIX w. w AP w Gdańsku. Druk: Reg. Pr. Ub., Bd. III/2, nr 756, s. 647-648.

\section{4}

\section{6, 25 maja, Lipno}

uffart unsers herrn

[Henryk Dusemer, wielki mistrz, poświadzcza, że mieszczanie starotoruńscy zbudują szpitalowi Św. Ducha bramę i spichrz. Ponadto zezwala on na doprowadzenie do szpitala wody z rowów miejskich, wykopanie studni oraz założenie ogrodu.]

Oryg. Perg., do konserwacji, rękopis, język niemiecki.

\section{A. Jak. nr 5.}

Uwagi: Znany też z kop. nr 4, fol. 40. Druk: UBC, I, nr 283; Reg. C. P. Woelky, Regesten, nr 11, s. 592; KBT, s. 8.

\section{5}

1346, 25 maja, Lipno

uffart unsers herrn

[Henryk Dusemer, wielki mistrz, poświadzcza, że mieszczanie starotoruńscy zbudują szpitalowi Św. Ducha bramę i spichrz. Ponadto zezwala on na doprowadzenie do szpitala wody z rowów miejskich, wykopanie studni oraz założenic ogrodu.]

Kop. Perg., stan dobry, rękopis, język niemiecki, wym. 280x225 mm.

APT, Dokumenty i listy, nr 41; Scrinium XIV, nr 8, 9; nr 74.

1347, 30 maja, (brak miejsca)

an des leychnamas abende 
[Heinrich von Kranichfeld, komtur bierzgłowski, zezwala braciom Selhorne dać toruńskim cysterkom-benedyktynkom łąkę zwaną proboszczowską.]

Oryg. Perg., rękopis, język niemiecki.

\section{A. Jak., sygn. tymcz. ZC-B/14; Kopiariusz nr 4 .}

Uwagi: Znany z odpisów. kop. nr 4, fol. 49. Druk: Reg. C. P. Woclky, Regesten, mr 12, s. 592; KBT, s. 8 .

\section{7}

[1352, 4 maja]

[Winrych von Knieprode, wielki mistrz, zwalnia mieszkańców wsi szpitalnej Pigży $z$ uczestnictwa w wyprawie na Litwę oraz ze specjalnych świadczeń finansowych na ten cel utrzymując obowiązek szarwarku.]

Oryg. zaginiony, rękopis, język niemiecki.

Uwagi: Dokument znany z regestu znajdującego się w XIX w. w AP. w Królewcu. Druk: Reg. Pr. Ub., Bd. V/1, nr 49, s. 27.

\section{8}

1352, 15 października, Toruń

in crastino sancti Kalixti pape et martyris.

[Brat Dytryk von Brandenburg, komtur toruński, potwierdza sprzedaż młyna w Młyńcu przez klasztor cysterek-benedyktynek toruńskich niejakiemu Janowi Pnichicher i jego potomkom.]

Oryg. Perg., rękopis, język niemiecki.

A. Jak., sygn. tymcz. ZC-B/14; Kopiaruiusz nr 4.

Uwagi: Znany jedynie z kop. nr 4, fol. 51. Druk: Reg. C. P. Woelky, Regesten, nr 15, s. 593; KBT, s. 8.

1359 (brak dokładnej daty i miejsca)

[Janowie Ald i Jungewiese (bracia Wiese), mieszczanie toruńscy, fundują altarię w kościele parafialnym pod wezwaniem św. Jakuba w Nowym Mieście Toruniu.] Oryg. Perg., rękopis, język niemiecki, wym. 220x315mm.

APT, Dokumenty i listy, nr 1048/1; A. Jak, nr 6 .

Uwagi: Obecnie znajduje sie w APT. Znany też z kop.nr 4, fol. 63; kop. nr 4, fol. 64. Druk: UBC, I, nr 303; Reg. Pr.Ub., Bd. V/2, nr 827, s. 467; C. P. Woelky, Regesten, nr 16, s. 593, KBT, s. 9. 
1360, 19 listopada, Toruń

an send Elysabeth tage

[Winrych von Knieprode, wielki mistrz, poświadcza, że Rada Nowego Miasta Torunia za zgodą ksieni Małgorzaty Gerung i konwentu cysterek-benedyktynek w Toruniu oraz prepozyta klasztornego Mikołaja ufundowała na terenie wolnizny nowomiejskiej kaplicę św. Katarzyny.]

Oryg. Perg., stan dobry, rękopis, język niemiecki.

APT, Dokumenty i listy, nr 66; Scrinium XIV, IX, 5, nr 18.

Uwagi: Do dokumentu jest przywieszona dobrze zachowana pieczęć konwentualna toruńskich cysterek-benedyktynek, Nowego Miasta Torunia, wielkiego mistrza. Druk: UBC, I, nr 303; Reg. C. P. Woelkey, Regesten, nr 17, s. 593; Kat. D.i L.K., t. 1, nr 31, s. 16.

1360 (brak dokładnej daty), Toruń

[Rada Nowego Miasta Torunia poświadcza fundację wikarii przez mieszczanina Piota Schulmeistra w kaplicy św. Katarzyny.]

Oryg. Perg., rękopis, język niemiecki.

APT, kat II, XIV, nr 6.

Uwagi: Druk: UBC, I, nr 307; Reg. C. P. Wo elky, Regesten, nr 18, s. 593; Pr. Ub., Bd. V/2, nr 942, s. 359 .

1370, 18 marca, Toruń

Montag nach Oculi

[Winrych von Knieprode, wielki mistrz, nadaje konwentowi toruńskich cysterekbenedyktynek, w ich posiadłości Kamionki, jezioro Peszke z prawem połowu ryb małymi sieciami.]

Oryg. Perg., stan dobry, rękopis, język niemiecki, wym. 225×190 mm.

APT, Klasztor cysterek-benedyktynek, A. Dokumenty, nr 2; A. Tor. Nr 85; 112.

Uwagi: Druk: UBC, I, nr 325; Reg. C. P. Woelky, Regesten, nr 19, s. 593; Kat. D. i L K, t. 1, nr 37, s. 18.

1373, 24 marca, Rzym

8 Kalendas Aprilis in vigilia Annuntiationis Mariae

[Lukasz Celsi, arcybiskup Rems i generalny wikariusz papieża Grzegorza XI, 
nadaje toruńskim cysterkom-benedyktynkom odpust zupełny w obliczu śmierci penitentki oraz inny na sto lat.]

Oryg. Perg., niezachowany, rękopis, język łaciński.

A. Jak., sygn. tymcz. ZC-B/17; Kopiariusz nr 2.

Uwagi: Znany jedynie z kop. nr 2, fol. 3. Druk: UBC, I, nr 331; Reg. C. P. Woelky, Regesten, nr 20, s. 593; KBT, s. 9.

\section{4}

1381, 8 października, Malbork

Dienstag vor Dionysius

[Elżbieta, ksieni, oraz Elżbieta przeorysza, wraz z całym konwentem cysterek-benedyktynek w Toruniu sprzedają Radzie Nowego Miasta Torunia plac ze wszystkimi budynkami położonymi przy plebanii kościoła św. Jakuba za 1000 grzywien.]

Oryg. Perg., stan dobry, rękopis, język niemiecki, wym. 350x220 mm.

APT, Dokumenty i listy, nr 117, nr 115; Scrinium XIV, nr 28, 39; X, nr 3.

Uwagi: Do dokumentu przywieszone 4 pieczęcie w tym konwentualna i opacka toruńskich cysterekbenedyktynek. Druk: UBC, I, nr 357; Reg. C. P. Woelky, Regesten, nr 21, s. 594; Thorn. Denk., s. 42 .

\section{5}

1382, 27 maja, (brak miejsca)

VI Kalendas Junii

[Zakonnice królewicckic proszą toruńskie cysterki-benedyktynki o zawarcie z nimi wspólnoty modlitewnej.]

Oryg. Perg., do konserwacji, rękopis, język łaciński, wym. 250x247 mm.

A. Jak., nr 7.

Uwagi: Zachowała się także pieczęć konwentualna zakonnic królewieckich. Znany też z kop. nr 2, fol. 4. Druk: UBC, I, nr 361; Reg. C. P. Woelky, Regesten, nr 22, s. 594; KBT, s. 9.

\section{6}

1382, 9 listopada, (brak miejsca)

an send Elysabeth tage

[Łukasz Russe, mieszczanin toruński, zapisuje młynarzowi Nieze włókę ziemi przy młynie, znajdującym się w pobliżu szpitala Św. Ducha w Toruniu.]

Oryg. Perg., rçkopis, język niemiecki.

\section{A. Jak. nr 8.}

Uwagi: Znany jest $z$ kop. $n r$ 4, fol. 52. Druk: UBC, l, nr 362; Reg. C. P. Woelky, Regesten, nr 23, s. 594; KBT, s. 9. 


\section{7}

1384, 27 listopada, Toruń

am nachstin sontage noch sente Catherinen

[Konrad Zoellner, wielki mistrz, rozstrzyga spór między mieszczanami Nowego Miasta Torunia a klasztorem cysterek-benedyktynek w Toruniu, oznaczając granice zespołu klasztornego.]

Kop. Pap., stan dobry, rękopis, język niemiecki, wym. 190x320 mm.

APT, Dokumenty i listy, nr 124, nr 423.

Uwagi: Druk: UBC, I, nr 365; Reg. C. P. Woelky, Regesten, s. 24, s. 594; Kat. D.i L.K, t. 1, nr 41, s. 20 .

\section{8}

1388, (brak dokładnej daty), Chełmno

Sabbato dominica, qua cantatur Indicita occurente (..)

[Siostra Małgorzata oraz zakonnice z klasztoru chełmińskiego zawierają wspólnotę modlitewną $z$ opatką Małgorzatą i toruńskimi cysterkami-benedyktynkami, na prośbę dawnego komtura toruńskiego, Konrada Kalemunt.]

Oryg. Perg., do konserwacji, rękopis, język niemiecki, wym. 320x151+18 mm.

\section{A. Jak. nr 9.}

Uwagi: Fragment pieczęci konwentualnej chełmińskich mniszek. Znany też z kop. mr 2, fol.5.

Druk: UBC, I, nr 379; Reg. C. P. Woelky, Regesten, nr 25, s. 594; KBT, s. 9.

\section{9}

1391, 31 marca, Toruń

feria 6 post Pascha

[Stefan, biskup chełmski i Henryk, wikariusz generalny diccezji włocławskiej, nadają toruńskim cysterkom-benedyktynkom list odpustowy, aby te mogły odbudować swoje spalone budynki klasztorne.]

Oryg. Perg., stan dobry, rękopis, język łaciński, wym. 238x112+24 mm.

ADPel., Diploma et epistolae, KI. Ben. (Toruń) 1; tamże, nr 9; A. Jak. nr 10.

Uwagi: Znany jest też z kop. nr 2, fol. 6. Druk:UBC, I, nr 391; Reg. C. P. Woelky, Regesten, nr 27, s. 595; KBT, s. 9. Zakonnice toruńskie występują w tym dokumencie jako benedyktynki.

1391, 6 sierpnia, Wąbrzeźno

die Transfigurationis Domini

[Mikołaj von Schiffenburg, biskup chełmiński, nadaje toruńskim cysterkom-be- 
nedyktynkom list odpustowy, aby te mogły odbudować swoje spalone budynki klasztorne.]

Oryg. Perg., stan dobry, rękopis, język łaciński, wym. 276x 147+22 mm.

ADPel., Diploma et epistolae, KI. Ben. (Toruń) 2; A. Jak. nr 11.

Uwagi: Znany też z kop. nr 2, fol. 6. Druk: UBC, I, nr 394; Reg. C. P. Woelky, Regesten, nr 27, s. 595; KBT, s. 9. Zakonnice tonuńskic występują w tym dokumencie jako benedyktynki.

1392, 4 kwietnia (brak miejsca)

am tage Ambrossii

[Wolf von Zulnhardt, komtur toruński, poświadcza zapis wiecznego czynszu w wysokości 14 grzywien uczyniony przez Szymona Luterberga, kapelana i pisarza zakonu, na rzecz kościoła Św. Ducha w zamian za codzienną mszę.]

Oryg. Perg., stan dobry, rękopis, język niemiecki, wym. 300x230+25 mm.

APT, Klasztor cysterek-benedyktynek, A. Dokumenty, nr 3; Scrinium XII, nr 2; IX,9; A. Tor. nr 160.

Uwagi: Dwie pieczęcie. Druk: Reg. C. P. Woelky, Regesten, nr 28, s. 595; Kat. D. i L. K., t. 1, nr 60 , s. 28.

1392, 4 kwietnia (brak miejsca) am tage Ambrossii

[Wolf von Zulnhardt, komtur toruński, poświadcza zapis 14 grzywien wiecznego czynszu uczyniony przez Marcina, proboszcza z Kowalewa oraz darowiznę 50 grzywien dokonaną przez Henryka z Piotrkowa, byłego proboszcza w Orzechowie na rzecz kościoła Św. Ducha.]

Kop. Pap., do konserwacji, rękopis, język nieniecki, wym. 220×295 nm.

APT, Klasztor cysterek-benedyktynek, A. Dokumenty, nr 4; Scrinium XIV, nr 28; 9; 14.

Uwagi: Poniżej tekstu rozliczenie $z$ płaconego czynszu. Druk: Kat. D. i L. K., t. 14, nr 61, s. 29.

\section{3}

1393, 2 maja, Toruń

indictione 1, pontificatus Bonifacii IX anno 4

[Jan, biskup z Massy, nuncjusz papieski na Polskę, Prusy, Litwę i Inflanty nadaje toruńskim cysterkom-benedyktynkom list odpustowy na wszystkie większe święta, aby mogły odbudować swoje budynki klasztorne.]

Oryg. nie istnieje, rękopis, język łaciński.

A. Jak., sygn. tymez. ZC-B/17; Kopiariusz nr 2. 
Uwagi: Znany z kop. nr 2, fol. 17. Druk: UBC, I, nr 398; Reg. C. P. Wo elky, Regesten, nr 29, s. 595. Zakounice toruńskie występują w tym dokunencie jako benedyktynki.

\section{4}

1399, 1 sierpnia (brak miejsca)

in die b. Petri ad vincula

[Brat Jan, opat z Pelplina, zawiera z opatką Małgorzatą i toruńskimi cysterkamibenedyktynkami wspólnotę modlitewną.]

Oryg. Perg., stan dobry, rękopis, język laciński, wym. 320x204+46 mm.

ADPel., Diploma et epistolae, KI. Ben. (Toruń) 3; A. Jak., nr 12.

Uwagi: Znany z kop. nr 2, fol. 7. Druk: UBC,I, nr 420; Reg. C. P. Woelky, Regesten, nr 30, s. 595; KBT, s. 10.

\section{5}

1400, 13 grudnia, Rzym

idibus decembris, pontificatus anno XII

[Bonifacy IX, papież, nadaje toruńskim cysterkom-benedyktynkom prawo wyboru spowiednika oraz list spowiedni.]

Oryg. Perg., do konserwacji, rękopis, język łaciński, wym. 500x275+57 mm.

ADPel., Diploma et epistolae, Kl. Ben. (Toruń) 4; tamże nr 13; A. Jak., nr 12.

Uwagi: Znany też $z$ kop. nr 2, fol. 19. Druk: UBC, I, nr 429; Reg. C. P. Woelky, Regesten, nr 31, s. 595. Zakonnice toruńskie występują w tym dokumencie jako benedyktynki.

\section{6}

1403, 4 grudnia, Toruń

am abende sancte Barbare

[Małgorzata Papynne, opatka, i toruński konwent cysterek-benedyktynek mieszkających przy kościele św. Krzyża sprzedaje młyn na rzeczce Łące Tomaszowi Herzefeld i jego potomkom za 29 grzywien i 8 grzywien rocznego czynszu.]

Oryg. zaginiony, rękopis, język niemiecki.

\section{A. Jak., sygn. tymez. ZC-B/17; Kopiariusz nr 4.}

Uwagi: Znany jedynie z kop. nr 4, fol. 53; (łaciński przekład) fol. 54. Druk: UBC, I, nr 443; Reg. C. P. Woelky, Regesten, nr 33, s. 596; KBT, s. 10. Zakonnice toruńskie występują w tym dokumencie jako benedyktynki. 
[1407/1409] (brak dokładnej daty i miejsca)

[Ulryk von Jungingen, wielki mistrz, poleca radzie miasta Torunia dołożenie wszelkich starań, aby Elżbieta Frauwendorff, która została porwana z toruńskiego, klasztoru cysterck-benedyktynek, tam powróciła.]

Pap., do konserwacji, rękopis, język niemiecki, wym. 300x220 mm.

APT, Dokumenty i listy, nr 793; nr 466.

Uwagi: Pieczęć wielkiego mistrza w opłatku.

[1407/1410] (brak dokładnej daty i miejsca)

[Amold Stapel, biskup chełmiński, nadaje urząd prepozyta toruńskich cysterekbenedyktynek, mieszkających za murami miasta Torunia, Michałowi, po ustąpieniu jego porzednika Stefana, na prośbę opatki Małgorzaty Papinne oraz Ulryka von Jungingena, wielkiego mistrza.]

Oryg., język niemiecki.

Uwagi: Dokument niezachowany, znany z formularza. Druk Reg.: A. Kolberg, Ein preussisches Formellbuch., nr 67, s. 314. Zakonnice toruńskie występują w tym dokumencie jako cysterki.

\section{9}

1408 (brak dokładnej daty), Torun

[Ulryk von Jungingen, wielki mistrz, zatwierdza ufundowanie wikarii w kościele św. Jakuba w Nowym Mieście Toruniu przez Towarzystwo Jaszczurcze.]

Oryg., rękopis, język niemiecki.

Uwagi: Znany jedynie z odpisu dokumentu znajdującego się w AP w Królewcu w XIX w. Druk: UBC,I, nr 458; Reg.C. P. Woelky, Regesten, nr 34, s. 596; J. Voigt, Anchang zur Geschichte, s. $310-312$.

40

[1409/1410] (brak dokładnej daty i miejsca)

[Jan Vrowendorp prosi radę miasta Torunia, aby córka Gotka, jego brata, pozostała nadal w klasztorze cysterek-benedyktynek toruńskich.]

Pap., niedatowany, stan dobry, rękopis, język niemiecki, wym. 430x275 mm.

APT, Dokumenty i listy, sygn. 792; nr 3132.

Uwagi: Znak wodny. Pieczęc sygnet. 


\section{1}

1410,16 czerwca, Toruń

[Henryk Heilsberg, biskup warmiński, nadaje toruńskim cysterkom-benedyktynkom odpust, aby mogły odbudować swoje zabudowania klasztorne.]

Oryg. zaginiony, rękopis, język łaciński.

A. Jak., sygn. tymcz. ZC-B/17; Kopiarusz nr 2.

Uwagi: Znany jedynie z kop. nr 2, fol.9. Druk: UBC, I, nr 467; Rcg. C. P. Woclky, Regesten, nr 35, s. 596; KBT, s. 10. Zakonnice wystçpują w tym dokumencic jako benedyktynki.

\section{2}

1410, 24 czerwca, Torun

in die S. Johanis Baptiste

[Arnold Stapel, biskup chelmiński, poświęca kościół św. Krzyża w nowo wybudowanym zespole klasztornym toruńskich cysterek-benedyktynek i nadaje im odpust, aby te mogły pokryć dalsze koszty związane $z$ dokonaną odbudową.]

Oryg. zaginiony, rękopis, język laciński.

A. Jak., sygn. tymcz. ZC-B/17; Kopiariusz nr 2.

Uwagi: Znany z kop. nr 2, fol. 8. Druk: Reg. C. P. Woelky, Regesten, nr 36, s. 596; KBT, s. 10. Zakonnice toruńskic występują w tym dokumencie jako benedyktynki.

\section{3}

1411, 1 czerwca, Toruń

am Montage in den Pfingestheiligen tagen

[Opatka Małgorzata Papine, Krystyna vom Berge, przeorysza, Małgorzata Sundirwikinne, podprzeorysza, $z$ konwentem toruńskich cysterek-benedyktynek proszą poprzez swojego prepozyta Jana Tannenberga Radę Torunia o możliwość kupowania placów przy ulicy Rzeźnickiej.]

Oryg. Perg., stan dobry, rękopis, język niemiecki, wym. 427x209+50mm.

ADPel., Diploma et epistolae, Kl. Ben. (Toruń) 5; F12; A. Jak. nr 12; A. Jak. nr 14.

Uwagi: Znany też z odpisu w kop. nr 4, fol. 65, 66. Druk: UBC, I, nr 472; Reg. C. P. Woelky, Regesten, nr 37, s. 596; KBT, s. 10. Zakonnice toruńskie występują w tym dokumencic jako benedyktynki.

\section{4}

1411, 5 czerwca, Wąbrzé́no

feria 6 ante festum sancte et individue Trinitatis

[Arnold Stapel, biskup chełmiński, poświadcza zapis 12 grzywien czynszu doko- 
nany przez Szymona de Luterberg na rzecz ołtarza św. Katarzyny w szpitalu Św. Ducha i 2 grzywien na rzecz szpitala zamkowego.]

Oryg., do konserwacji, rękopis, język łaciński, wym. 450x225+60 mm.

APT, Szpital Św. Ducha, nr 15; Scrinium IX, nr 10; XIII, nr 2, 4; A.M.Tor. nr 692, 121.

Uwagi: Ślady po pieczęciach. Druk: UBC, I, nr 473; Reg. C. P. Woelky, Regesten, nr 38, s. 596.

1411, 30 września, Chełmża

in die sancti Jeronimi Confessoris

[Arnold Stapel, biskup chełmiński, ze swoją kapitułą zwalnia kanonika Jana Tannenberga $z$ obowiązku rezydowania przy kapitule oraz zezwala mu probostwo u torunskich cysterek-benedyktynek zachować dożywotnio.]

Oryg., rękopis, język łaciński.

ADPel. (Cop. Elshengense), p. 69.

Uwagi: Dokument znany z kop. znajdującego się w Pelpinie (Cop. Elshengense), p. 69. Druk: UBC, I, nr 474. Reg. C. P. Woelky, Regesten, nr 39, s. 596. Zakonnice toruńskie występuja w tym dokumencie jako benedyktynki.

46

1411, 11 listopada, Toruń

indictione 4

[Testament magistra Mikołaja Mockaw, proboszcza kościoła św. Jakuba w Nowym Mieście Toruniu.]

Oryg., rękopis, język łaciński.

Uwagi: Znany jedynie z odpisu z kop. A 78, p. 128, znajdującego się w XIX w. w AP w Królewcu. Druk: UBC, I, nr 475; Reg. C. P. Woelky, Regesten, nr 40, s. 596.

1413, 2 kwietnia, Toruń

in Qadragesima dominica Letare

[Małgorzata Pepynne, ksieni klasztoru cysterek-benedyktynek w Toruniu zapewnia Janowi Vinke, prowincjałowi augustynów-eremitów na Turyngię i Saksonię udział w korzyściach płynących z ich modłów, postów i innych czynności duchowych.]

Oryg. Perg., stan dobry, rękopis, język łaciński, wym. 250x 150+25 mm.

APT, Klasztor cysterek- benedyktynek, nr 1; 399; 1; LIV; 4.

Uwagi: Pieczęć uszkodzona, ale na tyle czytelna, aby stwierdzić że jest identyczna $z$ pieczęcią benedyktynek z 1360 r. Druk: UBC, I, nr 480; Reg. C. P. Woelky, Regesten, nr 41, s. 597. Zakonnice toruńskie występują w tym dokumencie jako cysterki. 


\section{8}

1415, 3 stycznia, Lubawa

[Arnold Stapel, biskup chełmiński, wyznacza dotychczasowemu proboszczowi szpitala Św. Ducha Mikołajowi Rosenau roczną rentę w wysokości 20 grzywien jako jego uposażenie.]

Oryg. zaginiony, rękopis, język łaciński.

A. Jak., sygn. tymez. ZC-B/17; Kopiariusz nr 4.

Uwagi: Znany z kop.nr 4, fol. 76 i nr 9, fol 176. Druk: Reg. C. P. Woelky, Regesten, nr 42, s. 597.

\section{9}

1415, 7 stycznia, Lubawa

[Arnold Stapel, biskup chełmiński, zezwala na prośbę Michała Küchmeistera, wielkicgo mistrza, na przeniesienie toruńskich cysterek-benedyktynek z ich siedziby przy kościele Św. Krzyża do szpitala Św. Ducha.]

Oryg. zaginiony, rękopis, język łaciński.

\section{A. Jak., sygn. tymcz. ZC-B/14; Kopiariusz nr 4 i nr 9.}

Uwagi: Znany jedynie $z$ kop. nr 4, fol. 76-78; nr 9, fol. 177. Druk: UBC, I, nr 489; Reg. C. P. Woelky, Regesten, nr 43; KBT, s. 11. Zakonnice toruńskie występuja w tym dokumencie jako benedyktynki.

\section{0}

1415, 12 września, Toruń

am negsten dornstagk vor Crucis Exaltationis

[Michał Küchmeister, wielki mistrz, dokonuje połączenia dóbr szpitala Św. Ducha $\mathrm{z}$ dobrami klasztoru cysterek-benedyktynek, zachowujac dla siebie prawo patronatu i zlecając klasztorowi opiekę nad chorymi.]

Oryg. Perg., do konserwacji, rękopis, język niemiecki, wym. 700x495+75 mm.

APT, Klasztor cysterek-benedyktynek, A. Dokumenty, nr 11, Scrinium IX, nr 16.

Uwagi: Jest to transumpt kapituły chemińskicj z 28.III.1555. Ponownie transumowany przez Stefana Batorego, 28.VII.1583 roku. Druk: Reg. Kat. D. i L. K., t. 1, nr 131 a, s. 58. Zakonnice toruńskie występują w tym dokumencie jako benedyktynki.

\section{1}

1415, 12 września, Toruń

am negsten dornstagk vor Crucis Exaltationis

[Michał Küchmeister, wielki mistrz, dokonuje połączenia dóbr szpitala Św. Ducha $\mathrm{z}$ dobrami klasztoru cysterek-benedyktynek, zachowując dla siebie prawo patronatu i zlecając klasztorowi opieke nad chorymi.] 
Oryg. Perg., do konserwacji, rękopis, język niemiecki, wym. 475x545+90 mm.

\section{A. Jak, nr 15.}

Uwagi : Pieczęć wielkiego mistrza. Dokument znany też z kop. nr 4, fol. 71-73; kop. nr 9, f. 172. Druk: UBC, I, nr 490; Reg. C. P. Woelky, Regesten, nr 44; KBT, s. 11; Thorn. Denk., s. 38. Zakonnice toruńskie występują $\mathrm{w}$ tym dokumencic jako benedyktynki.

1416, 7 kwietnia, Malbork

[Jan Wallenrod, arcybiskup ryski, nadaje toruńskim cysterkom-benedyktynkom odpust, aby mogły wybudować nowy klasztor przy szpitalu $S$ w. Ducha.]

Oryg., niezachowany, rękopis, język łaciński.

A. Jak, sygn. tymcz. ZC-B/17; Kopiariusz nr 2.

Uwagi: Znany jedynie z kop. nr. 2., fol. 12. Druk: UBC, I, nr 491; Reg. C. P. Woelky, Regesten, nr 45, s. 598; KBT, s. 11.

1416, 8 kwietnia, Malbork

[Henryk von Schauenberg, biskup sambijski, nadaje toruńskim cysterkom-benedyktynkom odpust, aby mogły wybudować nowy klasztor przy szpitalu Św. Ducha.]

Oryg. niezachowany, rękopis, język łaciński.

\section{A. Jak, sygn. tymcz. ZC-B/17; Kopiariusz nr 2.}

Uwagi: Znany jedynie z kop. nr 2, fol. 12-13. Druk: UBC, I, nr 492; Reg. C. P. Woelky, Regesten, nr 46, s. 598; KBT, s. 11.

\section{4}

1417, 28 lutego, Malbork

am Sontage Invocavit

[Michał Küchmeister, wielki mistrz, postanawia, że ofiara ze wsi Zamarte, po odliczeniu 10 grzywien, które proboszcz Jan z Niwy otrzymuje dożywotnio za posługi duszpasterskie, płacone muszą być cysterkom-benedyktynkom z Torunia i Chełmna.]

Oryg. Perg., uszkodzony, rękopis, język niemiecki, wym. 414x241+40 mm.

ADPel., Diploma et epistolae, KI. Ben. (Toruń) 6; tamże EE.

Uwagi: Już na początku XIX w. znajdował się w AD w Pelpline. Druk: UBC, I, nr 503; Reg. C. P. Woelky, Regesten, nr 47, s. 598. 


\section{5}

1419, 19 października, Florencja

[Antoni z Peretti, generał miniorytów, ze swoim całym zakonem zawiera $z$ toruńskimi cysterkami-benedyktynkami wspólnotę modlitewną.]

Oryg., rękopis, język łaciński.

A. Jak., sygn. tymcz. ZC-B/17; Kopiariusz nr 2.

Uwagi: Znany jedynie z kop. nr 2, fol. 13. Druk: UBC, I, nr 514; Reg. C. P. Woelky, Regesten, mr 48, s. 599; KBT, s. 12. Zakonnce toruńskie występuja w tym dokumencie jako benedyktynki.

\section{6}

1425, 24 stycznia, Toruń

am Abunde der Bekerunge Pauli

[Ksieni i przeorysza klasztoru cysterek-benedyktynck poświadczają, że po zburzeniu klasztoru przy kościele Św. Krzyża, wielki mistrz zwrócił im dawny klasztor i szpital Św. Ducha, miasto zaś dało 150 tys. cegieł i plac nad Wisłą pod budowę nowego budynku klasztornego.]

Oryg. Perg., do konserwacji, rękopis, język niemiecki, wym. 490x311+83 mm.

ADPel., Diploma et epistolae, KI. Ben. (Toruń) 7; tamże nr 16; A. Jak., nr 16.

Uwagi: Znany też z kop. nr 4, fol. 87, nr 9, fol. 179. Druk: UBC, I, nr 530; Reg. C. P. Woclky, Regesten, nr 49, s. 599; KBT, s.12. Zakonnice toruńskie występują w tym dokumencie jako benedyktynki.

\section{7}

1425, 24 stycznia, Torun

am Abunde der Bekerunge Pauli

[Ksieni i przeorysza klasztoru cysterck-benedyktynek poświadczaja, że po zburzeniu klasztoru przy kościele Św. Krzyża, wielki mistrz zwrócił im dawny klasztor i szpital Św. Ducha, miasto zaś dało 150 tys. cegieł i plac nad Wisłą pod budowę nowego budynku klasztornego.]

Kop. Pap., stan dobry, rękopis, jçzyk niemiccki, k. 3.

APT, Dokumenty i listy, nr 825.

Uwagi: Zakonnice toruńskie występują w tym dokumencie jako benedyktynki.

58

1426, 10 maja, Rzym

VI Idus maii, Pontificatus anno IX

[Papież Marcin V, zgadza się na przekazanie toruńskim i chełmińskim cysterkom- 
benedyktynkom kaplicy pielgrzymkowej w Zamartem przez wielkiego mistrza Michała Küchmeistra.]

Oryg. zaginiony.

Uwagi: Znany jedynie z transumptu opata Bernarda z Oliwy (UBC, I, nr 548).

59

1429, 4 marca, Oliwa

\section{indictione 7}

[Bernard, opat cystersów z Oliwy, poświadcza bullę papicża Marcina V, w której ten zgadza się na przckazanie toruńskim i chełmińskim cysterkom-benedyktynkom kaplicy pielgrzymkowej w Zamartem przez wielkiego mistrza Michała Küchmeistra.]

Oryg. Perg., do konserwacji, rękopis, język łaciński, wym. 568x555+46 mm.

ADPel., Diploma et epistolae, KI. Ben. (Toruń) 8; tamże nr 17.

Uwagi: Bez pieczęci. Druk: UBC, I, nr 548; Reg. C. P. Woelky, Regesten, nr 50, s. 599. Zakonnice chelmińskie i toruńskie występują $w$ tym dokumencie jako cysterki-bencdyktynki.

1429, 9 maja, Lubawa

[Jan Marienau, biskup chełmiński, po ustapieniu Jana Tannenberga ze stanowiska proboszcza kościoła parafialnego w Nowym Mieście Toruniu, na wniosek przełożonej klasztoru Św. Ducha, mającej patronat nad tym kościołem, powołuje na to stanowisko Michała.]

Oryg. Perg., stan dobry, rękopis, język łaciński, wym. 280x165+35 mm.

APT, Kościól św. Jakuba, nr 1; A.Tor., nr 839; 129; Scrinium IX, 27; XVI, nr 5.

Uwagi: Na pasku pieczęć wystawcy. Druk: UBC, I, nr 550. Reg. Kr. Ub., nr 39; C. P. Woelky, Regesten, nr 51, s. 599.

\section{1}

1430 , listopad (brak dokładnej daty i miejsca)

\section{Landding noch Martini}

[Jan Tannenberg, prepozyt toruńskich cysterek-benedyktynek, zamienia wieś klasztorną Zelgno na Wytrębowice z Hanuszem z Zeelfeldu.]

Oryg. zaginiony, rękopis, język niemiecki.

\section{A. Jak., sygn. tymcz. ZC-B/14, Kopiariusz nr 4.}

Uwagi: Znany jedynie z kop. nr 4, fol. 91. Druk: UBC, I, nr 555; Reg. C. P. Woelky, Regesten, nr 52, s. 600; KBT, s. 12. 


\section{2}

1431, 18 listopada, Toruń am Sontage noch Martini [Jan Tannenberg, prepozyt klasztoru cysterek-benedyktynek, sprzedaje za pozwoleniem opatki Urszuli Suderwikinne, włókę ziemi lub łąki przy młynie w Młyńcu Mikołajowi Steffanssonowi w zamian za czynsz.]

Oryg. Perg., do konserwacji, rękopis, język niemiecki, wym. 160x255+20 mm.

A. Jak., nr 17.

Uwagi: Dobrze zachowana pieczęć prepozyta. Transumowany 5 maja 1582 r. przez radę miasta Grudziądza. Znany z kop. nr 4, fol. 55. Druk: UBC, I, nr 560; Reg. C. P. Woelky, Regesten, nr 53, s. 600; KBT, s.13. Zakonnice toruńskie występują w tym dokumencic jako benedyktynki.

\section{3}

1437, 23 kwietnia, Toruń

indictione 15, Pontificatus Eugenii IV anno 7

[Katarzyna Rubittyne, opatka toruńskich cysterek-benedyktynek sprzedaje łakke i ziemię w Lęgu koło Przysieku aptekarzowi toruńskiemu, Janowi von Alster, za czynsz.]

Perg.Istr. Not, do konserwacji, rękopis, język niemiecki, wym. 359x316+75 mm.

ADPel., Diploma et epistolae, Kl. Ben. (Toruń) 9; A. Jak., nr 18.

Uwagi: Nazwiska części zakonnic klasztoru Św. Ducha. Znany teź z kop. nr 4, fol. 93-95. Druk: UBC, I, nr 562; Reg. C. P. Woelky, Regesten, nr 54, s. 600; KBT, s. 13. Zakonnice toruńskie występują w tym dokumencie jako benedyktynki.

\section{4}

1438, 25 kwietnia, Toruń

an dem tage sancti Marci Ewangeliste

[Katarzyna Rubittyne, opatka toruńskich cysterek-benedyktynek, wraz z jej wspólnota przyjmuje Jana Rubitt oraz jego trzech synów do bractwa modlitewnego.]

Oryg. Perg., zaginiony, rękopis, język niemiecki, wym. 238x149+26 mm.

ADPel., Diploma et epistolae, KI. Ben. (Toruń) 10; A. Jak., nr 19.

Uwagi: Znajdowała się przy nim pieczęć konwentualna zakonnic toruńskich. Druk: UBC, I, nr 564; Reg. C. P. Woelky, Regesten, nr 55, s. 600.

\section{5}

1445, 7 kwietnia, Toruń

indictione 8, pontificatus Eugenii IV anno 15

[Jan von Ast, proboszcz starotoruński, wydaje wyrok polubowny dotyczący spo- 
ru między Janem de Wyda, prepozytem toruńskich cysterek-benedyktynek oraz wdowa po aptekarzu Janie von Alster, w sprawie zwrotu przez nią 70 grzywien długu względem klasztoru.]

Oryg. Inst. Not., stan dobry, rękopis, język taciński, wym. 296×257+87 mm.

ADPel., Diploma et epistolae, KI. Ben. (Toruń) 12;A. Jak., nr 20.

Uwagi: Znany też z kop. nr 4, fol. 96-97. Druk: UBC, I, nr 576; Reg. C. P. Woelky, Regesten, nr 56, s. 600 . Zakonnice toruńskie występują w tym dokumencie jako benedyktynki.

66

1446, 6 stycznia, (brak miejsca)

an der hiligen dreyer konighe tage

[Mikołaj Sleyslaw, Maciej von Gorynstchyn, zapisują obszar cmentarza koście]nego, kościół, plebanię i dwór w Zamartem cysterkom-benedyktynkom z Torunia i Chełmna.]

Oryg. Perg., do konserwacji, rękopis, język niemiecki, wym. 225x136+19 mm.

ADPel., Diploma et epistolae, KI. Ben. (Toruń) 11; tamże F.

Uwagi: Druk: UBC, I, nr 580; Reg. C. P. Woelky, Regesten, nr 57, 600.

1446, 9 kwietnia, Toruń

am Palmsonabende

[Jan de Wyda, prepozyt toruńskich eysterek-benedyktynek, przyjmuje list dłużny złotnika toruńskiego Urbana Winzerera opiewający na 12 grzywien rocznego czynszu zapisanego na jego domu.]

Oryg., rękopis, język niemiecki.

A. Jak., sygn. tymez. ZC-B/ 14; Kopiariusz nr 4.

Uwagi: Znany jedynie z kop. nr 4, fol. 104, 105. Druk: UBC, nr 583; Reg. C. P. Woelky, Regesten, nr 58 , s. 600 .

\section{8}

1447, 29 marca, Malbork

an der Mittwoch nach dem Sontage nach Judica

[Konrad von Erlichhausen, wielki mistrz, rozstrzyga spór między radą Nowego Miasta Torunia a Maciejem Wiese mieszczaninem Starego Miasta Torunia, w sprawie prezenty kapelana i czynszu z kaplicy braci Wiese w kościele św. Jakuba w Toruniu.]

Oryg. Perg., stan dobry, rękopis, język niemiecki, wym. 450x275+75 mm.

APT, Dokumenty i listy, nr 1038; 151, Scrinium XIV, nr, IX, nr 28, 11. 
Uwagi: Druk: UBC, I, nr 586; Reg. C. P. Woelky, Regesten, nr 59, s. 601; Kat. D. i L. K., t. 1, nr 237, s.106. Kopia jego znajduje się także w APT, Dokumenty i listy, nr 1048/2.

\section{9}

[1450], 21 kwietnia, Rzym

XI Klaendas Aprilis, pontificatus Nicolai $V$ anno 4

[Dominik, kardynał, proboszcz bazyliki Św. Krzyża w Jerozolimie, w imieniu papieża nadaje rektorowi Michałowi Nystwantzowi, proboszczowi kościoła św. Jakuba w Nowym Mieście Toruniu na 5 lat specjalne prawa odpuszczania grzechów swoim parafianom.]

Oryg. Perg., stan dobry, rękopis, język łaciński, wym. 320x170+50 mm.

APT, Kościól św. Jakuba w Toruniu, sygn. 2; A. Tor. nr 1275, Scrinium XXXII, nr 10; XI, 19. Uwagi: Druk: Reg. C. P. Woelky, Regesten, nr 60, s. 601; Kr. Ub., nr 118; UBC, I , nr 593.

\section{0}

1451, 17 listopada, Sitno

feria 4 infra octavis b. Martini episcopi

[Jan Maricnau, biskup chełmiński, nadaje Andrzejowi, kapelanowi komtura toruńskiego wikarię w kościele Ś w. Ducha w Toruniu.]

Oryg. Perg., po konserwacji, rękopis, język łaciński, wym. 185x58+10 mm.

APT, Dokumenty i listy, sygn.1293; 2743; 1293; 156; Scrinium XIV, nr 27, XI, nr 13.

\section{1}

1459, 11 kwietnia, Toruń

indictione 7

[Szymon z Głażcjewa, sędzia ziemski chełmiński, zapisuje w testamencie 15 grzywien rocznego czynszu ze wsi Przeczno i wszystkie swoje ruchomości torunskim cysterkom-benedyktynkom.]

Oryg.Perg., stan dobry, rękopis, język łaciński, wym. 423×314+49 mm.

ADPel., Diploma et epistolae, KI. Ben. (Toruń) 13; tamże nr 16; A. Jak. nr 21.

Uwagi: Znany też z kop. nr 4, fol. 98-100; Druk: UBC, II, nr 632; Reg. C. P. Woelky, Regesten, nr 61 , s. 601 ; KBT, s. 13-14. Zakonnice toruńskie występują w tym dokumencic jako benedyktyn$\mathrm{ki}$.

1466, 18 kwietnia, Toruń

am Freitag vor S Georgen 
[Jan Teudenkus i Jan Winter, mieszczanie toruńscy, zgadzają się na spłatę klasztorowi cysterek-benedyktynek toruńskich długu w wysokości 70 grzywien.]

Oryg., rękopis, język niemiecki.

\section{A. Jak., nr 22.}

Uwagi: Pieczęć sekretna miasta. Transumowany w 1488 r. przez radę miasta Torunia. Druk: Reg. C. P. Woelky, Regesten, nr 62 i 65, s. 601.

\section{3}

1473, 13 stycznia, Wrocław

Idibus Ianuarii, Pontificatus Sixti IV anno 2

[Marek, kardynał, patryjarcha Akwilei i legat papieski, nadaje 100 dniowy odpust dla kościoła klasztornego Św. Ducha na prośbę kanonika warmińskiego Wernera von Putten.]

Oryg. Perg., rękopis, język łaciński.

\section{A. Jak., sygn. tymez. ZC-B/ 17; Kopiariusz, nr 2.}

Uwagi: Znany jedynie z kop. nr 2, fol. 14. Druk: UBC, II, nr 670; Reg. C. P. Woelky, Regesten, nr 63 , s. 601 . Zakonnice toruńskie występują w tym dokumencie jako benedyktynki.

\section{4}

1482, 23 grudnia, Toruń

feria 2 post festum Thome s. apostoli

[Rada miasta Torunia transumuje dokument wielkiego mistrza Wernera von Orseln z 1 VI 1328 r., w którym nadano toruńskim zakonnicom wsic Kamionki, Nowy Dwór, Rzcwoń, i Zelgno.]

Oryg. stan dobry, rękopis, język łaciński, wym. 310x265 mm.

APT, Klasztor cysterek-benedyktynek, sygn. 5; A. Tor. Nr 29,102; Scrinium X, 1, XIV, nr 31. Uwagi: Druk: UBC, II, nr 699.

1489, 27 marca, Rzym

Pontificatus Innocenti VII anno 4

[Kardynałowie rzymscy (16) ustanawiaja dla kościoła Św. Ducha poza murami miasta Torunia, odpust wieczysty w wyznaczone dni.]

Oryg. rękopis, język taciński.

\section{A. Jak; sygn. tymcz. ZC-B/ 17; Kopiariusz nr 2.}

Uwagi: Dokument znany jedynie z kop. nr 2, fol. 15. Druk: Reg. C. P. Woelky, Regesten, nr 66, s. $601 ; \mathrm{KBT}, 14$. 
1489, 13 sierpnia, Lubawa

[Stefan z Nidzicy, biskup chełmiński poświadcza toruńskim cysterkom-benedyktynkom wszystkie otrzymane odpusty, a w szczególności nadany przez kardynałów rzymskich (16) 27 II 1489 roku.]

Oryg. rękopis, język łaciński.

\section{A. Jak; sygn. tymez. ZC-B/ 17; Kopiariusz nr 2.}

Uwagi: Znany jedynie z kop. nr 2, fol. 16. Druk: UBC, II, nr 718; Rcg. C. P. Woelky, Regesten, nr 67, s. 602; KBT, s. 14. Zakonnice toruńskie występują w tym dokumencie jako benedyktynki.

1498, 24 października, Rzym

pontificatus Alexandri VI anno 7

[Kardynałowie rzymscy (20) ustanawiają dla kaplicy św. Elżbiety w szpitalu Św. Ducha poza murami miasta Torunia, ufundowanej przez Jana Irreganga, $100 \mathrm{dni}$ odpustu dla wiernych obojga płci, którzy w wyznaczonych dniach odwiedzą kaplicę.]

Oryg. Perg., stan dobry, rękopis, język łaciński, wym. 810x480+13 mm.

APT, Szpital Św. Ducha, sygn. 16; A. Tor. Nr 2609,186; Scrinium, XIV, nr 915.

Uwagi: 19 pieczęci woskowych: kardynałów i późniejsza - biskupa chcłmińskiego, Mikołaja Chrapickego; (brak dwóch pieczęci). Dokument znany z kop. nr 2, fol. 15. Druk: Reg. C. P. Woelky, Regesten, nr 70, s. 602.

\section{8}

1499, 18 lutego, Lubawa

2 feria proxima post Invocavit

[Mikołaj Chrapicki, biskup chełmiński, zatwierdza nadane przez kardynałów rzymskich (20) odpusty dla szpitala Św. Ducha.]

Oryg. Perg., stan dobry, rękopis, język laciński.

APT, Szpital Św. Ducha, sygn. 16; A. Tor. Nr 2609,186; Scrinium, XIV, nr 915.

Uwagi: 19 pieczęci woskowych: kardynałów i późniejsza- biskupa chełmińskiego, Mikołaja Chrapickego; (brak dwóch pieczęci). Dokument znany z kop. nr 2, fol. 15. Druk: UBC, II, nr 742; Reg. C. P. Woelky, Regesten, nr 70 i 72, s. 602.

1500, 31 sierpnia, Toruń die lunae ultima Augusti

[Rada miasta Tounia informuje Mikołaja Chrapickiego, biskupa chełmińskego, że do 
beneficjum ufundowanego przez Szymona Luterberga dodano donację Jana Irreganga, prosi o erygowanie tejże i prezentuje na pierwszego beneficjenta ofiarodawce..] Oryg. Perg., stan dobry, rękopis, język łaciński, wym. 375x270+51 mm.

APT, Klasztor cysterek-benedyktynek, sygn. 6; A. Tor. Nr 2644, 192; Scrinium XII, nr 26; IX, nr 11.

Uwagi: Pieczęć miasta. Druk: UBC, II, nr 748.

\section{0}

1500, 31 sierpnia, Toruń

indiccione 3, pontificatus Alexandri VI anno 9

[Poświadczenie zapisu 12 grzywien wiecznego czynszu na rzecz kościoła Św. Ducha - kaplicy św. Katarzyny, dokonanego przez Szymona Luterberga oraz 19 grzywien wiecznego czynszu zapisanych na ten sam cel przez Jana Irreganga z prawem patronatu rady miasta.]

Oryg., stan dobry, rękopis, język laciński, wym. 340x630.

APT, Klasztor cysterek-benedyktynek, sygn.7, A. Tor. nr 2643,191; Scrinium XIII, nr 4, IX, nr 13.

Uwagi: Druk: UBC, II, nr 747.

\section{1}

1500, 7 lutego, Toruń

[Mikołaj Chrapicki, biskup chełmiński, tansumuje i potwierdza dokumenty: Rady Miasta Torunia dotyczący donacji Ireganga; Wolfa von Czolnhardta dotyczący fundacji Szymona Luterberga.]

Instr. Not., Oryg., stan dobry, rękopis, język łaciński.

APT, Klasztor cysterek-benedyktynek, sygn.8, A. Tor. nr 2645,193; Scrinium XXX, 1, IX, 12, XIII, 2c.

Uwagi: Dokument poświadczony przez notariusza Michała Wolskiego (dotyczy także mianowania Irreganga wikariuszem). Druk: UBC, I, nr 398; UBC, II, nr 747, 478.

\section{2}

1502, 26 czerwca, Wrocław

[Krystyna Steinbrucker, opatka, oraz cysterki-benedyktynki toruńskie, otrzymują uczestnictwo dóbr duchowych od Wiktoryna z Prus, wikarego fanciszkańskiego, w imieniu jego zakonu.]

Kop., rękopis, język łaciński.

A. Jak., sygn. tymez. ZC-B/ 17; Kopiariusz nr 2.

Uwagi: Znany jedynie z kop. nr 2, fol.28. Druk: Reg. C. P. Woelky, Regesten, nr 73, s. 602; KBT, s. 14. 


\section{3}

1504, 15 listopada, Toruń

JJan Steyner, wychowawca ze Stcinau (Kamionek) oraz magister i przeor Szpitala Św. Ducha w Kottbus Jakub z Prus, zawierają z Angelicą Skrobin, opatką i toruńskimi cysterkami-benedyktynkami bractwo duchowe.]

Oryg. Perg., do konserwacji, rękopis, język taciński, wym. 318x418+55 mm.

ADPel., Diploma et epistolae, KI. Ben. (Toruń) 14; A. Jak., nr 23.

Uwagi: Lista nazwisk okolo pięćdziesięciu zakonnic. Znany też z kop. nr 2, fol. 29-31. Druk: UBC, II, nr 766; Reg. C. P. Woelky, Regesten, nr 74, s. 602; KBT, s. 602.

\section{4}

[1505] (brak dokładnej daty i miejsca)

[Angelika Skrobin, ksieni kasztoru cysterek-benedyktynek toruńskich, z całą swoją wspólnotą przyjmuje do uczestnictwa w dobrach duchowych Mikołaja Chrapickiego, biskupa chełmińskiego.]

Oryg. Perg., zaginiony, rękopis, język łaciński.

Uwagi : Znany jedynie z KBT, s. 15. Druk: Reg.: tamże.

\section{5}

1507, 30 czerwca, (brak miejsca)

am Donnerstag vor Visitationis Mariae

[Jan, Łukasz i Fryderyk Racken zapisują toruńskim cysterkom-benedyktynkom 50 grzywien czynszu na Czystochlebiu.]

Oryg. zaginiony, rękopis.

A. Jak., sygn. tymez. ZC-B/ 14; Kopiariusz nr 4.

Uwagi: Znany z kop. nr 4, fol. 110. Druk: Reg. C. P. Woelky, Regesten, nr 75, s. 603; KBT, s. 15.

\section{6}

1509, 31 marca, Piotrków

Sabbato ante Palmarum

[Król Zygmunt I, zezwala toruńskim cysterkom-benedyktynkom na wykup zastawionych u Rady Miasta Torunia młynów królewskich.]

Oryg., zaginony, rękopis.

\section{A. Jak., sygn. tymcz. ZC-B/ 14; Kopiariusz nr 4.}

Uwagi: Znany jedynie z kop. nr 4, fol. 111. Druk: Reg. C. P. Woelky, Regesten, nr 76, s. 603; KBT, s. 15. 


\section{7}

1510, 25 maja, Toruń

Sabbato in vigilia sancte Trinitatis

[Rada Miasta Torunia poświadcza, że pani Jadwiga Langhausinne przekazała klasztorowi cysterek-benedyktynek w Toruniu 13,5 włóki ziemi w Przecznie.]

Oryg., zaginiony, rękopis, język nicmiecki.

A. Jak., sygn. tymez. ZC-B/ 14; Kopiariusz nr 4.

Uwagi: Znany jedydnie z kop. nr 4, fol. 114. Druk: Reg. C. P. Woclky, Regesten, nr 77, s. 603.

\section{8}

\section{3, 12 stycznia, Toruń}

[Brat Baptysta z Austrii, franciszkanin i komisarz papieski, nadaje toruńskim cysterkom-benedyktynkom pozwolenie, aby Najświętszy Sakrament mogły przechowywać w monstrancji.]

Oryg., zaginony, rękopis, język łaciński.

\section{A. Jak., sygn. tymcz. ZC-B/ 17; Kopiariusz nr 2.}

Uwagi: Znany jedynie z kop. nr 2, fol. 32. Druk: UBC, II, nr 794; Reg. C. P. Woelky, Regesten, nr 78, s. 603; KBT, s. 17. Zakonnice toruńskie występują w tym dokumencie jako benedyktynki.

\section{9}

\section{3, 1 marca, Poznań}

feria 3 post Oculi, regni anno 7

[Zygmunt I, król polski, nakazuje wojewodzie chelmińskiemu, Janowi z Dąbrowy oraz toruńskim rajcom, aby w jego imieniu sprawę sporną między klasztorem cysterek-benedyktynek toruńskich a kasztelanem chelmińskim Arnoldem von Francza, rozstrzygnęli zgodnie z prawem.]

Oryg. Perg., rękopis, język łaciński.

\section{A. Jak., sygn. tymez. ZC-B/ 14; Kopiariusz nr 4.}

Uwagi: Znany jedynie z kop. nr 4, fol. 115. Druk: Reg. C. P. Woelky, Regesten, nr 79, s. 603; KBT, s. 17.

\section{0}

\section{3, 2 maja, Poznań}

feria 2 ipso die festi S. Sigismundi, regni anno 7

[Zygmunt I, król polski, poleca biskupowi Janowi Konopackiemu i wojewodzie chełmińskiemu Mikołajowi Dąbrowskiemu, załagodzić spór klasztoru cysterekbenedyktynek toruńskich z braćmi Janem i Stanisławem Szczawińskimi o jezioro Mlewiec i prawo połowu ryb na korzyść zakonnic.] 
Oryg. Perg., rękopis, język łaciński.

\section{A. Jak., sygn. tymcz. ZC-B/ 14; Kopiariusz nr 4.}

Uwagi: Znany jedynic z kop. nr 4, fol. 116. Druk: C. P. Woelky, Regesten, nr 80, s. 604; KBT, s. 17.

\section{1}

1513, 10 czerwca, Nowy Dwór.

feria 6 ante Viti et Modesti

[Jan Konopacki, biskup chełmiński i Jan Dąbrowski, wojewoda chełmiński, rozstrzygają na korzyść cysterek-benedyktynek toruńskich spór pomiędzy braćmi Szczawińskimi o prawo połowu ryb na jeziorze Mlewiec.]

Oryg. Perg., stan dobry, rękopis, język łaciński, wym. 320x165+45 mm.

APT, Klasztor cysterek-benedyktynek, sygn. 9; A. Tor., nr 2810; Scrinium XX, nr (4), 5.

Uwagi: Znany też z kop. nr 4, fol.116. Druk: UBC, II, nr 795; Reg. C. P. Woelky, Regesten, nr 81, s. $604 ;$ KBT, s. 17.

[1517-1519] (brak dokładnej daty i micjsca)

[Angelica Scrobin, opatka, Magdalena Hockienne, przeorysza i cały konwent cysterek-benedyktynek w Toruniu zawiadamiają sędziów i ławników miasta Torunia, że upoważniają Jana Lisemana do zastępowania Barbary Adamynne przed sądem podczas toczącego się podziału jej spadku.]

Pap., do konserwacji, rękopis, język niemiecki.

APT, Dokumenty i listy, sygn. 2919; 1001 C.

93

1518, 17 sierpnia, Kraków

feria 3 post Assumptionis Mariae

[Zygmunt I, król polski nakazuje toruńskim cysterkom-benedyktynkom, aby te oddały Radzie Miasta Torunia czwartą część młynów królewskich, które trzymały jako zastaw.]

Oryg., rękopis, język łaciński.

A. Jak., sygn. tymcz. ZC-B/ 14; Kopiariusz nr 4.

Uwagi: Znany jedynie z kop. nr 4, fol. 119. Druk: Reg. C. P. Woelky, Regesten, nr 83, s. 604; KBT, s. 17. 


\section{4}

1518, 22 września, Toruń

[Brat Baptysta z Austrii, franciszkanin, oraz nuncjusz papieski Krzysztof de Forlivio, nadają toruńskim cysterkom-benedyktynkom liczne przywileje duchowne np. zupcłne rozgrzeszenie raz w życiu i drugi raz w obliczu śmierci penitentki.] Oryg., rękopis, język laciński.

\section{A. Jak., sygn. tymez. ZC-B/ 17; Kopiariusz nr 2.}

Uwagi: Znany jedynie z kop. nr 2, fol. 33-35. Lista nazwisk zakonnic toruńskich. Druk: UBC, II, nr 814; Reg. C. P. Woelky, Regesten, nr 84, s. 604, KBT, s. 17. Zakonnice toruńskic występują w tym dokumencie jako benedyktynki.

1519, 18 lutego, Piotrków

[Klasztor toruńskich cysterek-benedyktynek poprzez swego prepozyta Pawła Lymberga, zawiera ugodę $\mathrm{z}$ Janem Bochotnickim, kasztelanem wiślickim oraz Andrzejem Duninem, starostą bolesławskim i brzeźnickim w sprawie spadku toruńskiej zakonnicy, Katarzyny Duninówny.]

Kop., rękopis, język łaciński.

\section{A. Jak., sygn. tymez. ZC-B/ 14; Kopiariusz nr 4.}

Uwagi: Znany jedynie z kop. nr 4, fol. 122. Druk: C. P. Woelky, Regesten, nr 85, s. 605; KBT, s. 18.

1523, 19 sierpnia, Toruń am Mittwoch nach Assumptionis Marie

[Burmistrz i Rada Miasta Torunia, poświadczają że w 1507 r. bracia Racken darowali konwentowi toruńskich cysterek-benedyktynek 50 grzywien zapisanych na Czystochlebiu.]

Oryg., rękopis, język niemiecki.

\section{A. Jak., sygn. tymcz. ZC-B/ 14; Kopiariusz nr 4.}

Uwagi: Znany jedynie z kop. nr 4, fol. 110.Druk: UBC, II, nr 824; Reg. C. P. Woclky, Regesten, nr 86, s. 605; KBT, s. 18.

1524, 17 grudnia, Toruń

Sonnabend nach Lucia

[Władze miejskie /nazwiska urzędników/ pożyczają od cysterek-benedyktynek 
mieszkających przy kościele Św. Ducha w Toruniu 400 grzywien na budowę składu popiohu i smoty.]

Pap. Bifol., stan dobry, rękopis, język niemiecki, wym. 210×335 mm.

APT, Klasztor tysterek-benedyktynek, sygn. 10; A.Tor., nr 2949, 209.

Uwagi: Druk: Reg. C. P.Woelky, Regesten, nr 87, s. 605; KBT, s. 18.

\section{8}

1526, 14 czerwca, Gdańsk

feria 5 post festum $S$. Antonii, regni anno 20

[Zygmunt I, król polski, prolonguje legat Jakubowi Rokuszowi na dobra i wsie:

Dźwierzno, Zajączkowo, Ostrów, Oczyn i połowę Zelgna.]

Oryg., rękopis, język łaciński

A. Jak., nr 29.

Uwagi: Transumpt: 26 I 1622 r. Druk: Reg. C. P. Woelky, Regesten, nr 88, s. 605.

99

1528, 24 czerwca, Torun

Freitage vor Jacobi

[Jan Konopacki, biskup chełmiński, zezwala zakonnicy Barbarze Strobanth pozostać w klasztorze toruńskich cysterek-benedyktynek i nie stosować żadnych dodatkowych i wyczerpujacych ją umatwień oraz na przyjęcie ustanowionej przez jej brata sumy 100 grzywien w postaci czynszu.]

Oryg., rękopis, język niemiecki.

A. Jak., sygn. tymcz. ZC-B/ 14; Kopiariusz nr 4.

Uwagi: Znany jedynie z kop.nr 4, fol. 126, 127. Druk: UBC, II, nr 843; Reg. C. P. Woelky, Regesten, nr 89, s. 605; KBT, s. 18.

\section{0}

1528, 4 grudnia, Żnin

feria 6 ipso die divae Barbarae

[Katarzyna Orłowa, wdowa po Janie Orzeł, zeznaje, że jej mąż sprzedał 14 włók ziemi w Przecznie i że matka jego pierwszej żony, nieżyjąca Katarzyna Kaszka miała $z$ nich $w$ dożywociu dwa łaszty żyta, które po jej śmierci miały być znów oddawane do klasztoru toruńskich cysterek-benedyktynek.]

Język niemiecki.

A. Jak., sygn. tymez. ZC-B/ 14; Kopiariusz nr 4.

Uwagi: Znany jedynie z kop. nr 4, fol. 118. Druk: Reg. C. P. Woelky, Regesten, nr 90, s. 605. 


\section{1}

1528,21 grudnia, Stara Nieszawa

feria 2, die $S$. Thomas

[Dwóch mieszczan ze Starej Nieszawy, zeznaje, że nieżyjący Piotr Targacz ze swoją żoną twierdzili, iż Katarzyna Kaszka wielokrotnie mówila im o tym że, miała sprzedać klasztorowi toruńskich cysterek-benedyktynek 13,5 włóki ziemi w Przecznie, które posiadała dożywotnio.]

Język niemiecki.

A. Jak., sygn. tymez. ZC-B/ 14; Kopiariusz nr 4.

Uwagi: Znany jedynie z kop. nr 4, fol. 117. Druk: Reg. C. P. Woelky, Regesten, nr 91, s. 606.

102

\section{5, 5 czerwca, Chełmno}

Sonnabend vor Barnabas Apostoli

[Jan Hase z Chełmna, tamtejszy mieszczanin i piekarz, pożycza od klasztoru cysterek-benedyktynek toruńskich 50 grzywien pod zastaw swojego domu, z którego będzie płacił klasztorowi czynsz w wysokości 4 grzywien rocznie.]

Język niemiecki.

A. Jak., sygn. tymez. ZC-B/ 14; Kopiariusz nr 4.

Uwagi: Znany jedynie z kop. nr 4, fol.130. Druk: Reg. C. P. Woelky, Regesten, nr 92, s. 606.

\section{3}

1538, 29 lipca, Toruń

[Toruńscy rajcy pośredniczą $w$ umowie pomiędzy pancm Pawłem Lymbergiem i zarządcą toruńskich cysterek-benedyktynek, Adamem Firwal, na sumę 100 grzywien, którą zakonnica Zofia Warienczky w 1509 r. otrzymała i którą Lymberg zatrzymał razem $z$ czynszem $w$ dożywociu.]

A. Jak., sygn. tymcz. ZC-B/ 14; Kopiariusz nr 4.

Uwagi: Znany jedynie z kop. nr 4, fol. 112,113. Druk:Reg. C. P. Wo elky, Regesten, nr 93, s. 606.

104

1551, 28 stycznia, Toruń

[Anna Grossine, opatka i konwent toruńskich cysterek-benedyktynek zapisują rajcy Janowi Strobandowi młyn na rzeczce Łące i 3 włóki ziemi w Brzezinku.]

Oryg. Perg., do konserwacji, rękopis, język niemiecki, wym. 583x716+56 mm..

ADPel., Diploma et epistolae, KI. Ben. (Toruń) 15; Jak., nr 24. 
Uwagi: Druk: UBC, II, nr 1004; Reg. C. P. Woelky, Regesten, nr 94, s. 606. Zakonnice toruńskie występują w tym dokumencie jako benedyktynki.

\section{5}

[1554] (brak dokładnej daty i miejsca)

[Zygmunt August, król polski, nakazuje toruńskim cysterkom-benedyktynkom, aby te oddały miastu Toruń przywileje na przechowanie.]

Oryg., rękopis, język łaciński.

ADPel., Kronika benedyktynek toruńskich.

Uwagi: Znany jedynie z Druk: Reg. KBT, s. 19.

\section{6}

1555, 7 maja, Piotrków

feria 3 in vigilia sancti Stanislai

[Zygmunt August, król polski, powołuje Jana ze Służewa, kasztelana śremskiego na kuratora i prowizora klasztoru cysterek-benedyktynck w Toruniu oraz szpitala $\mathrm{z}$ zaleceniem zarządzania ich majątkiem oraz odzyskaniu tego co zostało utracone.]

Oryg. Perg., stan dobry, rękopis, język łaciński, wym. 555x255+10 mm.

APT, Klasztor cysterek-benedyktynek, sygn. 12; Scrinium X, nr 11; XX; A.Tor., nr 3003, 214. Uwagi: Druk: Reg. C. P. Wo elk y, Regesten, nr 95, s. 606; Kat. Dok. i L. Król., nr 278, s. 140.

\section{7}

1555, 28 marca, Chełmża

die Joviis post festum Annunciationis Mariae

[Kapituła chełmińska potwierdza przez transumpt dokument Michała Küchmeistrạ z 12 IX 1415 r., w którym tenże połączył dobra szpitala Św. Ducha z klasztornymi zachowując dla siebie prawo patronatu i zlecając klasztorowi opiekę nad chorymi.]

Oryg. Perg., rękopis, łaciński, niemiecki, wym. 700x495+75 mm.

APT, Klasztor cysterek-benedyktynek, sygn. 11; A. Tor., nr 3006a; nr 4.

Uwagi: Pieczęć kapituły.

\section{8}

[1555] (brak dokładnej daty i miejsca)

[Zygmunt August, król polski, nakazuje toruńskim cysterkom-benedyktynkom wydać miastu Toruń przywilej (Michała Küchmeistra) na przechowanie, wobec 
stanowiska biskupa chelmińskiego uważającego, że powinien się on raczej znaleźć w archiwum kapituły.]

Oryg., rękopis, język łaciński.

Uwagi: Znany jedynie z Druk: Reg. KBT, s. 19.

\section{9}

1559, 7 stycznia, Piotrków

sabbato post festum Trium Regum

[Zygmunt August, król polski, po rezygnacji Jana ze Służewa, wojewody inowrocławskiego z zarządzania dobrami klasztoru cysterek-benedyktynek i szpitala Św. Ducha w Toruniu, przekazuje administrację majątkiem i klasztorem władzom miasta Torunia.]

Oryg., stan dobry, rękopis, język laciński, wym. 695x385 mm.

APT, Dokumenty i listy, sygn. 3009; Scrinium, X, nr 12.

Uwagi: Znany jedynie z Druk: Reg. KBT, s. 1; C. P. Woelky, Regesten, nr 97, s. 607; Kat. D. i L. Król., nr 283, s. 143.

110

1582, 14 maja, Toruń

indictione 10

[Elżbieta Krowicka, zakonnica toruńska, zeznaje przed notariuszem publicznym przysłanym do niej przez biskupa Piotra Kostkę o dawnych posiadlościach i prawach klasztoru cysterek-benedyktynek toruńskich pod wezwanicm Św. Ducha.] Inst. Not., rękopis, język laciński.

A. Jak., sygn. tymcz. ZC-B/ 14; Kopiaiusz nr 4.

Uwagi: Znany jedynie z kop. nr. 4, fol. 151-153. Druk: UBC, II, nr 1092; Reg. C. P. Woelky, Regesten, nr 100, s. 607; KBT, s. 24-25.

\section{1}

1583, 2 sicrpnia, Kraków

feria 6 ante Transfigurationis Domini

[Stefan Batory, król polski, po zapoznaniu się z przywilejem Michała Küchmeistra, postanawia znów rozdzielić dobra klasztorne i szpitalne, przyznając prepozytowi toruńskich cysterek-benedyktynek Walentemu Wróblewskiemu zarząd majątkiem klasztoru, a miastu szpitala.]

Oryg. Perg.Dwustr., rękopis, język laciński, wym. 560x280+95 mm.

APT, Dokumenty i listy, sygn. 3024; 217; 2648; Scrinium, X, 13; XX, nr 4.

Uwagi: Druk: Reg. C. P. Woclky, Regesten, n 101, s. 607; Kat. D. i. L. Król., nr 300, s. 152-153;

KBT, s. 26. 


\section{2}

1583, 28 sierpnia, Kraków

[Stefan Batory, król polski, transumuje przywilej wielkiego mistrza Michała Küchmeistera z 12 IX 1415 r. dotyczącego połączenia dóbr szpitala Św. Ducha $\mathrm{i}$ istniejącego przy nim klasztoru cysterek-benedyktynck zachowując dla siebie prawo patronatu.]

Oryg. Perg., stan dobry, rękopis, język laciński, niemiecki, wym. 600x550+70 mm.

APT, Klasztor cysterek-benedyktynek, sygn. 13; A.Tor., nr 3025; 218; Scrinium XX, nr 1, 9, 16; XI, nr1.

Uwagi: Druk: Reg. C. P. Woelky, Regesten, nr 102, s. 607; Kat. D. i L. Król., nr 301, s. 153. Zakonnice toruńskie występują w tym dokumencie jako benedyktynki.

\section{3}

1585,19 stycznia, Lubawa

[Rada Miasta Lubawy transumuje na wniosek Jerzego Schurit, sekretarza Piotra Kostki, biskupa chełmińskiego, dwa dokumenty biskupa chełmińskiego Arnolda Stapela, z 3 i 7 I 1415 r.]

\section{A. Jak., Kopiariusz nr 4.}

Uwagi: Znany jedynie z kop. nr 4, fol. 75-78. Druk: Reg. C. P. Woelky, Regesten, nr 103, s. 607.

\section{4}

1593, 23 kwietnia, Warszawa

feria 6 ante dominicam Conductus Paschae

[Zygmunt III Waza, król polski, przysądza toruńskim cysterkom-benedyktynkon dobra szpitala Św. Ducha, nakazując Radzic Miasta Torunia ich wydanie.]

Oryg., rçkopis, język łaciński.

\section{A. Jak. nr 27.}

Uwagi: Znany jako transumpt wydany w 1603 r. Druk: Reg. C. P. Woelky, Regesten, ur 105, s. 608; KBT, s. 37.

\section{5}

1596, 24 czerwca, Toruń

[Piotr Tylicki, biskup chełmiński, nadaje starszej klasztoru cysterek-benedyktynek toruńskich, Zofii Dulskiej, dwa pozwolenia na rozmowy z rzemieślnikami pracującymi w klasztorze, odwiedziny krewnych mniszek oraz przyjmowanie nowicjuszek do klasztoru.]

Oryg., rçkopis, język łaciński.

A. Jak., sygn. tymcz. ZC-B/ 17; Kopiariusz nr 2. 
Uwagi: Znany jedynie z kop. nr 2, fol. 54. Druk: Reg. UBC, II, nr 1107; C. P. Woelky, Regesten, nr 170 , s. 608.

\section{6}

1598, 16 lipca, Chełmża

feria 5 post Divisionis Apost.

[Klasztor toruńskich cysterek-benedyktynek kupuje dom położony w wiosec rybackiej koło Tounia, na klasztornym gruncie, za 130 guldenów.]

\section{A. Jak., sygn. tymcz. ZC-B/ 14; Kopiariusz nr 4.}

Uwagi: Znany jedynie z kop. nr 4, fol. 144-146. Druk: Reg. C. P. Woelky, Regesten, nr 108, s. 608.

\section{7}

1599, 4 sierpnia (brak miejsca)

[Zofia Dulska, opatka klasztoru cysterek-benedyktynek toruńskich, godzi się z Radą Miasta Torunia w sprawie jeziora Mlewiee koło Nowego Dworu.]

Oryg., rękopis.

APT, kat. II, X., k. 6-7.

Uwagi: Druk: Reg. C. P. Woelky, Regesten, nr 110, s. 608.

\section{8}

1599, 14 sicrpnia, (brak miejsca)

Tag vor dem Fest der h. Mariae (sic!)

[Maciej Konopacki, podkomorzy, Odinet Perenot, kanonik i administrator chełmiński nakazują radzie miasta Torunia wydać wszystkie dokumenty toruńskich cysterek-benedyktynek, które zwróciły się o odszkodowanie za niczwrócone przywileje do króla.]

Uwagi: Znany jedynie z Druku: Thor. Denk., fol. 48-51; Reg. C. P. Woelky, Regesten, nrr 111, s. 609 .

\section{9}

\section{9, 3 września, Toruń}

[Zofia Dulska, opatka toruńskich cysterek-benedyktynek, kwituje otrzymanie 500 grzywien od Rady Miasta Torunia.]

Oryg., rękopis.

APT, kat. II, X., 14.

Uwagi: Druk: Reg. C. P. Woelky, Regesten, nr 112, s. 609. 


\section{0}

1599, 4 września, (brak miejsca)

[Zofia Dulska, opatka toruńskich cysterek-benedyktynek, kwituje otrzymanie zwrotu dhugu od Rady Miasta Torunia.]

Oryg., reckopis.

APT, kat. II, X. 9.

Uwagi: Druk: Reg. C. P. Woclky, Regesten, nr 113, s. 609.

\section{1}

1599, 17-18 października, (brak miejsca)

[Franciszek Łancki, biskup margaryteński, sufragan włocławski, święci w kościele Św. Ducha wielki ołtarz i portalia ołtarzy małych za pozwoleniem biskupa chełmińskiego Piotra Tylickiego.]

Oryg., rękopis, język łaciński.

A. Jak., sygn. tymcz. ZC-B/ 17; Kopiariusz nr 2.

Uwagi: Znany jedynie z kop. nr 2, fol. 47-48. Druk: Reg. C. P. Woelky, Regesten, nr 114, s. 609; KBT, s. 45.

\section{2}

1600, 12 września, Warszawa

[Piotr Tylicki, biskup chełmiński, zezwala Zofii Dulskiej, opatce toruńskiej na przyjmowanie kandydatek do klasztoru na rok w budyku panien świeckich i innych pomieszczeniach poza klauzurą.]

A. Jak., sygn. tymcz. ZC-B/ 17; Kopiariusz nr 2.

Uwagi: Znany tylko z kop. nr 2, fol. 65. Druk: Reg. C. P. Woelky, Regesten, nr 115, s. 609.

\section{3}

\section{0, 12 września, Warszawa}

[Piotr Tylicki, biskup chełmiński, wydaje Zofii Dulskiej, opatce toruńskich cysterek-benedyktynek zezwolenie na jeden rok, aby ta mogła w towarzystwie profesck w celu inspekcji dóbr klasztornych lub wyjazdu na rozprawy sądowe opuszczać klasztor.]

A. Jak., sygn. tymez. ZC-B/ 17; Kopiariusz nr 2.

Uwagi: Znany jedynie z kop. nr 2, fol. 56. Druk: Reg. C. P. Woclky, Regesten, nr 116, s. 609. 


\section{4}

\section{0, 12 września, Warszawa}

[Piotr Tylicki, biskup chełmiński, zezwala Zofii Dulskiej i całemu konwentowi cysterek-benedyktynck podczas zarazy opuścić klasztor i zamieszkać w bezpiecznym miejscu.]

Oryg., rękopis, język polski.

A. Jak., sygn. tymcz. ZC-B/ 17; Kopiariusz nr 2.

Uwagi : Znany jedynie z kop. nr 2, fol. 56. Druk: Reg. C. P. Woclky, Regesten, nr 117, s. 609; KBT, s. 46.

\section{5}

1601, 23 lutego, Chełmża

[Odynet Perenoth, kanonik chełmiński, nadaje Zofii Dulskiej, opatce toruńskiej i całemu zgromadzeniu cysterek-benedyktynek przywilej nie przyjmowania rozkazów od osób nie mających upoważnienia biskupa chełmińskicgo oraz przywilej zachowywania starej reguły tego konwentu.]

A. Jak., sygn. tymcz. ZC-B/ 17; Kopiariusz nr 2.

Uwagi: Znany jedynie z kop. nr 2, fol. 57. Druk: Reg. C. P. Woelky, Regesten, nr 118, s. 610.

\section{6}

1601, 3 marca, Warszawa

Regnorum nostrorum Pololoniae XIV, Sueciae VII.

[Zygmunt III, król polski, transumuje i zatwierdza dokument Ludolfa Königa, wielkiego mistrza z 1345 r., dotyczący nadania kościoła parafialnego pod wezwaniem św. Jakuba w Toruniu cysterkom-benedyktynkom.]

Oryg. Perg., rękopis, język łaciński.

\section{A. Jak., nr 25.}

Uwagi: Znany z kop. nr 4, fol. 35-36. Druk: Reg. C. P. Woelky, Regesten, nr 119, s. 610; Thorn. Denk., s. 53. Zakonnice toruńskie występują̨ w tym dokumencie jako benedyktynki.

\section{7}

1601, 6 lipca, Brodnica

[Zygmunt III, król polski, tansumuje i zatwierdza na prośbę Zofii Dulskicj, opatki toruńskich cysterek-benedyktynek, dokument Wenera von Orseln., wielkiego mistrza, dotyczący prawa patronatu nad kościołem parafialnym w Szynwałdzie.]

\section{A. Jak., sygn. tymcz. ZC-B/ 14; Kopiariusz nr 4.}

Uwagi: Znany jedynie z kop. nr 4, fol. 21-22. Druk: Reg. C. P. Woelky, Regesten, nr 120, s. 610. 


\section{8}

1603, 18 marca, Kraków

feria 3 post Judaica

[Zygmunt III, król polski, skazuje Radę Miejską w Toruniu na wydanie wszystkich zabranych cysterkom-benedyktynkom przywilejów.]

Oryg. Perg., do konserwacji, rçkopis, język taciński, wym. 592x316+10 mm.

ADPel., Diploma et epistolae, Kl. Ben. (Toruń) 16; Jak., ur 26.

Uwagi: Pieczęć wystawcy. Druk:UBC, II, nr 1120; Reg. C. P. Woel ky, Regesten, nr 122, s. 610.

\section{9}

1603, 20 marca, Kraków

feria 5 ante Palmarum

[Zygmunt III, król polski, zatwierdza swój wyrok z 1593 r., w sprawie wydania toruńskim cysterkom-benedyktynkom dóbr szpitalnych.]

Oryg. Perg., do konscrwacji, rçkopis, język laciński, wym. 630x416+74 mm.

ADPel., Diploma et epistolae, Kl. Ben. (Toruń) 17; A. Jak, nr 27.

Uwagi: Pieczęć wystawcy. Druk: UBC, II, nr 1121; Reg. C. P. Woelky, Regesten, nr 123, s. 610.

\section{0}

1606, 1 sicrpnia, Bobrowno

feria 3 ipso die Petri in vinculis

[Paweł Działyński, starosta radzyński, pożycza od klasztoru cysterek-benedyktynek toruńskich 10.000 pol. gulden., które zakonnice otrzymały jako odszkodowanie od miasta Toruń, w zamian za czynsz płacony do klasztoru, w wysokości 600 pol. gulden. rocznie i pod zastaw swoich dóbr.]

\section{A. Jak., sygn. tymcz. ZC-B/ 14; Kopiariusz nr 4.}

Uwagi: Znany jedynie z kop. nr 4, fol. 155-156. Druk: Reg. C. P. Woelky, Regesten, nr 124, s. 611; KBT, s. 53.

\section{1}

1606, 28 sierpnia, Gniezno

feria 2 post festum s. Bartolomei Apostoli

[Urząd w Gnieźnie, uznaje zastaw części Wrześni przez Pawła Działyńskiego w zamian za pożyczkę u toruńskich cysterek-benedyktynek.]

\section{A. Jak., sygn. tymcz. ZC-B/ 14; Kopiariusz nr 4.}

Uwagi: Znany jedynie z kop. nr 4, fol. 157. Druk: Reg. C. P. Woelky, Regesten, nr 125, s. 611. 


\section{2}

1609, 26 marca, (brak miejsca)

[Klasztor toruńskich cysterek-benedyktynek odkupuje młyn Bierzgieł.]

A. Jak., sygn. tymcz. ZC-B/ 14; Kopiariusz nr 4.

Uwagi: Znany z kop. nr 4, fol 58. Druk: Reg. C. P. Woelky, Regesten, nr 126, s. 611; KBT, s. 56.

\section{3}

1609, 27 maja, Kraków

Regnorum nostrorum Poloniae XXII, Sueciae XV.

[Zygmunt III Waza, król polski, zezwala na zastawienie w klasztorze toruńskich cysterek-benedyktynek części Wrześni i innych dóbr Pawłowi Dzialyńskiemu.]

A. Jak., sygn. tymcz. ZC-B/ 14; Kopiariusz nr 4.

Uwagi: Znany jedynie z kop. nr 4, fol. 157-158. Druk: Reg. C. P. Woelky, Regesten, nr 127, s. 611 .

1609, 24 lipca, Toruń

in vigilia s. Jacobi apostoli

[Zofia Dulska, opatka toruńska i zgromadzenie cysterek-benedyktynek odstępują kanonikom chełmżyńskim na dwadzieścia lat w zamian za czynsz swój plac do składu drzewa w Młyńcu nad Drwęcą.]

Język łaciński.

A. Jak., sygn. tymez. ZC-B/ 14; Kopiariusz nr 4.

Uwagi: Znany jedynie z kop. nr 4, fol. 160-161. Druk: Reg.UBC, II, nr 1128; C. P. Woelky, Regesten, nr 128; s. 611; KBT, s. 57.

\section{5}

1609, 24 lipca, Chełmża

in vigilia s. Jacobi apostoli

[Kapituła chełmińska przyjmuje od toruńskich cysterek-benedyktynek plac nad Drwęca w Młyńcu w celu skałdowania na nim drewna na dwadzieścia lat w zamian za czynsz.]

\section{A. Jak. sygn. tymcz. ZC-B/ 14; Kopiariusz nr 4.}

Uwagi: Znany jedynie z kop. nr 4, fol. 161-162. Druk: Reg. C.P. Woelky, Regesten, nr 129, s.611; KBT, s. 57. 


\section{6}

1609, 18 listopada, Chełmża

feria 2 in vigilia s. Elizabeth

[Benedykt Woroncjusz, kapelan toruńskich cysterek-benedyktynek, wnosi do akt sądu miejskiego oświadczenie rezygnacji Jana Konopackiego, syna Macieja Konopackiego z Warszawy z dóbr Dźwierzno, Gziki i części dóbr Ocień na swojego brata Gabricla Konopackiego.]

\section{A. Jak., sygn. tymcz. ZC-B/ 14; Kopiariusz nr 4.}

Uwagi: Znany jedynie z kop. nr 4, fol. 208. Druk: Reg.C. P. Woelky, Regesten, nr 131, s. 612.

\section{7}

1610, 13 lutego, Golub

Sabbatho post Dominicam Sexagesima

[Paweł Orłowski, podsędek dobrzyński, zeznaje przed sądem w Golubiu sprzedaż winnicy położonej w Trzeposzu, przy młynie wraz ze wszystkimi budynkami wojewodzie malborskiemu, Jerzemu Kostce, za 800 pol. floren.]

\section{A. Jak., sygn. tymcz. ZC-B/ 14; Kopiariusz nr 4.}

Uwagi: Znany jedynie z kop. nr 4, fol. 275-276. Druk: Reg. C. P. Woelky, Regesten, nr 132, s. 612 .

\section{8}

1610, 25 lutego, Lubawa

[Wawrzyniec Gembicki, biskup chełmiński, potwierdza klasztorowi toruńskich cysterek-benedyktynek fakt udzielenia przez to zgromadzenie pożyczki w wysokości 10.000 pol. guld.w zamian za roczny czynsz Piotrowi Działyńskiemu.] Język łaciński.

\section{A. Jak., sygn. tymcz. ZC-B/ 14; Kopiariusz nr 4.}

Uwagi: Znany jedynie z kop. nr 4, fol. 158. Druk: UBC, II, nr 1129; Reg. C. P. Woelky, Regesten, nr 133, s. 612 .

\section{9}

1610, 3 czerwca, Przasnysz

feria 5 ante Trinitatis

[Mikołaj Krasiński, podkomorzy z Przasnysza i Makowa, którego córka Elżbieta Krasińska jest zakonnicą w toruńskim klasztorze cysterek-benedyktynek, zobowiązuje się do wypłacania jej przez pięć lat 60 pol. guld. z kwoty 800 pol. guld. rocznego czynszu, a następnie tej samej sumy klasztorowi.] 
A. Jak., sygn. tymcz. ZC-B/ 14; Kopiariusz nr 4.

Uwagi: Znany jedynie z kop. nr 4, fol. 164-165. Druk: Reg. C. P. Woelky, Regesten, nr 134, s. 612 .

1611, 15 lipca, Nowa Nieszawa

feria 2 ante festum s. Margarethae

[Stanisław Skarbasz ze swoją żoną Anną Śmiałkowną zapisali konwentowi toruńskich eysterek-benedyktynek 100 pol. guld. kapitału za czynsz w wysokości 6 pol. guld. zastawiając przy tym swój ogród w Nowej Nieszawie.]

A. Jak., sygn. tymcz. ZC-B/ 14; Kopiariusz nr 4.

Uwagi: Znany z kop. nr 4, fol. 172-173. Druk: Reg. C. P. Woelky, Regesten, nr 135, s. 613.

\section{1}

1612, 27 lutego, Lubawa

[Maciej Konopacki, biskup chełmiński, nadaje Zofii Dulskiej, ksieni toruńskich cysterek-benedyktynek, przywilej opuszczania klasztoru w celu inspekcji dóbr klasztornych w towarzystwie dwóch mniszek lub innych szlachetnych kobiet.]

\section{A. Jak., sygn. tymcz. ZC-B/ 17; Kopiariusz nr 2.}

Uwagi: Znany jedynie z kop. mr 2, fol. 60. Druk: Reg. C. P. Woelky, Regesten, nr 136, s. 613. Przywilej ten Maciej Konopacki obiecał już w roku 1611, w liście do panny ksieni, KBT, s. 60.

\section{2}

1612, 27 lutego, Lubawa

[Maciej Konopacki, biskup chełmiński, nakazuje aby Zofia Dulska, ksieni toruńskich cysterek-benedyktynek, kwaterowała prowizora, rzemicślników budowlanych pracujących w klasztorze i krewne odwiedzające zakonnice w osobnym budynku, takim jak dla kandydatek na mniszki.]

\section{A. Jak., sygn. tymcz. ZC-B/ 17; Kopiariusz nr 2.}

Uwagi: Znany jedynie z kop. nr 2, fol. 60-61. Druk: Reg. C. P. Woelky, Regesten, nr 137, s. 613.

\section{3}

1612, 27 lutego, Lubawa

[Maciej Konopacki, biskup chełmiński, pozwala Zofi Dulskiej, ksieni toruńskich cysterek-benedyktynck, uprosić na spowiednika dla swojego konwentu kapłana jezuite, u rektora toruńskich jezuitów; potwierdza też dwa wcześniejsze zezwolenia.] 
A. Jak., sygn. tymcz. ZC-B/ 17; Kopiariusz nr 2.

Uwagi: Znany jedynic z kop. nr 2, fol. 61. Druk: Reg.UBC,II, nr 1132; C. P. Woelky, Regesten, nr 138 , s. 613 .

\section{4}

1612, 8 marca, Chełmża

feria 5 post $S$. Gregorii

[Bartlomiej i Jan Dąbrowscy, synowie zmarłego Jana Dąbrowskiego, przenoszą przejęty po ojcu roczny czynsz w wysokości 24 pol. guld. płacony kapitule chełmińskicj ze swojego majątku rodowego na dobra Gierkowo i Sapoty.]

\section{A. Jak., sygn. tymcz. ZC-B/ 14; Kopiariusz ur 4.}

Uwagi: Znany jedynie z kop. nr 2, fol. 192-193. Druk: Reg. C. P. Woelky, Regesten, nr 139, s. 613 .

\section{5}

1612, 5 czerwca, Starogród

[Maciej Konopacki, biskup chełmiński, dopuszcza Benedykta Wroneckiego, Walentyna Plaze i Macieja Woikowskiego, kapelanów konwentu toruńskich cysterek-benedyktynek, do spowiadania w kościele klasztornym (w wypadku braku spowiednika zakonnego) i wygłaszania kazań.]

\section{A. Jak., sygn. tymcz. ZC-B/ 17; Kopiariusz nr 2.}

Uwagi: Znany z kop. nr 2, fol. 59. Druk: Reg. C. P. Woelky, Regesten, nr 140, s. 613.

\section{6}

\section{2, 18 czerwca, Chelmża}

[Maciej Konopacki, biskup chełmiński, upoważnia Zofię Dulską, opatkę toruńskich cysterek-benedyktynek, aby ta uroczyście przez stosownego kapelana przyjęła do budynku klasztornego swoje nowicjuszki, po odbyciu przez nie nowicjatu.]

\section{A. Jak., sygn. tymcz. ZC-B/ 17; Kopiariusz nr 2.}

Uwagi: Znany jedynie z kop nr 2, fol. 62. Druk: Reg. UBC, II, nr 132; C. P. Woelky, Regesten, nr 141, s. 614.

\section{7}

1612, 16 lipca, Chełmno

[Jerzy Konopacki, syn zmarłego Rafała Konopackiego, odstępuje bratu swego 
ojca, Maciejowi Konopackiemu, biskupowi chełmińskiemu, wieś Dźwierzno i część lasu w Ocieniu, część jako podarunek, część za 25.000 pol. guld.]

A. Jak., sygn. tymcz. ZC-B/ 14; Kopiariusz ur 4.

Uwagi: Znany jedynie z kop. nr 4, fol. 270-27l. Druk: Reg. UBC, II, nr 1133; C. P. Woelky, Regesten, nr 142, s. 614 .

\section{8}

1612, 6 sierpnia, Toruń

[Klasztor toruńskich cysterek-benedyktynek zawiera kontrakt w sprawie majątku Kamionki Wielkie, załączając inwentarz tych dóbr.]

\section{A. Jak., sygn. tymcz. ZC-B/ 14; Kopiariusz nr 4.}

Uwagi: Znany jedynie z kop. nr 4, fol. 182-185. Druk: Reg. C. P. Woelky, Regesten, nr 143, s. 614 .

\section{9}

1612, 22 października, Toruń

feria 2 post festum s. Hedwigis

[Jakub Gołocki, jako ojciec i opiekun ze swoją żoną Zofia Szampławską zeznają, że sprzedali w imieniu trzech małoletnich: Jakuba, Bartłomieja i Anny, Kamionki Wielkie Łukaszowi Szamplawskiemu wraz długiem 17.000 pol. guld.]

A. Jak., sygn. tymez. ZC-B/ 14; Kopiariusz nr 4.

Uwagi: Znany z odpisu w kop. nr 4, fol. 185. Druk: Reg. C. P. Woelky, Regesrten, nr 144, s. 614.

150

1612, 22 października, Toruń

feria 2 post festum s. Hedwigis

[Jakub Gołcki, sprzedaje dobra Kamionki Wielkie za 20.000 pol. guld. klasztorowi toruńskich cysterek-benedyktynek i kwituje odbiór powyższej kwoty.]

A. Jak., sygn. tymez. ZC-B/ 14; Kopiariusz nr 4.

Uwagi: Znany jedynie z kop. nr 4, fol. 186-189. Druk: Reg. C. P. Woelky, Regesten, nr 145, s. 614; KBT, s. 61 .

\section{1}

1613, 21 lutego, Lubawa

[Maciej Konopcaki, biskup chełmiński, zobowiązuje kanonika Odineta Perrenot, proboszcza z Niwy Sebastiana Grzybowskiego i kapelana katedralnego Filipa 
Zieleńskicgo, do rozwiązania nicporozumień toruńskich cysterek-benedyktynek i chełmińskich mniszek związanych z pożyczką.]

\section{A. Jak., sygn. tymez. ZC-B/ 17; Kopiariusz nr 2.}

Uwagi: Znany jedynie $z$ kop. nr 2, fol. 63. Druk: Reg.UBC, II, nr 1134; C. P. Woelky, Regesten, Inr 146 , s. 614 .

\section{2}

1613, 18 czerwea, Toruń

[Jan Osieczkowski, syn zmarłego Macieja Osieczkowskiego i Febronii Szczepańskiej (po drugim mężu Szampławskiej), odstępuje sumę zapisaną na Kamionkach Wielkich w wysokości 6.000 pol. guld. toruńskim cysterkom-benedyktynkom.]

\section{A. Jak. sygn. tymcz. ZC-B/ 14; Kopiariusz nr 4.}

Uwagi: Znany jedynie z kop. nr 4, fol. 190. Druk: Reg. C. P. Woelk y, Regesten, nr 148, s. 615.

\section{3}

1613, 21 paździcrnika, Toruń

feria 2 post s. Hedwigis

[Jakub Gołocki kwituje przyjęcie całej sumy za Kamionki Wielkie otrzymanej od Zofii Dulskiej, opatki toruńskiej wspólnoty cysterek-benedyktynek.]

\section{A. Jak., sygn. tymcz. ZC-B/ 14; Kopiariusz nr 4.}

Uwagi: Znany jedynie z kop. nr 4, fol. 191. Druk: Reg. C. P. Woelky, Regesten, nr 149, s. 615.

\section{4}

1614, 8 listopada, Lubawa

[Jan Kuczborski, biskup chełmiński, zezwala na przyszłość Zofii Dulskiej, opatce toruńskich cysterek-benedyktynek opuszczać klasztor z powodu wizytacji dóbr i uczestniczenia w rozprawach sądowych.]

\section{A. Jak., sygn. tymcz. ZC-B/ 17; Kopiariusz nr 2.}

Uwagi: Znany jedynie z kop. nr 2, fol. 64. Druk: Reg.UBC, II, nr 1135; C. P. Woelky, Regesten, nr 150 , s. 615 .

\section{5}

1614, 8 listopada, Lubawa

[Jan Kuczborski, biskup chełmiński, nakazuje na przyszłość Zofii Dulskicj, opatce toruńskich cysterek-benedyktynek, kwaterować prowizora klasztornego, pracujących w klasztorze rzemieślników budowlanych i odwiedzające zakonnice krewne, tak jak nowicjuszki, w osobnym budynku.] 
A. Jak., sygn. tymcz. ZC-B/ 17; Kopiariusz nr 2.

Uwagi: Znany z kop. nr 2, fol. 64-65. Druk: Reg. C. P. Woelky, Regesten, nr 15I, s. 615.

1614, 8 listopada, Lubawa

[Jan Kuczborski, biskup chełmiński, pozwala na przyszłość Zofii Dulskiej, opatce toruńskich cysterek-benedyktynek, upraszać sobie u rektora toruńskich jezuitów spowiednika dla swojego konwentu.]

A. Jak., sygn. tymcz. ZC-B/ 17; Kopiariusz nr 2.

Uwagi: Znany jedynie z kop. nr 2, fol. 65. Druk: Reg. C. P. Woelky, Regesten, nr 152, s. 615.

\section{7}

1614,8 listopada, Lubawa

[Jan Kuczborski, biskup chełmiński, upoważnia Zofię Dulską, opatkę toruńskich cysterek-benedyktynek, aby ta uroczyście przez stosownego kapelana przyjęla do budynku klasztornego swoje nowicjuszki, po odbyciu przez nie nowicjatu.]

A. Jak., sygn. tymez. ZC-B/ 17; Kopiariusz nr 2.

Uwagi: Znany z kop. nr 2, fol. 66. Druk: Reg. C. P. Woelky, Regesten, nr 153, s. 615.

158

1614, 27 listopada, Warszawa

Regnorum nostrorum Poloniae 27, Sueciae 21

[Zygmunt III, król polski, potwierdza torunskim cysterek-benedyktynek zakup Kamionek Wielkich.]

A. Jak., sygn. tymcz. ZC-B/ 14; Kopiariusz nr 4.

Uwagi: Znany z kop. nr 4, fol. 191-192. Druk: Reg. C. P. Woelky, Regesten, nr 154, s. 615.

\section{9}

1614, 1 czerwca, Radzyń

[Marcin Zrembrski skarży przed sądem Ludwika Mortęskiego, wojewodę chełmińskiego, w imieniu toruńskich cysterek-benedyktynek Jana Kretkowskiego z Brześcia, że ten dnia 26 maja 1614 r. najechał majątek klasztorny Kamionki Wielkie.]

A. Jak., sygn. tymcz. ZC-B/ 14; Kopiariusz nr 4.

Uwagi: Znany jedynie z kop. nr 4, fol. 198. Dnuk: Reg. C. P. Woelky, Regesten, nr 155, s. 616. 
1615, 27 lipca, Nowa Nieszawa

feria 2 post festum s. Jacobi

[Rozstaniec Skarbasz, mieszczanin nieszawski, wraz z żoną Zofią wystawiają klasztorowi toruńskich cysterek-benedyktynek skrypt dłużny na zaciagnictą w klasztorze pożyczkę w wysokości 100 pol. guld.]

A. Jak., sygn. tymcz. ZC-B/ 14; Kopiariusz nr 4.

Uwagi: Znany jedynie z kop. nr 4, fol. 174-175. Druk: Reg. C. P. Woclky, Regesten, nr 156, s. 616.

\section{1}

1615, 20 listopada, Sochaczew

feria 6 pridie festi Presentationis B. M. V.

[Agnieszka von Grabie, małżonka Adama Tomisławskiego, leguje ubogim i sierotom ze szpitala Św. Ducha w Toruniu 1000 pol. guld. zapisanych na jej wsi Przywieczerzino.]

A. Jak., sygn. tymcz. ZC-B/ 14; Kopiariusz nr 4.

Uwagi: Znany jedynje z kop. nr 4, fol. 201. Druk: Reg. C. P. Woelky, Regesten, nr 157, s. 616.

162

1616, 1 grudnia, Lubawa

[Jan Kuczborski, biskup chełmiński, nakazuje opatce toruńskich cysterek-benedyktynek, Zofii Dulskiej, aby swoje nowicjuszki, po odbyciu przez nie nowicjatu, uroczyście (poprzcz specjalnego kapelana) wprowadziła do budynku klasztornego.]

A. Jak., sygn. tymcz. ZC-B/ 17; Kopiariusz nr 2.

Uwagi: Znany jedynie z kop. nr 2, fol.66- 67. Druk: Reg. C. P. Woelky, Regesten, nr 158, s. 616.

\section{3}

1616, 1 grudnia, Lubawa

[Jan Kuczborski, biskup chełmiński, zezwala Zofii Dulskiej, opatce toruńskich cysterek-benedyktynek, na to, żeby mogła sobie wyprosić u rektora jezuitów spowiednika dla swojego konwentu.]

\section{A. Jak., sygn. tymcz. ZC-B/ 17; Kopiariusz nr 2.}

Uwagi: Znany jedynie z kop. nr 2, fol. 67. Druk: Reg. C. P. Woelky, Regesten, nr 159, s. 616. 


\section{4}

1617, 25 lutego, Warszawa

Regnorum nostrorum Poloniae 30, Suéciae 24

[Zygmunt III, król polski, odnawia na prośbę opatki toruńskich cysterek-benedyktynek, Zofii Dulskiej, zniszczony przez pożar oryginalny przywilej i transumpt dokumentu Wernera von Orselen, wiclkiego mistrza, z 1330 r., dotyczący pawa patronatu toruńskich zakonnic w Szynwałdzie.]

Oryg. Perg., rękopis, język łaciński, wym. 525x290+65 mm.

APT, Klasztor cysterek-benedyktynek, sygn. 14; A.Tor., nr 3045a; nr. 8.

Uwagi: Pieczęć wystawcy. Znany również z z kop. nr 4, fol, 22-23. Druk: Reg. C. P. Woelky, Regesten, nr 160 oraz 6 i 120; Kat. D. i L. Król., nr 323, s. 165-166.

165

1617,13 marca, Chełmża

feria 2 post festum s. Gregorii

[Gabriel Konopacki, syn Macieja, wojewody chełmińskiego, daje w zastaw, w obecności swojego brata Jana, dobra Dźwierzno i Gziki klasztorowi toruńskich cysterek-benedyktynek.]

A. Jak., sygn. tymcz. ZC-B/ 14; Kopiariusz nr 4.

Uwagi: Znany z kop. nr 4, fol. 211-212. Druk: Reg. C. P. Woelky, Regesten, nr 161, s. 617.

166

1617,22 kwietnia, Inowrocław

Sabbatho ante Dominicam Cantate

[Adam Golanczyk z Małych Kamionek wyjaśnia w imieniu Gabriela Konopackiego, że przekazanie toruńskim cysterkom-benedyktynkom dóbr Dźwierzno i Gziki wykonano 17 marca 1617 r.]

\section{A. Jak., sygn. tymcz. ZC-B/ 14; Kopiariusz nr 4.}

Uwagi: Znany z kop. nr 4, fol. 212-213. Druk: Reg. C. P. Woelky, Regesten, nr 162, s. 617; KBT, s. 64-65.

\section{7}

1617,22 kwietnia, Inowrocław

Sabbatho ante Dominicam Cantate

[Katarzyna Kostrzanka, wdowa po Janie Trzebuchowskim, rezygnuje jednocześnie w imieniu swoim i siostry Anny, opatki benedyktynek jarosławskich i Zofi, żony Stefana Batorego, z prawa do Folwarku Golubskiego na Wielkim Mokrem.]

A. Jak., sygn. tymez. ZC-B/ 14; Kopiariusz nr 4. 
Uwagi: Znany jedynie z kop. nr 4, fol. 252-256. Druk: Reg. C. P. Woclky, Regesten, nr 164, s. 617; KBT, s. 64-65.

\section{8}

1617,9 czerwca, Toruń

[Paweł Łążyński, opiekun Łukasza i Szymona Łążyńskich, dzieci jego brata Szymona, wraz z małżonką Anną Piwnicką, kwitują Zofii Dulskiej, opatce toruńskich cysterek-benedyktynek, przyjęcie 5000 flor. pol. zdeponowanych w klasztorze.]

A. Jak., sygn. tymcz. ZC-B/ 14; Kopiariuš nr 4.

Uwagi: Znany z kop. nr 4, fol.267-268. Druk: Reg. C. P. Woelky, Regesten, nr 165, s. 617.

169

1617,25 sierpnia, Toruń

[Konwent toruńskich cysterek-benedyktynek zawiera kontrakt na majątki Gzkiki i Dźwierzno z Konopackimi (Janem i Gabrielem).]

\section{A. Jak., sygn. tymcz. ZC-B/ 14; Kopiariusz nr 4.}

Uwagi: Znany jedynie z kop. nr 4, fol. 213-2I6. Druk: Reg. C. P. Woelky, Regesten, nr 166, s. 617; KBT, s. 67.

\section{0}

1617,26 sierpnia, Toruń

[Jan i Jakub Konopaccy, dziedzice zmarłego Gabriela Konopackiego, potwierdzają sprzedaż (w związku z zastawem) Dźwierzna i Gzik cysterkom-benedyktynkom toruńskim.]

\section{A. Jak., sygn. tymez. ZC-B/ 14; Kopiariusz nr 4.}

Uwagi: Znany z kop. nr 4, fol. 218-224. Druk: Reg.C. P. Woelky,Regesten, nr 167, s. 617.

\section{1}

1617, 26 sierpnia, Toruń

[Jakub Konopacki, syn Macieja, spadkobierca Gabriela Konopackiego uznaje dług zaciagnięty w klasztorze toruńskich cysterek-benedyktynek w wysokości 2000 flor. pol.]

\section{A. Jak., sygn. tymcz. ZC-B/ 14; Kopiariusz nr 4.}

Uwagi: Znany jedynie z kop. nr 4, fol 225-226. Druk: Reg. C. P. Woelky, Regesten, nr 168, s. 618 . 


\section{2}

1617, 10 października, Toruń

[Jan Kuczborski, biskup chełmiński, zatwierdza ugodę zawartą pomiędzy cysterkami-benedyktynakmi toruńskimi i Radą miasta Torunia dotyczącą różnych spraw spornych.]

Oryg. Perg., do konserwacji, rękopis, język łaciński, wym. $615 x 453+12 \mathrm{~mm}$.

ADPel., Diploma et epistolae, KI. Ben. (Toruń) 18; tamże nr 10; A. Jak., nr 28.

Uwagi: Druk: UBC, II, nr 1136; Reg. C. P. Woelky, Regesten, nr 169, s. 618.

\section{3}

1617,16 października, Toruń

feria 2 post festum s. Hedwigis

[Chełmiński sąd ziemski zgadza się na sprzedaż dóbr Dźwierzno i Gziki cysterkom-benedyktynkom toruńskim.]

\section{A. Jak., sygn. tymcz. ZC-B/ 14; Kopiariusz nr 4.}

Uwagi: Znany z kop. nr 4, fol. 227. Druk: Reg. C. P. Woelky, Regesten, nr 170, s. 618.

\section{4}

1617,16 października, Toruń

feria 2 post festum s. Hedwigis

[Adam Gołanczyn z Kamionek wyjaśnia w imieniu Jana Konopackiego, dziedzica wojewody Gabiela Konopackiego, że toruńskie cysterki-benedyktynki posiadają już Dźwierzno i Gziki.]

A. Jak., sygn. tymcz. ZC-B/ 14; Kopiariusz nr 4.

Uwagi: Znany jedynie z kop, nr 4, fol, 221-225. Druk: Reg. C. P. Woelky, Regesten, nr 171, s. 618 .

1617, 3 listopada, Toruń

[Jan Konopacki, opiekun swoich nieletnich braci, przywołuje ponownie kontrakt sprzedaży Dźwierzna i Gzik z 1617 r. i każe przyjąć nowy, w którym tourńskie cysterki-benedyktynki otrzymują połowę dóbr jako darowiznę, a za zakup drugiej płaca 30.000 pol. guld.]

\section{A. Jak., sygn. tymcz. ZC-B/ 14; Kopiariusz nr 4.}

Uwagi: Znany jedynie z kop. nr 4, fol. 228-233. Druk: Reg. C. P. Woelky, Regesten, nr 172, s. 618 . 


\section{6}

1617, 23 listopada, Radzicjowo

feria 5 ante festum s. Catherinae

[Katarzyna Kostrzanaka, siostra zmarłego wojewody pomorskiego Krzysztofa Kostki, wdowa po Janie Trzebuchowskim i siostra wojewody malborskiego Jerzego Kostki, darowywuje w imieniu swoim i braci toruńskim cysterkom-benedyktynkom Winnicę koło Tounia.]

A. Jak., sygn. tymez. ZC-B/ 14; Kopiariusz nr 4.

Uwagi: Znany jedynie z kop. nr 4, fol. 276-278. Druk: Reg. C. P. Woelky, Regesten, m 173, s. 618 .

\section{7}

1617,30 listopada, Warszawa

Regnorum nostrorum Poloniae 30, Sueciae 24

[Zygmunt III, król polski, odnawia klasztorowi toruńskich cysterek-benedyktynek ugodę zawartą w sprawie zakupu przez zakonnice Dźwierzna i Gzik.]

A. Jak, sygn. tymcz. ZC-B/ 14; Kopiariusz nr 4.

Uwagi: Znany jedynie z kop. nr 4, fol. 234. Druk: Reg. C. P. Woelky, Regesten, nr 174, s. 619.

178

1618,15 stycznia, Łężyca

feria 6 ante festum s. Priscae

[Jakub Kraśnicki, wojewoda inowrocławski, zobowiązuje się swoje siostry, które zostały toruńskimi zakonnicami, Mariannę i Urszulę wyposażyć w kwotę 3.000 flor.pol., od której wypłacany będzie roczny cznysz: 400 flor. pol.]

A. Jak., sygn. tymcz. ZC-B/ 14; Kopiariusz nr 4.

Uwagi: Znany jedynic z kop. nr 4, fol.293-294. Druk: Reg. C. P. Woelky, Regesten, nr 175, s. 619 .

1618, 5 lipca, Chełmża

[Jan Kuczborski, biskup chełmiński, pozwala Zofii Dulskiej, opatce toruńskich cysterek-benedyktynek pojechać do Radomia, w sprawie nowej fundacji.]

\section{A. Jak., sygn. tymcz. ZC-B/ 17; Kopiariusz nr 2.}

Uwagi: Znany jedynie z kop. nr 2, fol. 67-68. Druk: Reg. C. P. Woelk y, Regesten, nr 176, s. 619. 
1618, 29 sierpnia, Chełmża

feria 4 post festum s. Augustini

[Stanisław Pszonka potwierdza klasztorowi toruńskich cysterek-benedyktynek fakt zaciagnięcia przez niego pożyczki, w wysokości 60 flor. pol. za roczny czynsz: 3 flor. pol. obciążających jego dom w Dużych Rybakach w Toruniu.]

\section{A. Jak., sygn. tymcz. ZC-B/ 14; Kopiariusz nr 4.}

Uwagi: Znany jedynic z kop. nr 4, fol. 300-303. Druk: Reg. C. P. Woelky, Regesten, nr 177, s. 619 .

\section{1}

1618, 7 września, Chełmża

feria 6 in vigilia Nativitatis $B . M . V$.

[Katarzyna Kostrzanka, wdowa po Janie Trzebuchowskim, potwierdza swoje zrzeczenic się Winnicy koło Torunia na korzyść toruńskich cysterek-benedyktynek.]

\section{A. Jak., sygn. tymcz. ZC-B/ 14; Kopiariusz nr 4.}

Uwagi: Znany jedynie z kop. nr 4, fol. 279-281. Druk: Reg. C. P. Woelky, Regesten, nr 178, s. 619 .

1618, 7 września, Chełmża

feria 6 in vigilia Nativitatis $B . M . V$.

[Katarzyna Kostrzanka, wdowa po Janie Trzebuchowskim, potwierdza swoje zrzeczenie się Folwarku Golubskiego, na Mokrem w Toruniu, na korzyść klasztoru toruńskich cysterek-benedyktynek.]

\section{A. Jak., sygn. tymcz. ZC-B/ 14; Kopiariusz nr 4.}

Uwagi: Znany jedynie z kop. nr 4, fol. 259-260. Druk: Reg. C. P. Woelky, Regesten, nr 179, s. 619 .

\section{3}

\section{8, 24 września, Warszawa}

Regnorum nostrorum Poloniae 31, Sueciae 24

[Zygmunt III, król polski, potwierdza zakonnicom toruńskim nadanie im Folwarku Golubskiego i Winnicy koło Torunia przez Katarzynę Kostrzankę.]

\section{A. Jak., sygn. tymcz. ZC-B/ 14; Kopiariusz nr 4.}

Uwagi: Znany jedynie z kop. nr 4, fol. 261. Druk: Reg. C. P. Woelky, Regesten, nr 180, s. 619. 


\section{4}

1619, 18 listopada, Chełmża

feria 2 in vigilia Elisabeth

[Benedykt Woroncjusz, kapelan cysterek-benedyktynck toruńskich, każe różne dokumenty dotyczące sprzedaży dóbr Dźwierzno i Gziki wnieść do akt sądowych chełmżyńskich.]

\section{A. Jak., sygn. tymez. ZC-B/ 14; Kopiariusz nr 4.}

Uwagi: Znany jedynie z kop. nr 4, fol 237-242. Druk: Reg. C. P. Woelky, Regesten, nr 181, s. 619 .

\section{5}

1619, 3 listopada, Lubawa

[Jan Kuczborski, biskup chełmiński, napomina spowiednika toruńskich cysterekbencdyktynek, że ma traktować mniszki z całym rozsądkiem i ostrożnością.]

A. Jak., sygn. tymcz. ZC-B/ 17; Kopiariusz nr 2.

Uwagi: Znany jedynie z kop. nr 2, fol.69. Druk: Reg. C. P. Woelky, Regesten, nr 182, s. 620.

\section{6}

1619, 21 listopada, Chełnıza

[Kapituła chełmińska, transumuje na prośbę Benedykta Woroncjusza, kapelana toruńskich cysterek-benedyktynek, dokument Wernera von Orseln, wielkiego mistrza, z 1327 r., dotyczący przeniesienia zakonnic z ich siedziby przy szpitalu Św. Ducha do nowej, przy kościele Św. Krzyża.]

\section{A. Jak., sygn. tymcz. ZC-B/ 14; Kopiariusz nr 4.}

Uwagi: Znany jedynie z kop. nr 4, fol. 20. Druk: Reg. C. P. Woelky, Regesten, nr 183, s. 620.

\section{7}

1620, 11 lipca, Rzym

Pontificatus anno 16

[Paweł V papież, nadaje toruńskim cysterkom-benedyktynkom odpust, na siedem lat, na święto Wniebowzięcia Najświętszej Marii Panny.]

A. Jak., sygn, tymcz. ZC-B/ 17; Kopiariusz nr 2.

Uwagi: Znany jedynie z kop. nr 2, fol 41. Druk: Reg. C. P. Woelky, Regesten, nr 184, s. 620. 


\section{8}

1620, 21 czerwca, Toruń

[Cysterki-benedyktynki toruńskie zawierają intercyzę z panami Konopackimi.]

A. Jak., sygn. tymcz. ZC-B/ 14; Kopiariusz nr 4.

Uwagi: Znany jedynie z kop, nr 4, fol. 242-244. Druk: Reg. C. P. Woelky, Regesten, nr 185, s. 620 .

\section{9}

1621, 9 lipca, Toruń

[Cysterki-benedyktynki toruńskie wszczynają rozprawę przeciwko Konopackim dotyczącą Dźwierzna i Gzik.]

\section{A. Jak., sygn. tymez. ZC-B/ 14; Kopiariusz nr 4.}

Uwagi: Znany jedynic z kop. nr 4, fol. 214-247. Druk: Reg. C. P. Woelky, Regesten, nr 186, s. 620 .

1622, 26 września, Warszawa

\section{0}

[Zygmunt III, król polski, konfirmuje legat Zygmunta I, króla polski, dla Jakuba Rokucza z 1526 r. dotyczący Dźwierzna i innych majątków.]

Oryg. Perg., rękopis, język łaciński.

\section{A. Jak. nr 29; 18.}

Uwagi: Pieczęć wystawcy. Druk: UBC, II, nr 1139; Reg. C. P. Woclky, Regesten, nr 187, s. 620.

\section{1}

1627,8 października, Golub

[Michał Rafał Kostka, sprzedaje wraz ze swoją siostrą swoją część Folwarku GoJubskiego i Winnicy koło Torunia toruńskim cysterkom-benedyktynkom za 1.000 flor. pol.]

\section{A. Jak., sygn. tymez. ZC-B/ 14; Kopiariusz nr 4.}

Uwagi: Znany jedynie z kop. nr 4, fol. 262-263. Druk: Reg. C. P. Woelky, Regesten, nr 188, s. 620 .

1659, 29 marca, Toruń

[Adam Kos, biskup chełmiński, stwicrdza, że Rada Miasta Torunia musi oddać toruńskim benedyktynkom, po zburzeniu ich klasztoru przy szpitalu Św. Ducha, 
trzy kamienice na ulicy Żeglarskiej, lub inne wygodne dla nich pomieszczenia, bądź odbudować dawny klasztor.]

Uwagi: Znany jedynie z Druku: Thorn. Denk., p. 2; Reg. C. P. Woelky, Regesten, nr 192, s. 621; KBT, s. 84 .

\section{3}

1659, 3 kwietnia, Toruń

[Mikołaj Prazmowski, wielki kanclerz koronny, stwierdza w imieniu króla, że Rada Miasta Torunia musi oddać toruńskim benedyktynkom trzy kamienice na ulicy Żeglarskiej, lub inne wygodne dla nich pomieszczenia, bądź odbudować dawny klasztor.]

Uwagi: Znany jedynic z Druku: Thorn. Denk., p. 28; Reg. C. P. Woelky, Regesten, nr 193, s. 621.

\section{4}

1662, 9 lipca, Toruń

Freitag nach Frohnleichnam

[Sąd królewski, orzeka w sprawie sporu toruńskich benedyktynek z Radą Miasta Torunia, że kościół św. Jakuba wraz z prawem patronatu i wyposażenicm musi zostać zwrócony zakonnicom w ciągu 6-ciu tygodni.]

Uwagi: Znany jedynie z Druku: Thorn. Denk.,(4). fol.11-61; Reg. C. P. Woelky, Regesten, nr 194, s. 621 .

\section{5}

1662, 28 lipca, Warszawa

[Klasztor toruńskich benedyktynek zawiera z miastem Toruń kontrakt w sprawie zburzonego klasztoru Św. Ducha.]

A. Jak., sygn. tymez. ZC-B/ 14; Kopiariusz nr 4.

Uwagi: Znany jedynie z kop. nr 4, fol. 17. Druk: Reg. C. P. Woelky, Regesten, nr 195, s. 621.

\section{6}

1665,14 stycznia, Warszawa

feria 4 ante festum s. Prischae

[Jan Kazimierz, król polski, skazuje Radę Miasta Torunia oraz Gminę protestancką w Toruniu na wydanie toruńskim benedyktynkom kościoła św. Jakuba.]

Oryg. Perg., stan dobry, rękopis, język łaciński, 10 k., wym. 223x326 mm.

ADPel., Diploma et epistolae, Kl. Ben. (Toruń) 19; tamże nr 1; A. Jak., nr 30. 
Uwagi: Pieczęć wystawcy. Druk: UBC, II, nr 1184; Reg. C. P. Woelky, Regesten, nr 196, s. 62; Hartknoh, Kirchenges., p. 966, Beil. VIIl.

1667, 18 lipea, (brak miejsca)

[Miasto Toruń przekazuje toruńskim benedyktynkom ich dawny kościół parafialny pod wezwaniem św. Jakuba.]

Uwagi: Fakt zanany jedynie z Druku: Hartknoch, Kirchengesch, p. 975.

\section{8}

1676, 10 kwietnia, Kraków

Regni nostri 2 anno

[Jan III Sobieski, król polski, pozwala toruńskim benedyktynkom warzyć piwo na potrzeby swoje i swoich ludzi.]

Oryg. Perg., do konserwacji, rękopis, język laciński, wym. 268x540+85 mm.

A. Jak., nr 32; 9.

Uwagi: Pieczęć wystawcy. Druk: Reg. C. P. Woelky, Regesten, nr 198, s. 622.

\section{9}

1676,26 maja 1676

Pontificatus anno 7

[Klemens X, papież, nadaje odpust na dzień św. Jakuba dla panien benedyktynek, ważny na 10 lat.]

Oryg. Perg., do konserwacji, rękopis, język laciński, wym. 140x390 mm.

\section{A. Jak., Brak sygn.}

\section{0}

1700,15 czerwca, Toruń

[Rada Miasta Torunia zaciąga pożyczkę na trzy lata za czynsz u toruńskich benedyktynek w wysokości 10.000 guld. pol. wystawiając list dłużny.]

\section{A. Jak., sygn. tymez. ZC-B/ 14; Kopiariusz nr 4.}

Uwagi: Znany jedynie z kop. nr 4, fol. 107-108. Druk: Reg. C. P. Woelky, Regesten, nr 199, s. 622 . 
1701, 16 lipca, Warszawa

[August II Mocny, król polski, nadaje toruńskim benedyktynkom prawo warzenia piwa dla siebie $i$ swoich poddanych, wwożenia zboża do miasta oraz stawiania budynków na swoich gruntach.]

Oryg. Perg., do konserwacji, rękopis, język łaciński, wym. 451×327+31 mm.

ADPel., Diploma et epistolae, KI. Ben. (Toruń) 20; tamże nr 14; A. Jak., nr 33.

Uwagi: Pieczęć wystawcy. Druk: UBC,II, nr 1207; Reg. C. P. Woelky, Regesten, nr 200, s. 622.

202

1706, 8 stycznia, Rzym

Pontificatus anno 6

[Klemens XI, papież, nadaje odpust toruńskim benedyktynkom na święto św. Jakuba, ważny na 10 lat]

Oryg. Perg., do konserwacji, rękopis, język łaciński, wym. wym. 125x390 mm.

A. Jak. nr 34.

Uwagi: Druk: Reg.C. P. Woelky, Regesten, nr 201, s. 622.

203

1709,25 stycznia, Bydgoszcz

feria 6 ipso die Conversionis S. Pauli

[Jan Stanisław Chojnicki, wydaje toruńskim benedyktynkom 10.000 guld. pol. od magistratu toruńskiego.]

Oryg., rękopis, język niemiecki.

A. Jak., sygn. tymez. ZC-B/ 14; Kopiariusz nr 4.

Uwagi: Znany jedynie z kop. nr 4, fol. 7. Druk:Reg.C. P. Woelky, Regesten, nr 202, s. 622.

204

1715, 13 czerwca, Rzym

Pontificatus anno 15

[Klemens XI, papież, nadaje odpust na dzień św. Jakuba ołtarzowi św. Jakuba w kościele panien benedyktynek toruńskich pod wezwaniem św. Jakuba, ważny 10 lat.]

Język łaciński

A. Jak, nr 35.

Uwagi: Znany z Druk: Reg. C. P. Woelky, Regesten, nr 203, s. 622. 
1717, 29 lipca, Rzym

Pontificatus anno 17

[Klemens XI, papież, nadaje odpust w postne piątki w kościele św. Jakuba, ważny na 10 lat.]

Oryg. Perg., do konserwacji, rękopis, język laciński, wym. 123x450 mm.

A. Jak, nr 36.

Uwagi: Druk: Reg. C. P. Woelky, Regesten, nr 204, s. 622.

\section{6}

1721, 5 listopada, Toruń

[Miasto Toruń zawiera z klasztorem toruńskich benedyktynek transakcję względem zaległych odsetek od pożyczonej miastu sumy 10.000 pol. guld.]

A. Jak., sygn. tymez. ZC-B/ 14; Kopiariusz nr 4.

Uwagi: Znany jedynie z kop. nr 4, fol. 102. Druk: Reg. C. P. Woel ky, Regesten, nr 205, s. 622.

\section{7}

1723, 29 listopada, Rzym

Pontificatus anno 3

[Innocenty XIII, papież, nadaje odpust zupełny, dawany w obliczu śmierci, dla wszystkich zatrzymujących się w klasztorze benedyktynek toruńskich osób, bez okresu ważności.]

Oryg. Perg., do konserwacji, rękopis, język laciński, wym. 124x424 mm.

A. Jak, nr 37.

Uwagi: Pieczęc wystawcy. Druk; Reg. C. P. Woelky, Regesten, nr 206, s. 623.

1724,14 grudnia, Toruń

\section{8}

[Sąd królewski, przeprowadza dochodzenie i rozsądza spór graniczny pomiędzy klasztorem toruńskich benedyktynek a miastem Toruń dotyczący terenu po szpitalu Sw. Ducha oraz Folwarku Golubskiego.]

A. Jak., sygn. tymcz. ZC-B/ 14; Kopiariusz nr 4.

Uwagi: Znany jedynie z kop. nr 4, fol. 79-81. Druk: Reg. C. P. Woelky, Regesten, nr 207, s. 623.

1732, 25 stycznia, Rzym

Pontificatus anno 2 
[Klemens XII, papież, nadaje toruńskim benedyktynkom odpust na święto św. Jakuba w kościele klasztornym i parafialnym pod wezwaniem św. Jakuba, na 10 lat.]

Oryg. Perg., słan dobry, rękopis, jçzyk łaciński, wym. 142×384 mm.

A. Jak, nr 39.

Uwagi: Druk. Reg. C. P. Woelky, Regesten, nr 209, s. 623.

\section{0}

1732, 22 kwietnia, Rzym

Pontificatus anno 2

[Klcmens XII, papież, nadaje odpust taki jak w Rzymie w Bazylice św. Piotra, dla tych, którzy 12 razy w roku nawiedzą 7 ołtarzy w kościele św. Jakuba.]

Oryg. Perg., stan dobry, rękopis, język łaciński, wym. $143 \times 390 \mathrm{~mm}$.

A. Jak, $\mathbf{n r} 40$.

Uwagi: Druk: Rcg. C. P. Woelky, Regesten, nr 210, s. 623.

\section{1}

1732, 22 kwietnia, Rzym

Pontificatus anno 2

[Klemens XII, papież, nadaje odpust na postne piątki w kaplicy klasztornej sióstr benedyktynek w Toruniu, na 10 lat.]

Oryg. Perg., stan dobry, rękopis, język łaciński, wym. 397x150 mm.

A. Jak, nr 41.

Uwagi: Druk: Reg. C. P. Woelky, Regesten, nr 211, s. 632.

\section{2}

1732, 22 kwietnia, Rzym

Pontificatus anno 2

[Klemens XII, papież, nadaje odpust zupełny, dawany w obliczu śmierci, dla wszystkich zatrzymujących się w klasztorze benedyktynek osób, ważny na 10 lat.]

Oryg. Perg., stan dobry, rękopis, język łaciński, wym. 390x142 mm.

\section{A. Jak, nr 42.}

Uwagi: Druk: C. P. Woclky, Regesten, nr 212, s. 623. 


\section{3}

1761, 13 lipca, Rzym

Pontificatus anno 3

[Klemens XII, papież, nadaje odpust toruńskim benedyktynkom na dzień św. Rocha lub następny, odprawiany w kaplicy św. Rocha w Brzezinku.]

Oryg. Pcrg., stan dobry, rękopis, język łaciński, wym. 420x158 mm.
A. Jak., nr 43.

\section{4}

1761, 27 lipca, Rzym

Pontificatus anno 2

[Klemens XII, papież, nadaje toruńskim benedyktynkom odpust na dwa dni ustalone przez ordynariusza za 20 godzin modłów w klasztornej kaplicy.]

Oryg. Perg., stan dobry, rękopis, język łaciński, wym. 409x169 mm.

\section{A. Jak, nr 44.}

Uwagi: Druk: C. P. Woelky, Regesten, nr 213, s. 623.

\section{5}

1772, 7 marca, Rzym

Pontificatus anno 3

[Klemens XIV, papież, nadaje toruńskim benedyktynkom odpust na przypadający w mszale rzymskim dzień św. Jakuba, ważny na 10 lat.]

Oryg. Perg., stan dobry, rękopis, język laciński, wym. $422 \times 189$ mm.

\section{A. Jak, $\mathrm{nr} 45$.}

Uwagi: Druk: Reg. C. P. Woelky, Regesten, nr 214, s. 623.

\section{6}

1782, 16 maja, Rzym

Pontificatus anno 8

[Pius VI, papież, nadaje toruńskim benedyktynkom odpust na dzień św. Jakuba Apostoła oraz zezwolenie na odprawianie 40 godzin nabożeństwa w kościele św. Jakuba w Toruniu, ważny na 10 lat.]

Oryg. Perg., stan dobry, rękopis, język laciński, wym. 418x139 mm.

\section{A. Jak, nr 46.}

Uwagi: Na odwrocie dokumentu zezwolenie biskupa Józefa Rudnickiego na odbudowę dachu w kościele w Chełmnie. Druk: Reg. C. P. Woelky, Regesten, nr 215, s. 623. 


\section{Akta ogólne. Organizacja. Życie codzienne i duchowe}

\section{7}

[Konstytucje cysterskie uzupełniające Regułę św. Benedykta z Nursji.] [1311-1609]

Uwagi: Nieistniejące. Odnalezione w klasztorze toruńskim przez Zofię Dulską, ksienię. Ich istnienie poświadcza zapis w Kronice benedyktynek chelmińskich (KBCH, s. 100).

\section{8}

Annales, to jest Roczne dzieje klasztoru panien benedyktynek w Toruniu.

\section{$1311-1666$}

Księga, papicr, oprawa skórzana, jasny brąz, do konserwacji, rękopis, j̧̨zyk polski, 356k., folio.

ADPelp. MonasticaXIII, Benedyktynki-Toruń, nr 1; 46; 5.

Uwagi: Druk: W. Szoldrski, Kronika benedyktynek toruńskich (KBT), Mies. Diec. Chełm., 6(1934) nr 2, s. 136-152; nr 3, s. 247-262; nr 4, s. 377-390, nr 5-6, s. 498-520; nr 7-8, s. 595-610.

\section{9}

[Kopiariusz przywilejów i czynszów.]

[1311-1758]

Księga, papicr, oprawa perg., ziclona, stan dobry, rękopis, jধ̨zyk nicmiccki, polski, folio.

A. Jak., nr 47; sygn.tymex.ZC-B/15.

Uwagi: Druk fragmentu kop.: W. Szołdrski, Z dziejów benedyktynek toruniskich, Mies. Diec. Chelm., 2(1930), s. 757-776. ZD: Pł. nr 10.

\section{0}

[Kopiariusz spraw i dokumentów klasztornych.]

[1327-1664]

Księga, papier, oprawa perg., czerwony, do konserwacji, rękopis, język polski, laciński, 342k., folio.

\section{A. Jak., nr 4; 49; sygn.tymez.ZC-B/14.}

Uwagi: ZD:Pł. nr 61 i 62 . Liczne spacje: s. 11-16; 26-34; 37-39; 42-48; 59-62; 67-70; 82-86; 82-86; $103 ; 108 ; 120-121 ; 123 ; 129 ; 132-145 ; 164-171 ; 176-181 ; 195-197 ; 199-200 ; 203-208 ; 244 ; 266$; $283-292 ; 312-342$. 


\section{1}

[Kopiariusz przywilejów odpustowych i nadań osób duchownych, konfraternii. Księga przywilejów.]

[1336-1612]

Księga, papier, oprawa perg., żółty; stan dobry, rękopis, język łaciński, 166 k., folio.

A. Jak., nr 2; 48; sygn. tymez. ZC-B/17.

Uwagi: ZD: Pł. nr 23.

\section{2}

Życie klasztorne.

[1579-1825]

Teczka, papier, stan dobry, rękopis, język łaciński, polski, $240 \mathrm{~s}$.

\section{A. Jak., Teka nr 1; sygn. tymcz. ZC-B/1.}

Uwagi: Liczne pieczęcie konwentu toruńskicgo i biskupów chelmińskich. Fascykuły: kandydatki do klasztoru; obrona reguły w Rzymie; rcforma reguly chełmińskiej; spowiednik klasztorny; odpusty; klauzura; wybór ksieni; tułaczka w czasie zarazy. ZD:Pł.nr 6 i 39.

\section{3}

Śluby zakonne.

[1579-1825]

Akta luźne, papier, stan dobry, rękopis.
A. Jak., sygn. tymez. ZC-B/2.

Uwagi: Nie wiadomo, z której teki pochodza.

[Księgi pamiętne rzeczy albo spraw klasztoru Pawiańskiego (sic!) u Św. Ducha w Toruniu.]

[1598-1748]

Księga, papier. oprawa skóra, bardzo zniszczona, do konserwacji, rękopis, język laciński, polski, $458 \mathrm{s.}$, kwadrant.

\section{A. Jak., nr 54; sygn. tymcz. ZC-B/12.}

Uwagi: Spacje: $13-28,36,61-64,67-122,135-298,300-342,349-358,395-456$. Wiadomości o posagach i granicach dóbr. ZD:Pł. nr 46. 
[1620-1821]

Teczka, papier, stan dobry, rękopis, język łaciński, polski, $72 \mathrm{~s}$.

A. Jak., Teka nr 27, sygn. tymcz. ZC-B/4.

Uwagi: Fascykuly: udział biskupa w proccsach klasıtornych; dekrety wizytacyjnc; przywilcje biskupa dla klasztoru. ZD: Pł. nr 7.

\section{6}

Reguła św. ojca Benedykta z dawna władzą Stolice Apostolskiej potwierdzona, a teraz na język polski z konstytucjami albo ustawami tegoż bł. Patriarchy dla panien zakonnych zgromadzenia kassyneńskiego wiernie przetłumaczona. $1626-1626$

\section{A. Ben. Lomża, bez sygn.}

Uwagi: Unikatowa. Toruń 1626. Pozycja odtworzona na zasadzie analogii. Cary nakład eniszczono w 1634 r. Wspomina o niej s. Borkowska w swoich pracach: Panny siostry, s. 357; Życie codzienne, s. 343.

\section{7}

Reguła św. ojca Benedykta, z łacinskiego przetłumaczona, i z rcformacja porządków chełmińskiego, toruńskiego, żarnowieckiego, nieświeskiego i inszych wszystkich (...) które teraz są i na potem zjednoczone będą, klasztorów panieńskich.

\section{5-1635}

Ksiçga, druk, język polski.

Uwagi: Wyd. II. Lublin 1635. Zob. M. Borkowska, Panny siostry, s. 357.

\section{8}

Status Monasterii Sanctimonialium Torunensis Regula S. Benedicti 1789. [1671-1814]

Poszyt, papier, mocno zabrudzony, do konserwacji, rękopis, język łaciński, polski, $340 \mathrm{~s}$.

\section{A. Jak., V.VIII.; sygn. tymez. ZC-B/43.}

Uwagi: Spis książek biblioteki konwenckiej; wykazy zakonnic; akata personalne; egzaminy; pieczęcie Wojciecha Picchowskiego; Kurii biskupiej; Min. Spr. Wew. Ks. Warszawskiego; nowa pieczçć toruńskich zakonnic: s. 216, 230, 258. ZD:Pł. nr 51-52.

Rząd pruski-kasata klasztoru.

[1772-1818] 
Teczka, papier, stan dobry, rękopis/druk, język poiski, łaciński, ok. $172 \mathrm{~s}$.

ADPel., MonasticaXIII, Benedyktynki-Toruń, nr 33.

Uwagi: Akta kasacyjne; pensja benedyktynek; wolność od akcyzy; transakcje finansowe; regulacja kapitałów; drzewo na opał, hołdowanie królowi pruskiemu. ZD:Pł nr 100.

Kloster. Acta. Gen. Des Liquidations Wesen desselben, wegen des Forderungen an den Staat und dem was dem anghängig beteffend.

[1797-1829]

Poszyt, papier, đo konserwacji, rękopis/druk, język łaciński, niemiecki, $130 \mathrm{~s}$.

A. Jak., Nro. 20.IV; a.b.; sygn. tymez. ZC-B/ 53.

\section{1}

I. Acta des Benedictiner Nonnen Klosters zu Thorn die Einrechung der Uebersicht des Personal Bestandes des Klosters an das Ober Presidium von West Preussen, und was dem anhängig betreffend. II. Verfassung des Klosters.

[1816-1831]

Poszyt, papier, do konserwacji, rękopis, język łaciński, niemiecki, $73 \mathrm{~s}$.

A. Jak., Nro. I.IV; sygn. tymcz. ZC-B/79.

Uwagi: Skład osobowy i liczebnośc konwentu.

\section{2}

Kloster. Acta betreffend des Benedictiner Nonnenklosters zu Thorn- Neustadt. [1822-1833]

Poszyt, papier, do konserwacji, rękopis, język niemiccki, polski, $103 \mathrm{~s}$.

A. Jak., P.78; Kl. A.B; sygn. tymez. ZC-B/81.

\section{3}

Kloster. Acta des Benedictiner Nonnen Klosters zu Thorn die Auffasung der Nonnen Kloster zu Thorn und ihren Uebersiedlung nach Zarnowitz betreffend. [1793-1833]

Poszyt, papier, do konserwacji, rękopis, jॄ̨zyk niemiecki, polski, $298 \mathrm{~s}$.

A. Jak., Kb. Vol. V.; Nro. 48; sygn. tymez. ZC-B/ 87.

Uwagi: Pieczęć nowa zakonnic toruńskich: s. 99. ZD:Pł. nr 53. 


\section{Rozporządzenia wladz duchownych i świeckich. Dekrety i korespondencja}

\section{4}

Klasztor. Korespondencja klasztoru różna z rządem pruskim i magistratem toruńskim od 1790-1805 r. I.Rescripta z różnych subselliów od 1790 r. aż do 1801 r.. II. Rezolucje z subseliów pruskich w różnych interesach klasztoru z lat 1794-1805. [1790-1805]

Poszyt, papier, do konserwacji, rękopis/druk, język niemiecki, polski, $367 \mathrm{~s}$

A. Jak., K.b., Vol. XI; sygn. tymcz. ZC-B/47.

Uwagi: Liczne pieczęcie władz pruskich państwowych i micjskich.

\section{5}

Kloster. Korespondencja ze Rządem Pruskim, Magistratem Tor[uńskim] etc. od 1804-1824.

[1804-1824]

Poszyt, papier; do konserwacji, rękopis/druk, język niemiecki, polski, $575 \mathrm{~s}$.

A. Jak., K.b. Vol. XII.; sygn. tymez. ZC-B/65.

Uwagi: Pieczęć: Kongl. Regierung zu Marienwerder.

\section{6}

[Korespondencja klasztou z władzami w różnych sprawach i rozporządzenia oraz ich kopie.]

[1805-1842]

Poszyt, papier, bez oprawy lub okładki, do konserwacji, rękopis/druk, język niemiecki, $213 \mathrm{~s}$.

A. Jak., sygn.tymcz. ZC-B/68.

\section{7}

[Korespondencja z władzami pruskimi w sprawach majątkowych i kompetencji.] [1806-1825]

Poszyt, papier, do konserwacji, rękopis/druk, język łaciński, polski, $256 \mathrm{~s}$.

A. Jak., Nro. 18.IV.; sygn. tymez. ZC-B/70.

Uwagi: Pieczęcie administracji diecezjalnej i rządowej także Księstwa Warszawskiego; pieczęć sygnetowa opłatkowa Anny Białobockiej, ksieni toruńskiej z 1810 r., s. 147. 


\section{8}

Rezolucje w interesach klasztornych zarządu polskiego i publikacje tegoż zarządu.

[1807-1814]

Poszyt, papier, do konserwacji, rękopis/druk, język polski, niemiecki, $461 \mathrm{~s}$.

A. Jak., K.; sygn.tymez. ZC-B/71.

Uwagi: Dawniej część K.b. Vol. XIII. Pieczęcie władz państwowych w tym króla, ministra spraw wewçtrznych, podprefekta powiatu toruńskiego i toruńskiego magistratu.

\section{9}

Klasztor. Rezolucje w interesach klasztornych zarządu polskiego i publikacje tegoż zarządu. Publica Rządu Polskiego.

[1808-1809]

Poszyt, papier, do konserwacji, rękopis/druk, język niemiecki, polski, $160 \mathrm{~s}$.

A. Jak., K.b. Vol. XIII; sygn. tymez. ZC-B/72.

\section{Sprawy sądowe}

\section{0}

Proces klasztoru o zwrot majątków i przywilejów zaprzepaszczonych w czasie reformacji.

[1554-1605]

Teczka, papier, stan dobry, rękopis, język łaciński, $232 \mathrm{s.}$

A. Jak., teka nr 2; sygn. tymcz. ZC-B/3.

Uwagi: Przsięga klasztorna w magistracie toruńskim; sprawa o zwrot przywilejów; akta procesowe o dobra i dochody szpitala Św. Ducha; zeznania zakonnic o dawnych prawach i przywilejach klasztoru; skarga klasztoru przeciwko Wróblewskiemu. ZD:Pl nr 3 i 39.

\section{1}

Transakcje i procesy pomiędzy klasztorem i szlachtą. [1591-1787]

Teczka, papier, stan dobry, rękopis, język laciński, polski, 138 s.

ADPel., Monastica XIII, Benedyktynki-Toruń, nr 9.

Uwagi: Teka zawiera między innymi procesy z Pawłem Działyńskim. ZD:Pł nr 72, 73, 74. 


\section{2}

Transakcje i procesy majątkowe ze szlachtą. [1548-1759]

Teczka, papier, stan dobry, rękopis, język łaciński, niemiecki, $222 \mathrm{~s}$.

ADPel., Monastica XIII, Benedyktynki-Toruń, nr 24.

Uwagi: ZD:P1. nr 101.

\section{3}

[Kopiariusz pism procesowych i spraw w sądach i urzędach świeckich w związku $\mathrm{z}$ rewindykcją dóbr klasztornych przez ksienię Dulską prowadzonych.]

[1585-1623]

Księga, papier, oprawa perg. zielona, stan dobry, rękopis, język łaciński, polski, 414 k., folio.

A. Jak., sygn. tymcz. ZC-B/20; A.

Uwagi: Na okładce wycięta litera A. ZD:Pł.nr 15;19;20;21;22.

\section{4}

Stosunek klasztoru do magistratu toruńskiego.

[1589-1826]

Teczka, papier, stan dobry, rękopis, język łaciński, polski, $469 \mathrm{~s}$.

A. Jak., Teka nr 4; sygn.tymez. ZC-B/ 6.

Uwagi: Zawiera: różne skargi klasztoru, układy ugodowe, sprawę o wolność spławu i wolnego polowu na Wiśle, srebra i procenty od kapiałów; straty klasztonu związane $z$ fortyfikacją; summariusz starych dokumentów krzyż.i król.: s. 194-5. ZD:Pł. nr 1 i 2.

\section{5}

[Kopiariusz pism procesowych i spraw w sądach i urzędach świeckich w związku $z$ rewindykacją dóbr klasztornych przez ksienię Zofię Dulską prowadzonych.] [1598-1612]

Księga, papier, oprawa perg. zielono- niebieskawa, stan dobry, rękopis, język polski, łaciński, 334 k.,folio.

A. Jak., sygn.tymcz. ZC-B/21; B.

Uwagi: Oznaczona literą B. Zawiera również czynsze gruntowe.ZD:PL. nr 15, 16, 17, 18.

\section{6}

Plenipotencje procesowe udzielane przez klasztor do prowadzenia procesów klasztornych. 
[1591-1783]

Tcczka, papicr, do konserwacji, rękopis, język łaciński, polski, $42 \mathrm{k}$.

ADPel., MonasticaXIII, Benedyktynki-Toruń, nr 25.

Uwagi: ZD:P1. nr 109.

\section{7}

Procesy. I. Klasztoru z Hr.Cajetanem Sierakowskim; Antonim Grylewiczem; ks. Piechowskiego z Markowskim z Małych Radovik; Panem Rabe i Piwnickim, szambelanem z Piwnic k. Torunia. II. Testamenty. Ks. Towarskiego; Pctroneli Zaleskiej; ect.

[1748-1816]

Teczka, papier, do konserwacji, rękopis/druk, język nicmiecki, polski, $514 \mathrm{~s}$.

A. Jak., K. B.Vol.X; sygn. tymcz. ZC-B/45.

\section{8}

[Akta dotyczące sporu w sprawic rzemicślników klasztornych, niecechowych, osiadłych na gruntach klasztornych.]

[1768-1814]

Teczka, papicr, do konserwacji, rçkopis, jç૮yk niemiccki, polski, $66 \mathrm{~s}$.

A. Jak., sygn. tymcz. ZC-B/ 46.

\section{9}

Dekrety kościelne.1797. Kopiariusz spraw sądowych prowadzonych przez klasztor.

[1797-1797]

Księga, papier, oprawa perg., zielony, stan dobry, rçkopis, język łaciński, poiski, 382 k.

A. Jak., sygn.tymez. ZC-B/ 25.

Uwagi: ZD:P1. nr 11, 12, 13, 14.

\section{0}

Kloster. Prozesse. Acta betreffend verschiedene Prozesse und Rechtsverhaltnisse des Benedictiner-Nonnenklosters zu Thorn. Dekrety sądowe.

[1797-1828]

Poszyt, papier, do konserwacji, rękopis, j̧̨zyk niemiecki, polski, $222 \mathrm{~s}$.

A. Jak., K.b., Vol. VI.; A. B.; P. 79; sygn. tymez. ZC-B/52. 


\section{1}

Acta Iudicialia von Kloster betreffend. [Dekrety sądowe.]

[1799-1823]

Poszyt, papier, do konserwacji, rękopis, język niemiecki, polskim, $62 \mathrm{~s}$.

A. Jak., sygn. tymez. ZC-B/36.

Uwagi: Liczne i ciekawe pieczęcie. Rady Najwyższej Rządzącej Xs. Warszawskiego, Miasta Tonınia, czy Sądu Pokoju Podtoruńskiego.

\section{Majątki ziemskie i inne nieruchomości}

\section{2}

[Ksiega granic klasztornych-kopiariusz]

[1327-1623]

Księga, papier, oprawa niegdyś perg., żółta, do konserwacji, rękopis, język łaciński, polski, 82 k., folio.

\section{A. Jak., sygn. tymez. ZC-B/16.}

Uwagi: Nadpalona. Zachowane karty mocno zniszczone, pozbawione oprawy stanowią luzy. ZD: Pł. nr 50 .

\section{3}

Majątki klasztorne w ogólności.

[1403-1823]

Teczka, papier, stan dobry, rękopis, język laciński, polski, $304 \mathrm{k}$.

ADPel.,Monastica XIII, Benedyktynki-Toruń, nr 20.

Uwagi: Młyny nad rz. Łąką; Brzeźno i jego zamiana na Młyniec; Zeghna na Wytrębowice; Przeczno; Winnica; Pigża; Młyniec; jeziora Mlewiec i Głęboczek; Folwark Kubrewski, Rybaki; Nowy Dwór; Świerczynki; Pachura; Bicrzgieł i Klin przy Baszc. ZD:Pł. nr 90-92.

\section{4}

Akt połączenia majątków klasztornych ze szpitalnymi. [1415-1415]

Tcczka, papier, do konserwacji, rękopis, język laciński, niemiecki, $12 \mathrm{k}$.

\section{ADPel.,Monastica XIII, Benedyktynki-Toruń, nr 22.}

Uwagi: ZD:Pł. nr 108. 


\section{5}

Gospodarstwo w klasztorze i majątkach klasztornych. [1446-1821]

Teczka, papier, do konserwacji, rękopis, język polski, łacińskim $92 \mathrm{k}$.

ADPel., Monastica XIII, Benedyktynki-Toruń, nr 8.

Uwagi: Pożyczki zaciaggane w klasztorze oraz przez klaszlor; najazdy na majątki klasztorne; poddani klasztorni; rzemieślnicy na gruncie klasztornym; gospodarstwo w klasztorze; sumy szwedzkie; administracja majątków klasztornych. ZD:Pł. nr 70-71.

\section{6}

Majątki klasztorne w ogólności.

[1472-1776]

Teczka, papier, do konserwacji, rękopis/druk, język polski, łaciński, $302 \mathrm{k}$.

ADPel., Monastica XIII, Benedyktynki-Toruń, nr 17.

Uwagi: Kamionki; Gziki; Rgilewo. ZD:Pł. nr 93-96.

\section{7}

Majątek klasztorny w ogólności.

[1550-1823]

Teczka, papier, do konserwacji, rękopis, język łaciński, polski, $212 \mathrm{k}$.

ADPel., Monastica XIII, Benedyktynki-Toruń, nr 18.

Uwagi: Brzeźno i Brzezinko; Folwark Golubski na Mokrem. ZD:Pł. nr 97-99.

\section{8}

Majątki klasztorne w ogólności.

[1553-1752]

Teczka, papier, do konserwacji, rękopis, język laciński, polski, $147 \mathrm{k}$.

ADPel., Monastica XIII, Benedyktynki-Toruń, nr 19.

Uwagi: Wytrębowice; Papiernia. ZD:Pł. nr 88, 89.

Urkunden=Sammlung, die Benedictiner Nonnen u. die Jacobskirche. [Nadania, korespondencja oraz wyciagi z ksiąg grodzkich i ławniczych dotyczące dotyczące spraw majątkowych klasztoru.]

[1592-1783]

Księga, papier, stan dobry, rękopis/druk, język polski, łaciński, 258 s., folio. 
APT, Klasztor cysterek-benedyktynek, B. Akta, nr 17; A.Tor., X, 5.

Uwagi: Luzy różnej prowenienicji zszyte w XIX wieku w księgę.

\section{0}

[Kwity rozliczeniowe dotyczące dóbr, dzierżaw.]

[1800-1824]

Poszyt, papier, do konserwacji, rękopis/druk, jçzyk niemiecki, polski, $468 \mathrm{~s}$.

A. Jak., K.b.Vol. XVII; sygn. tymez. ZC-B/59.

Uwagi: Na nie zespojonej z aktami okładce napis: Kloster-Bauten.

\section{1}

Acta des St.Benedictiner Nonnen Klosters zu Thorn betreffend die rückständigen Canon fur das jenige Grundstäcke auch welchem jetzt die Caserne an Nonnen Thorn. Steyt

[1805-1832]

Poszyt, papier, stan dobry, rękopis/druk, język laciński, niemiecki, $90 \mathrm{~s}$.

A. Jak., sygn. tymez. ZC-13/67.

\section{2}

Rejestr dochodów i wydatków Brzeźno i Młyniec.

[1750-1758]

Księga, papier, do konserwacji, rękopis, jçzyk polski, 74 s., dudka.

A. Jak., sygn. tymez.ZC-B/ 27.

Uwagi: Znkrf: APT, Klasztor cysterek- benedyktynek, sygn. 14a.ZD:Pł. nr 25.

\section{3}

Majątek benedyktynek toruńskich Dźwierzno, jego właściciele i jego darowizna dla klasztoru benedyktynek toruńskich przez Konopackich.

[1548-1611]

Teczka, papier, do konserwacji, rękopis, język polski, łaciński, 505 k.

ADPel., Monastica XIII, Benedyktynki-Toruń, nr 13.

Uwagi: Genealogia Rokuszów i Konopackich. ZD:Pł. nr 75-77.

\section{4}

Acta betreffend die Einziehung die dem [....] Benedictiner Nonnen Kloster zugehörig gewesenen Grundstücke von Seiten der König. Festungs. Bau Kommission 
und die Uebersicht von dem Vermogens zustande das Klosters der St. Jacob Kirche und dem Hosplital.

[1816-1826]

Poszyt, papier, do konserwacji, rękopis/druk, jধ̨zyk niemiecki, 54 s.

A. Jak., sygn. tymez. ZC-B/78.

Uwagi: Majątek klasztorny. Na okładce inną ręką napisano: Kloster Vermogen.

\section{5}

Dźwierzno.

[1633-1770]

Teczka, papier, do konserwacji, rękopis, język łaciński, polski, 197 k.

ADPel., Monastica XIII, Benedyktynki-Toruń, nr 14.

Uwagi: ZD:Pł. nr. 84-86.

\section{6}

Dźwierzno.

[1600-1815]

Teczka, papier, do konserwacji, rękopis, język łaciński, polski, $222 \mathrm{k}$.

ADPel., Monastica XIII, Benedyktynki-Toruń, nr 15.

Uwagi: Dudka z rejestrem przychodów i rozchodów z 1793, $1795 \mathrm{r}$. w pieniądzach oraz z $1796 \mathrm{r}$. w zbożu; rejestr wysiewu i wymłotu za lata 1793/94; rejestr sprzętów z 1794-1795 r. Inwentarz majętności Dźwierzno za 1700 r. ZD:Pł. nr 86 i 87.

\section{7}

Dźwierzno- dublety.

[1594-1759]

Teczka, papier, do konserwacji, rękopis, język łaciński, polski, $96 \mathrm{k}$.

ADPel., Monastica XIII, Benedyktynki-Toruń, nr 16.

Uwagi: Summariusze dokumentów za 1. 1505-1759 i z 1759 r. ZD: Pł. 1 r 83.

\section{8}

Akta tyczące się Folwarku Golubskiego. [Dokumenty i korespondencja]. [1619-1805]

Poszyt, papier, stan dobry, rękopis, język polski, laciński, 72 s.

A. Jak., sygn. tymcz. ZC-B/41.

Uwagi: Fragment ZD:Pt. nr 50. 
Akta Folwarku zakonnego [Golubskiego] na Mokrem.
[1805-1905]

P'oszyt, papier, do konserwacji, rękopis/druk.

A. Jak., sygn. tymcr. ZC-B/29.

[Kamionki Małe.] Regest Małych Kamionek od Roku Pańskiego 1749 za przełożeństwa Nayprzewielebniejszey Jeymość Panny Katarzyny Borowskiej zakonu Benedykta Swiętego klasztoru toruńskiego xsieni od dnia 3 Novembr. 1731. [Rejestr dochodów i wydatków.]

[1749-1756]

Księga, papier, oprawa uszkodzona, stan dobry, rękopis, język polski, 95 s., dudka.

A. Jak., sygn. tymcz. ZC-B/30.

Uwagi: Zmkrf. APT, Klasztor cystcrek- benedyktynek, sygn. 16a. ZD:P1. nr 54.

[Kamionki Małe.] Regestr Małych Kamionek od roku 1756 za przełożeństwa nayprzewielcbnicjszej jejmości panny Katarzyny Borowskiej klasztoru toruńskiego xsieni. [Rejestr dochodów i wydatków.]

[1756-1768]

Księga, papier, stan dobry, rękopis, język polski, 93 s., dudka.

A. Jak., sygn. tymez. ZC-B/39.

Uwagi: Zmkrf. APT, Klasztor cysterek- benedyktynek, sygn. 17a. ZD:Pł. nr 31.

272

[Kamionki Wielkie.] Rejestr Kamniński od roku 1736.[Rejestr dochodów i wydatków.]

[1736-1744]

Księga, papier, stan dobry, rękopis, język polski, 89 s., dudka.

A. Jak., sygn. tymez. ZC-B/40.

Uwagi: Zmkrf. APT, Klasztor cysterek- benedyktynek, sygn. 15a. ZD:Pł. nr 30.

[Wielkie Kamionki. Rejestr dochodów i wydatków.]

[1754-1767] [1770]

Ksiçga, papier, stan dobry, rękopis, język polski, 93 s., dudka. 
A. Jak., sygn. tymez. ZC-B/28.

Uwagi: Zmkrf. APT, Klaszlor cysterek- benedyktynek, sygn. 18a. ZD:Pl. ur 26.

\section{4}

[Nowy Dwór.] Regesta Nowodworskie za przełóżeństwa nayprzewiclebiejszej IM Panny Petronelli Chrząstowskiej xsieni toruńskiej. [Rejestr dochodów i wydatków.]

[1764-1773]

Księga, papier, stan dobry, rękopis, język polski, 93 s., dutka.

A. Jak., sygn. tymcz. ZC-B/32.

Uwagi: Zmkrf. APT, Klasztor cysterek- benedyktynek, sygn. 19a. ZD:Pt.nr 45. Inwentarz Nowego Dworl.

\section{5}

[Pigża.] Rejestr pigżyński. [Rejestr dochodów i wydatków.] [1731-1739]

Księga, papier, do konserwacji, rękopis, język polski, 91 s., dudka.

A. Jak., sygn. tymcz. ZC-B/ 37.

Uwagi: Zmkrf. APT, Klasztor cysterek- benedyktynek, sygn. 20a; ZD:Pł. nr 57.

\section{6}

[Pigża.] Regesta Pigżyńskie od roku 1747. [ Rejestr dochodów i wydatków]. [1747-1756]

Księga, papier, do konserwacji, rękopis, język polski, 95 s., dudka.

A. Jak., sygn. tymez. ZC-B/ 23.

Uwagi: Zmkrf. APT, Klasztor cysterek- benedyktynek, sygn. 21a. ZD:Pł. nr 44. Inwentarz Pigży.

Majątek benedyktynek toruńskich. Szynwałd. Majątek i kościół. [1440-1804]

Teczka, papier, stan dobry, rękopis, język polski, łaciński, $454 \mathrm{~s}$.

ADPel., Monastica XIII, Benedyktynki-Toruń, nr 12.

Uwagi: ZD: P1. nr 78 i 79. 


\section{Przychody i rozchody klasztoru. Majątek ruchomy-inwentarze}

\section{8}

Księga czynszów niemieckich duża. [Odtworzona na podstawie ogólnego kopiariusza przywilejów i czynszów]. [1311-1758]

Księga, papier, oprawa. perg., zielony, stan dobry, rękopis, język niemiecki, polski, folio.

A. Jak., nr 47; sygn. tymcz. ZC-B/15.

Uwagi: ZD: PI. nr 10.

Księga czynszów niemieckich mała. [Odtworzona na podstawie ogólnego kopiariusza przywilejów i czynszów]

[1311-1758]

Księga, papier, oprawa, perg., ziclony, stan dobry, rękopis, język niemiecki, polski, folio.

A. Jak., nr 47; sygn. tymez. ZC-B/ 15 .

Uwagi: ZD: PI. nr 10.

\section{0}

Spis inwentarza ruchomego klasztoru benedyktynek.

1474-1474

Akt, papier, małe bifolium, stan dobry, rękopis, język niemiecki, wym. 230x105 mm.

APT, Klasztor cysterek-benedyktynek, sygn. 18; A.Tor. Nr 1605, 122; Scrin.XII.15.

Uwagi: Druk: Inwentarze kościola św. Jakuba i klasztoru benedyktynek w Toruniu z l.1474 i 1817; wyd. K.Ciesielska, Zap. Hist., T. 52, z. 3; 596-598.

\section{1}

Testamenty i legaty na klasztor.

[1523-1791]

Teczka, papier, stan dobry, rękopis, język polski, łaciński, $532 \mathrm{~s}$.

ADPel., Monastica XIII, Benedyktynki-Toruń, nr 6.

Uwagi: Testamenty i legaty na klasztor i kościół św. Jakuba, procesy sądowe z tego powodu; zapis Jadwigi Kalińskiej; zapis Chojnackich. ZD:Pł. nr 67, 68, 69. 


\section{2}

Posagi benedyktynck toruńskich.

[1591-1796]

Teczka, papier, stan dobry, rękopis, język polski, laciński, $436 \mathrm{~s}$.

ADPel., Monastica XIII, Benedyktynki-Toruń, nr 5.

Uwagi: Posagi w ogólności oraz wynikłe z tego procesy; proccsy o posagi panien Doroty i Katarzyny Żołędowskich o spadek zapisany na Żołędowie oraz o posag Ewy Mazowieckiej. ZD: Pł. nr 63 i 64.

\section{3}

Kontrybucje i podatki z dóbr klasztornych.

[1599-1792]

Teczka, papier, stan dobry, rękopis, język łaciński, polski, $68 \mathrm{k}$.

ADPel., Monastica XIII, Benedyktynki-Toruń, nr 30.

Uwagi: ZD: Pł. nr 111.

\section{4}

[Rejestr dchodów i wydatków klasztoru.] [1648] [1650-1673] [1675]

Księga, papier, brak przedniej oprawy, do konserwacji, rękopis, język polski, 98 s., dutka.

A. Jak., sygn.tymcz. ZC-B/ 8.

Uwagi: Zawiera: wpłaty posagów od zakonnic oraz opłat od panien świeckich. Zmkrf.: APT, Klasztor cysterek-benèdyktynek, C, sygn. 1a. ZD: Pł. nr 56.

\section{5}

Akta klasztorne panien Benedyktynek.

[1650-1814]

Teczka, papier, do konserwacji, rękopis, język polski, łaciński, $78 \mathrm{~s}$.

A. Jak., K.b. Vol. I.a.b.; Nro.22.IV; sygn. tymcz. ZC-B/42.

Uwagi: Różne kopie pism w sprawach majątkowych i gospodarezych toruńskiej wspólnoty. Na luźnej okładce inny tytul, zob. nr. 307. ZD:P1. nr 8 .

\section{6}

Kwitacje królewskie dla benedyktynek nadające zwolnienie od akcyzy, uprawnienie do browaru i wyszynku oraz koncesja na sól.

[1670-1765] 
Teczka, papier, stan dobry, rękopis, język polski, $22 \mathrm{k}$.

ADPepl., Monastica XIII, Benedyktynki-Toruń, nr 32.

Uwagi: ZD:P1. nr 110.

\section{7}

Regesta IMCI P[anny ksieni]. Rejestr dochodów i wydatków klasztoru. [1715-1718] [1726]

Ksiçga, papicr, do konserwacji, rękopis, język polski, 80 s., dudka.

A. Jak., sygn. tymcz. ZC-B/9.

Uwagi: W dochodach jalmużny, rejestr dani, zboża otrzymanego z dóbr, bielizny i rzeczy osobistych zakonnic. Znkrf. APT, Klasztor cysterek-benedyktynek, C, sygn. 2a. ZD:Pł. nr 48.

\section{8}

Regesta klasztorne klasztoru toruńskicgo.

[1717] 1720-1722

Ksiçga, papier, do konserwacji, rękopis, język polski, 92 s., dudka.

A. Jak., sygn. tymcz. ZC-B/24.

Uwagi: Posagi, wyprawy nowicjuszek, dary i datki, opłaty dzierżawne, rozliczenia z czeladzia, spis ksiag i akt wysłanych do trybunału w 1. 1720-1722 (k. 90-92). Zmkrf. APT, Klasztor cysterek- benedyktynek, C, sygn. 3a. ZD:Pł. nr 24.

\section{9}

[Rejestr przychodów i wydatków klasztoru.] [1725-1727]

Księga, papier, bez żadnej oprawy, do konserwacji, rękopis, język polski, 174 s., dudka.

A. Jak., sygn. tymez. ZC-B/26.

Uwagi: Inwentarz dóbr Pigża. Zmkrf. APT, Klasztor cysterek- benedyktynek, C, sygn. 4a. ZD:PI. nr 59,60 .

Rejestr dochodów i wydatków klasztoru.

[1728-1736]

Księga, papier, do konserwacji, język polski, 86 s., dudka.

A. Jak., sygn. tymicz. ZC-B/11.

Uwagi: Rozliczenia z czeladzią z Brzezinka, Pigży i W. Kamionek; inwentarze tych dóbr, spis rzeczy i mieszkania pozostałego po Chojnackim, pisarzu, spisy rękopis odzieży i bielizny nowicjatu. Zmkrf. APT, Klasztor cysterek- benedyktynek, C, sygn. 5a. ZD:Pł. nr 47. 
Rejestr panny subprzeoryszy od roku 1747 zaczęty.

[1747-1753]

Księga, papier, do konserwacji, rękopis, język polski, 91 s., dudka.

A. Jak., sygn. tymez. ZC-B/18.

Uwagi: Wydatki głównie na żywność. Zkrf. APT, Klasztor cysterck- benedyktynck, C, sygn. 9a. ZD: Pł. nr 25.

Rejestr dochodów i wydatków klasztoru.

[1758-1765]

Księga, papier, do konserwacji, rękopis, język polski, 92 s., dudka.

A. Jak., sygn. tymcz. ZC-B/19.

Uwagi: Głównie wydatki na żywność. Zmkrf. APT, Klasztor cysterek- benedyktynek, C, sygn. 6a. ZD:Pł. nr 27.

\section{3}

[Rejestr dochodów i wydatków klasztoru i browaru.] Za przełożeństwa nayprzewielebniejszcy imc. Panny Petroneli Chrząstowski ksieni konwentu toruńskiego z S. O. B. Regesrt ludzi zaczynający się od 1766.

[1766-1773]

Księga, papier, do konserwacji, rękopis, język polski, 94 s., dudka.

A. Jak., sygn. tymez. ZC-B/34.

Uwagi: Na oprawie napis Rejestr Kamionck Małych. Zawicra też rejestr ze sprzedaży piwa, rozliczenia z czeladzią oraz zbiorów zboża. Zmkrf. APT, Klasztor eysterek-benedyktynek, C, sygn. 12a. ZD:PH. nr 28.

\section{4}

Regesta klasztorne rozchodi y perceptory od roku 1768. [Rejestr dochodów i wydatków klasztornych.]

[1768-1789]

Ksiçga, papier, do konserwacji, rękopis, język polski, 177 s., dudka.

A. Jak., sygn. tymez. ZC-B/33.

Uwagi: Dochody z dóbr klasztornych, wydatki na utrzymanie klasztoru, żywność, rozliczenia z czeladzią i chłopami. Zmkrf. APT, Klasztor cysterek- benedyktynek, C, sygn, 7a. ZD:Pł. mr 43. 


\section{Przychody i rozchody klasztoru. Majątek ruchomy-inwentarze}

\section{5}

[Rejestr wydatków klasztoru.] Rejestr Panny Subprzeoryszy.

[1788-1830]

Ksiçga, papier, stan dobry, rękopis, jধ̨zyk polski, 186 k., dudka.

A. Jak., sygn. tymez. ZC-B/31.

Uwagi: Wydatki na żywność, spis sprzętu i naczyń pozostających w dyspozycji subprzcoryszy.

Zmkr. APT, Klasztor cysterek- benedyktynek, C, sygn. 10a. ZD:Pł. nr 32 i 33.

\section{6}

Rzeczy klasztorne.

[1765-1825]

Poszyt, papier, stan dobry, rękopis, język polski, 34 s.

A. Jak., sygn. tymcz. ZC-B/5.

Uwagi: ZD:P1. nr 9.

Acta des Benedictiner Nonnen Klosters zu Thorn die Consumptions, Steuer, Abgabe vom Bierbrawen und was dem anhängig betreffend.

[1793-1833]

Księga, papier, do konserwacji, rękopis, język niemiecki, $48 \mathrm{~s}$.

A. Jak., sygn. tymez. ZC-B/49.

\section{8}

Kloster-Benedictiner. I. Denkwürdige Klosteranngelösung. II. Ältere Schriftliche betreffend Benedictiner Nonnen zu Thorn. III. Akta tyczące się opłat od rzemieślników. IV. Sprawy rzemieślników nieklasztornych.

[1795-1829]

Teczka, papier, do konserwacji, rękopis/druk, język niemiecki, polski, $361 \mathrm{~s}$.

A. Jak., K.b., Vol. VIII., sygn. tymcz. ZC-B/54.

Uwagi: IV.Sprawy rzemieślników nieklasztornych stanowią odrębną jednostkę w serii Varia.

Kloster. Acta des Benedictiner Nonnen Klosters zu Thorn die Forderung dessel- 
ben vom 144 Thal. An dem Königli. Preuss. Staat fur Etatsmassige Accise-Bonifikationen aus den Jahren 1809-1815 und was dem anhängig betreffend. [1797] [1809-1815] [1824]

Poszyt, papier, do konserwacji, rękopis/druk, język niemiecki, polski, $46 \mathrm{~s}$.

A. Jak., K.b., Vol. IV. a.b.; Nro. 2.IV; sygn. tymcz. ZC-B/51.

300

Akta Fandbriefów i kapitałów tak klasztornych iak i kościelnych. [1800-1800]

Poszyt, papier, stan dobry, rękopis, język polski, $14 \mathrm{~s}$.

A. Jak., sygn. tymez. ZC-B/57.

\section{1}

Acta des Benedictiner Nonnen Klosters zu Thorn: dokumenta względem 40 achtli wolnego drzewa dla klasztoru 1800.

[1800-1805]

Poszyt, papier, do konserwacji, rękopis/druk, język niemiecki, polski, $86 \mathrm{~s}$.

A. Jak., sygn. tymez. ZC-B/58.

302

[Rejestr dochodów i wydatków klasztoru.]

[1800-1829]

Księga, papier, stan dobry, rękopis, jধ̨zyk polski, 179 s., dudka.

A. Jak., sygn. tymez. ZC-B/22.

Uwagi: Wydatki na żywność. Zmkrf. APT, Klasztor cysterek-benedyktynck, C, sygn. 8a. ZD:Pł. nr 34, 35, 36 .

\section{3}

Acta des Benedictiner Nonnen Klosters zu Thorn die Forderung deselben von 602 Thal. 15 Schil. 6 Gr. an den Königl. Preuss. Staat fur Etatsmassige Holz [...] und den Jahren 1808/15 und was dem anhängig betreffend. [1800] [1808-1815] [1825]

Poszyt, papier, stan dobry, rękopis/druk, język niemiecki, polski, $68 \mathrm{~s}$.

A. Jak., sygn. tymez. ZC-B/61.

Uwagi: Na okładce późniejsze, wykonane ołówkiem, nieczytelne adnotacje. 


\section{4}

Acta des Benedictiner Nonnen Klosters zu Thorn die Forderung desselben von 788 Thl. 23 Schil. 3 Gr. wegen rückständige Competenz per Junio, Julii, August und Sept[ember] 1807 an dem Staat und was dem anhängig betreffend. [1803] [1807-1807] [1833]

Tečka, papier, do konserwacji, rękopis, język niemiecki, polski, $68 \mathrm{~s}$.

A. Jak., sygn. tymez. ZC-B/63.

\section{5}

Rezolucje z różnych subseliów w roku 1804 y 1805.

[1804-1805] [1806]

Teczka, papier, do konserwacji, rękopis/druk, język niemiecki, polski, $132 \mathrm{~s}$.

A. Jak., sygn. tymez. ZC-B/64.

306

Acta des Benedictiner Nonnen Klosters zu Thorn die Forderung dessclben von 90 Thal. für rückständigen Canon für den Staat zum Salz Magazin abgeleden Platz und was dem anhängig betreffend.

[1804-1824]

Poszyl, papier, stan dobry, tękopis/dnuk, język nicmiecki, polski, 38 s.

A. Jak., sygn. tymez. ZC-B/66.

307

Akta klasztorne panien Benedyktynek. Acta des Benedictiner Nonnen Klosters zu Thorn die Forderung desselben um 1249 Thal. 89 Schil. 5,5 Gr. wegen rückständige Competenz an den Jahr 1807 an dem Staat und was dem anhängig betreffend.

[1807-1807]

Poszyt.

A. Jak., Nro. 02. IV.

Uwagi: Poszyt zaginiony. Zachowała się jedynie jcgo oprawa wykorzystana do innych akt. Zob. III. 285 .

Acta des Benedictiner Nonnen Klosters zu Thorn die von demselben Grundstücke 
gefordechen Rauchfange Gulden Abgabe und nachgesuchte Befreiung von demselben und was dem anhängig betreffend.

[1814-1825]

Poszyt, papicr, do konserwacji, rękopis/dnuk, język niemiecki, 91 s.
A. Jak., sygn. tymez.ZC-B/75.

\section{9}

Acta des Benedictiner Nonnen Klosters zu Thorn die Forderung desselben von 69 Thal. 70 Schil. wegen Benutzug. I. Der Sache zum Magazin von den Staat und was dem anhängig betreffend. II. Patronats-Lasten zu Kirchen Dźwierzno, Świerczynek, Schoncwałd.

[1815-1823]

Poszyt, papier, do konserwacji, rękopis/druk, język nicmiccki, polski, $64 \mathrm{~s}$.

A. Jak., Nro. 19.IV;; sygn. tymez. ZC-B/77.

\section{0}

Acta des Benedictiner Nonnen Klosters zu Thorn die Forderung desselben von 591 Thal. 17 Schil. 4 Gr. rückständige Competenz pro Martz, April, May 1815 an den Staat und was dem anhängig betreffend.

[1815-1815]

Poszyt, zaginiony.

A. Jak., Nro. 18. IV.

Uwagi: Znany z oprawy.

\section{1}

Inwentarz kościoła św. Jakuba i klasztoru benedyktynek w Toruniu.

[1817-1817]

Akt, papier, stan dobry, rękopis, język niemiecki, $11 \mathrm{~s}$.

APT, AmT, C 4574, s. 164-174.

Uwagi: Druk: K. Ciesielska, Inwentarze kościola św. Jakuba i klasztoru benedyktynek w Toruniu z l.1474 i 1817; wyd. K.Ciesielska, Zap.Hist., t. 52, z. 3, s. 598 i inn.

Acta des Benedictiner Nonnen Klosters die Forderung desselben von 1314 Thal. 1 Schil. 11 Gr. wegen rückständige Competenz pro 1811/14 von den Staat was dem anhängig betreffend.

[1811] [1823-1825] 
Teczka, papier, do konserwacji, rękopis, język nicmiecki, $21 \mathrm{~s}$.

A. Jak., sygn. tymez. ZC-B/82.

\section{3}

Kloster Benedictinner. Acta des Benedictiner Nonnen Klosters zu Thorn die von demselben suchte Acisse-Bonification Einrechung der das fallsein Liquidationen und aus dem anhängig betreffend.

[1824-1826]

Poszyt, papier, stan dobry, rękopis/druk, język niemiecki, $42 \mathrm{s.}$

A. Jak., sygn, tymez. ZC-B/90.

\section{4}

Liquidation über die dem Benedictiner Nonnen Kloster zu Thorn competierenden Steuer u. Bonification für das Jahr 1824 bis c. 1833 über 175 Thal. 13 Schil. 2 Gr. Acta betreffend Steuerfreiheit von Bierbrauen.

[1824-1833]

Teczka, papier, do konserwacji, rękopis, język niemiecki, $75 \mathrm{~s}$.

A. Jak., sygn. tymcz. ZC-B/83.

\section{5}

Kwitacje i pisma rosyjskie.

[1761] [1829-1829]

Teczka, papier, stan dobry, rękopis, język rosyjski, $21 \mathrm{k}$.

ADPel., MonasticaXIII, Benedyktynki-Toruń, nr 31.

Uwagi: ZD:Pł. nr 109.

\section{Przedsiębiorstwa klasztorne}

\section{6}

Klasztoru propinacja i wiktuały, karczma i browar.

[1667-1808]

Teczka, papier, stan dobry, rękopis, język łacińnki, polski, $55 \mathrm{k}$.

ADPel., Monastica XIII, Benedyktynki-Toruń, nr 29.

Uwagi: ZD:P1. nr 110. 
Reiestra należące do intrat ka[r]czemnych w roku 1759. [Rejestr intrat karczemnych.]

[1759-1799]

Ksic̨ga, papier, do konscrwacji, rękopis, jçzyk polski, 49 s., dudka.

A. Jak., sygn. tymcz. ZC-B/48.

Uwagi: Zawiera Inwentarz Wytrębowice, rozliczenia czeladzi klasztornej Zlota Góra, Pigża, Wytrębowice, Małe Kamionki, Wielkie Kamionki, Brzezinko. Zmkrf. APT, Klasztor cysterek- benedyktynek, C, sygn. 11a. ZD:Pł. nr 29.

\section{8}

Rejestr browaru klasztornego zaczęty r[oku] P[ańskiego] 1780.

[1780-1809] [1839]

Księga, papier, do konserwacji, rękopis, język polski, 82 s., dudka.

A. Jak., sygn. tymez. ZC-B/35.

Uwagi: Zawiera także Liber Baptisatorum z 1839 r., s. 25-26. Zmkr. APT, Klasztor cysterck-benedyktynek, C, sygn. 13a. ZD:Pł. nr 55.

\section{Działalność charytatywna}

Szpital. [Historia szpitala i klasztoru.]

[1311-1665]

Księga, papier, stan dobry, rękopis, język łaciński, 25 s., kwadrant.

A. Jak., sygn. tymez. ZC-B/10, Nro.19, 55.

Uwagi: ZD:Pl. $\mathrm{mr} 46$.

Acta Man des Benedictiner Nonnen Klosters zu Thorn die wegen Ausbauung 12 mit dem Kloster verbundenen

Hospitals Gebäudes gestossene Contrakte, Quitlunge in Belege und was dem anhängig betreffend.

[1800-1826]

Poszyt, papier, do konserwacji, rękopis, język niemiccki, polski, $106 \mathrm{~s}$.

A. Jak., IV.Hospital, H. 4, Vol.IV.; sygn. tymcz. ZC-B/60. 


\section{1}

Acta Man des Benedictiner Nonnen Klosters zu Thorn die wieder Ausbau des mit dem Klosters verbundenen Hospitals-Gebäudes und was dem anhängig betreffend.

[1810-1820]

Poszyt, papier, stan dobry, rękopis, język nicmiccki, polski, $70 \mathrm{~s}$.

A. Jak., sygn. tymcz. ZC-B/73.

\section{2}

Acta Man des Benedictiner Nonnen Klosters zu Thorn die Einrechung des zu demselben gehörigen Hospitals, der Besitzung der vacant verteilen Stellen in demselben und was dem anhängig betreffend.

[1826-1826]

Poszyt, papier, stan dobry, rękopis, język niemiecki, polski, $63 \mathrm{~s}$.

A. Jak., Nro. II.IV.; sygn. tymez. ZC-B/85.

\section{Nowe fundacje klasztoru toruńskiego}

\section{3}

Klasztoru nowe fundacje w Polsce.

[1605-1642]

Teczka, papier, stan dobry, rękopis, język łaciński, polski, 34 k.

ADPel., Monastica XIII, Benedyktynki-Torun, nr 26.

Uwagi: Fundacja klasztoru w Kazimierzu, Radomiu, Łomży, Drohiczynie. ZD:Pł. nr 109.

\section{Kościoly parafialne i inne budynki klasztorne}

\section{4}

Kościół św. Jakuba.

[1359-1749]

Tečka, papier, stan dobry, rękopis, język łaciński, polski, $285 \mathrm{~s}$.

ADPel., MonasticaXIII, Benedyktynki-Toruń, nr 7.

Uwagi: Fundacje dla kościoła św. Jakuba, jego kaplic i bractw, rewindykacja koscioła, spór o prawa proboszczowskie, metryki kościelne, kontrakt na budowę oltarza i kuku, przyjęcic księdza do kościola przez ksicnię. ZD: Pt. nr 65 i 66. 


\section{5}

Budynki klasztorne.

[1520-1825]

Teczka, papier, do konserwacji, rękopis, język polski, łaciński, $52 \mathrm{k}$.

ADPel., MonasticaXIII, Benedyktynki-Toruń, ur 23.

Uwagi: Przychody klasztoru za 1. 1824/25. ZD:Pt. nr 108.

Akta betreffend Patronats-Lasten der Kloster zur Kirche in Dźwierzno, Świerczynki, Szonwałd, Konigsdorf.

[1711-1831]

Teczka, papier, do konserwacji, rękopis, taciński, polski, $96 \mathrm{k}$.

A. Jak., K.b.Vol. XVIII; sygn. tymez. ZC-B/44.

Uwagi: ZD:Pł. nr 49.

327

Kloster Bauten.

[1827-1829]

Poszyt, papier, do konserwacji, rękopis, język niemiecki, $22 \mathrm{~s}$.

A. Jak., sygn. tymcz. ZC-B/86.

\section{Varia. Różne sprawy klasztorne. Korespondencja}

\section{8}

Przeniesienic klasztoru do św. Wawrzyńca a następnie do Św. Ducha.

[1327-1425]

Teczka, papier, stan dobry, język laciński, $5 \mathrm{k}$.

ADPel., Monastica XIII, Benedyktynki-Toruń, nr 21.

Uwagi: ZD:Pł. nr 108.

Varia.

[1541-1751]

Teezka, papier, do konserwaeji, rękopis, język łaciński, polski, ok. 190.

ADPel., Monastica XIII, Benedyktynki-Toruń, nr 42.

Uwagi: Sprawa jezuitów, inwentarz dóbr Czernikowa, Obrowa, Zębowca i inne. ZD:Pł. nr 113. 
Varia.

[1551-1799]

Teczka, papier, do konserwacji, rękopis, język laciński, polski.

ADPel., Monastica XIII, Benedyktynki-Toruń, nr 37.

Uwagi: Różne przedsiębiorstwa klasztorne; młyny, papiernia browar oraz majątek Kamionki Małe i Wielkie. ZD:Pł. nr 105 i 106.

\section{1}

Korespondencja klasztorna.

[1597-1782]

Teczka, papier, stan dobry, rękopis, język laciński, polski, $503 \mathrm{~s}$.

A. Jak., Teka nr 3, sygn. tymez. ZC-B/ 7.

Uwagi: Papier. Korespondencja ksieni Mortęskiej, różnych osobistości klasztornych, benedyktynek toruńskich w ogólności, ksień toruńskich w tym Zofii Dulskiej. ZD:Pł. nr 4 i 5.

\section{2}

Varia.

[1597-1797]

Teczka, papier, do konserwacji, rękopis, język łaciński, polski.

ADPel., Monastica XIII, Benedyktynki-Toruń, nr 35.

Uwagi: Kontrakty np. z Kuczborskim, różne sprawy sądowe dotyczące granic dóbr klasztornych, papiery wysłane do Trybunału w 1722 r, inwentarze Kamionek Małych i Dużych. ZD:Pł. nr 103 i 104.

\section{3}

Varia.

[1598-1783]

Teczka, papier, do konserwacji, rękopis, język polski, laciński, ok. $136 \mathrm{k}$.

ADPel., Monastica XIII, Benedyktynki-Toruń, nr 40.

Uwagi: Rejestry ruchomości, żywego inewntarza, dóbr i karczmy w Pigży, rejestr wydatków klasztoru na kontrybucje szwedzkie 1. 1707-1709. ZD:Pł. nr 114.

Varia.

[1602-1724] 
Teczka, papier, do konscrwacji, rękopis, język laciński, polski, ok. 75 k.

ADPel., Monastica XIII, Benedyktynki-Toruń, nr 39.

Uwagi: Papiery dotyczące Łcgu - Smólnika, dzicrżawy, cxtrakty z ksiagg sądowych, sprawy sądowe, inwentarz Smólnika czyli Łegu, papiery dotyczące Folwarku Kubrowskiego. ZD:P1. nr 115.

\section{5}

Varia.

[1606-1729]

Teczka, papier, do konserwacji, rękopis, język laciński, polski, ok. 94 k.

ADPel., Monastica XIII, Benedyktynki-Toruń, nr 41.

Uwagi: Na okładce fascykułu: Korespondencja klasztorów w Toruniu i w Grudziądzu. ZD: Pł. nr 112.

\section{6}

Kloster. Acta enthaltend verschiedene Papiere aus den Zeiten des Benedictinerinen Nonnen Klosters zu Thorn.

[1606-1822]

Poszyt, papier, do konserwacji, rękopis/druk, język polski, łaciński, 398 s., folio.

A. Jak., P.76; 82, K.b. Vol. I.a.b.; sygn. tymcz. ZC-B/36.

Uwagi: Poszyt zawiera odpisy, kopie i korespondencję.

[Korespondencja konwentu, ksień i księży spowiedników w różnych sprawach.] [1608-1824]

Akła luźne, papier, do konserwacji, rękopis, język polski, laciński, $490 \mathrm{~s}$.
A. Jak., sygn. tymez. ZC-B/38.

Uwagi: Fragment ZD:Pł. nr 50.

Porwanie panien z klasztoru.

[1615-1638]

Teczka.

ADPelp., Monastica XIII, Benedyktynki- Toruń, nr 28.

Uwagi: Teka zaginiona. Prawdopodobnic chodzi o panny Ostromeckie. 
Varia.

[1621-1755]

Teczka, papicr, do konserwacji, rękopis, polski, faciński, ok.162 k.

ADPelp., Monastica XIII, Benedyktynki - Toruń, nr 36.

Uwagi: Korespondencja i notatki klasztorne w tym ksieni Dulskiej, przedsiębiorstwa klasztorne, dublety i kopie dokumentów, extrakty z ksiąg sądowych. ZD:Pł. nr 102.

Kopie różnych korespondencji klasztornych od 1795 roku do 1797. [1795-1797]

Poszyt, papier, do konserwacji, rękopis, język niemiecki, polski, $90 \mathrm{~s}$.

A. Jak., K.b. Vol. XVI; sygn. tymcz. ZC-B/ 50.

Uwagi: Dawnicj fascykuł ten wchodzil w skład 1 Teki, podzielonej nie wiadomo kiedy na kilka częśsi.

\section{1}

Copie różnych korespondencji 1798-1802. [1798-1802]

Poszyt, papier, do konserwacji, rękopis, język niemiecki, polski, $147 \mathrm{~s}$.

A. Jak., K.b. Vol. XVI; sygn. tymcz. ZC-B/55.

Uwagi: Dawnicj fascykuł ten wchodził w skład 1 Teki, podzielonej nie wiadomo kiedy na kilka części.

\section{2}

Copia Varium Corespodentiarum ab Anno 1802 bis 1805. [1802-1805]

Poszyt, papier, do konserwacji, rękopis, język niemiecki, polski, $60 \mathrm{~s}$.

A. Jak., K.b. Vol. XVI; sygn. tymcz. ZC-B/62.

Uwagi: Papier. Dawniej fascykuł ten wchodził w skład 1 Teki, podzielonej nie wiadomo kiedy na kilka części.

Kopie różnych korespondencji klasztornych. [1804-1812]

Poszyt, papier, do konserwacji, rękopis, język niemiceki, polski, $128 \mathrm{~s}$. 
A. Jak., K.b. Vol. XVI; sygn. tymez. ZC-B/69.

Uwagi: Dawniej fascykuł ten wchodził w skład 1 Teki, podzielonej nie wiadomo kiedy na kilka części. .

\section{4}

Korespondencja Ks. Wojciccha Piechowskiego w sprawach klasztornych i prywatnych. II. Korespondencja ksień i klasztoru.

[1810-1831]

Teczka, papicr, do konserwacji, rękopis, język niemiecki, polski, $197 \mathrm{~s}$.

A. Jak., K.b. Vol. XV; Vol. XVII; sygn. tymcz. ZC-B/74.

\section{5}

Kopie różnych korespondencji klasztornych.

[1818-1824]

Poszyt, papier, do konserwacji, rękopis, jœ̨zyk niemiecki, polski, $132 \mathrm{~s}$.

A. Jak., K.b.Vol. XVI, sygn. tymcz. ZC-B/80.

Uwagi: Dawniej wehodził w skład 1 Teki, podzielonej nie wiadomo kiedy na kilka części.

\section{Extranea. Dokumenty i akta nie związane z klasztorem}

\section{6}

Akta nieklasztorne.

[1502-1833]

Teczka, papicr, stan dobry, rękopis/druk, język polski, łaciński, $684 \mathrm{~s}$.

ADPel., Monastica XIII, Benedyktynki-Toruń, nr 11.

Uwagi: Święcenia i pozwolenia na ich udzielenic, varia, jesuitica, odpisy z akt grodzkich krakowskich dotyczące kanoników regularnych przy kościele Bożego Ciała w Kazimicrzu, relikwic, sprawa toruńska, karmelitanki warszawskie. ZD:Pł. nr 80, 81, 82.

\section{7}

Akta dominikańskie.

[1592-1832]

Teczka, papier, stan dobry, rękopis, polski, laciński.

ADPel., MonasticaXIII, Benedyktynki-Toruń, nr 10.

Uwagi: Następnie przeniesione do: Monastica XIII, Dominikanie-Toruń, nr 3. Do Pelplina trafily z Archiwum parafii pod wezwanieın św. Jakuba w Toruniu 28.IV.1999 r. Adnotacja w teczce. 


\section{8}

Akta odnoszące się do biografii ojca Wojciecha Babeckiego, wybitnego dominikanina torunskiego (zm. ok. 1840 r.)

[1772-1838]

Teczka, papier, stan dobry, rękopis, polski, łaciński.

ADPel., MonasticaXIII, Benedyktynki-Toruń, nr 10.

Uwagi: Następnie przeniesione do: Monastica XIII, Dominikanie-Toruń, nr 3a. Do Pelplina trafiły z Archiwum parafii pod wezwaniem św. Jakuba w Toruniu 28.IV.1999 r. Adnotacja w teczce.

\section{9}

1725, 14 marca

Prosper Columan, notariusz i generalny audytor podaje do wiadomości duchowieństwa, że dominikanie w Toruniu wnieśli apelację o utrzymanie przywilejów otrzymanych przy założeniu klasztoru w 1263 r. oraz o pozostawienie im kościoła w Kaszczorku.

Dokument, Oryg., pcrg., stan dobry, rękopis, język łaciński, wym. 396x281 mm.

A. Jak., nr 38.

Uwagi: Pieczęć wystawcy.

\section{0}

Desciptio status ecclesiae s. Nicolai...ad coenobium fratrum ord. Predic. Mandato...patris Jucandi Trąbski provincials sub tempus prioratus prioris Andreae Rapiowski facta a.D.1785 diebus Augusti.

[1785-1785]

Księga, papier.

A. Jak., nr 53.

Uwagi: Księga ta zawiera również opisy grobów i nagrobków znajdujących się w koścjele św. Mikołaja.

\section{1}

1793,3 maja

Jan Chrzcicicl Moretti, prokurator trzeciego zakonu świętego Dominika przyjmuje w poczet tercjarzy Teodora Lazarowicza, nadając mu przy tym przywilej noszenia habitu.

Dokument, Oryg., perg., stan dobry, druk, język łaciński, wym. 517x332 mm.
A. Jak., nr 47. 


\section{DAS INVENTARVERZEICHNIS DER AKTENGRUPPE DER ZISTERZIENSERINNEN (BENEDIKTINERINNEN) IN THORN AUS DEN JAHREN 1311-1833}

\section{Zusammenfassung}

Das Inventarverzeichnis der Akten der Thorner Zistcrzienserinnen (Benediktinerinnen) umfasst. die Jahre 1311-1833, d.h. den gesamten Zeitraum des Wirkens der Verfasser dieser Akten. Das vorlicgende Inventarverzeichnis hat idealen Charakter. Seine Aufgabe ist es, alle, auch dic verstreuten und nicht bis heute erhaltenen Archivmaterialien zusammenzutragen, die jemals zum Bestand des Archivs der Thorner Zisterzienserinnen (Benediktinerinnen) gehört haben. Es soll veschiedene Funktionen erfüllen: die reale Rettung der Akten verbesern helfen und den Erforschem des weiblichen Monastizismus die Suche erleichtern, die sich für dic Geschichte der Kongregation von Chcłmno (Culm), der Ordensgemeinschaft in Tonú (Thom) oder detaillierte Aspekte seiner Tätigkeit intcressieren.

Die zu dieser Aktengruppe gehörenden Archivalien befinden sich vor allem in folgenden Archiven: im Diözesanarchiv in Pelplin, im Staatlichen Archiv in Torun sowie im Archiv der Pfarrkirche St. Jakob in Toruń und im Archiv für Alte Akten der Thorner Diözese in Torun (seit Anfang 2005 werden dort auch Akten aus der Abteilung Monastica aufbewahrrt, die ihm vom Diözesanarchiv in Pelplin übergeben wurden). Die heute nicht mehr existierenden Materialien konnten zum Teil rekonstruiert werden, und zwar dank mehrerer Quelleneditionen zur Geschichte der Diözese Culm, der Stadt Thorn und sogar der Thorner Ordensschwestern selbst. Dies sind Dokumente und Akten, die als Ganzes veröffentlicht oder im ,Preußischen Urkundenbuch” (Bd. I-VI, Königsberg 1882 Marburg/L. 1986), im „Urkundenbuch des Bisthums Culm” (Bd. I-II, bearb. v. C. P. Woelky, Danzig 1885-1887) sowie in „Kronika Bencdyktynek Toruńskich” (hrsg. v. W. Szołdrski, Pelplin 1934) regestiert wurden. Diese Materialien wuren auch dank des von Carl Peter Woelky herausgegebenen „Regesten und Urkunden-Verzeichnis über das Benedictiner-Jungfrauenkloster in Thorn" (,Altpreußische Monatsschrift", Bd. 17, H. 7-8, S. 589-642) sowie des Kopienbuches der Kloster- und Ablassprivilegien rekonstruiert, welches sich im Archiv der Pfarrei St. Jakob in Toruń befindet.

Den genannten Materialicn wurde ein gemeinsames Systcm verliehen, indem die Methode der Ordnung dieser Aktengruppe nach Sachgebieten angewandt wurde, aber trotzdem wurde die in allen obige Archivalien aufbewahrenden Archiven bestehende Eintcilung in Dokumente und andere Kanzleiformen beibehalten.

Die Gliederung der Akten der Thorner Zisterzienserinnen (Benediktinerinnen) nach Sachgebieten (351 Archiveinheiten) umfasst zwölf Reihen: Dokumente; Organisation. Tägliches Leben und geistliche Gemeinschaften; Anordnungen der geistlichen und weltlichen Oberen. Korrespondenz; Gerichtssachen; Landgüter und andere Immobilien; Einkünfte und Ausgaben des Klosters; Unternehmungen des Klosters; Karitative Tätigkeit; Neue Stiftungen des Thorner Klosters; Pfarrkirchen und andere Klostrgebäude; Varia. Verschicdene Klosterangelegenheiten. Korrespondenz; Extranea. Nicht mit dem Kloster im Zusammenhang stehende Akten.

Aufgrund des Idealcharakters des Inventarverzeichnisses und seiner Ziele: u.a. der Information über den heutigen Zustand und den Aubewahrungsort der jeweiligen Archiveinhciten, die dieser Aktengruppe angehören, wurden im Rahmen der eingerichteten Reihe „Dokumente” alle sich in den Beständen der genannten Archive befindlichen Archiveinheiten erwähnt (neben den heute nicht mehr existenten). Dies verursachte jedoch gewisse Komplikationen. In dieser Reihe befanden sich (in wenigen Fällen) sowohl die Originale als auch die Kopien derselben Dokumente. Um dic in den Dokumenten auftretenden Inkonsequenzen hinsichtlich der Benennung oder Deklarierung der Thorner Ordensschwestern als Zisterzienserinnen oder Benediktinerimnen zu vereinheitlichen, wurde der Begriff ,Zisterzienserinnen (Benediktinerinnen)" verwendet (die Information über die darin selten vorkommende Bestimmung der Ordenszugehörigkeit des Verfassers dieser Aktengruppe wurde in die Anmerkungen verlegt). Danach, als dieser Orden der Kongrcgation von Culm beigetreten war, wurden sie als Benediktinerinnen bezeichnet.

Im Falle aller erhaltenen Titel der Inventareinheiten wurde deren Originalschreibweise beibehalten. Wegen des idealen und nicht realen Charakters des Inventarverzeichnisses wurde bein Ordnen weder eine Verbindung noch cine Trennung der existierenden Archiveinheiten durchgeführt (vor 
allem deshalb, weil nicht nur die Lücken aufweisenden Aktenmappen oder -bündel, sondern auch die alten Eintragsbüicher unterschiedliche Inhalte besaßen). Daher wurden sie derjenigen Reihe zugeordnet, die von ihrem Titel oder von der Mehrhejt der in ihnen enthaltenen Materialien suggeriert wurde, wobei auch Anmerkungen über in ihnen enthaltene andere, eher unerwarteter Informationen gemacht wurden. Ebenfalls wegen des erwähnten Charakters des Inventarverzeichnisses wurde die Reihe „Varia. Verschiedene Klosterangelegenheiten. Korrespondenz” eingerichtet (d.h. die als Varia bezeichneten Einheiten wurden nicht getrennt und nicht neu bearbeitet; in den Anmerkungen wurde versucht, über den Inhalt der so geschilderten Akten zu informieren). Eine weitere Ausnahme bildet dic Reihe „Extranea. Nicht mit dem Kloster im Zusammenhang stehende Akten”, in die neben Büchem und Akten auch zwei Dokumente Eingang fanden. Ausnahmsweise wurde ihnen gegenüber eine Einteilung nach Sachgebieten vorgenommen, nicht nur wegen ihrer geringen Zahl, sondern auch deshalb, weil sie auf keine Weise mit der Existenz und dem Wirken der Thorner Zisterzienserimnen (Benediktinerimnen) verbunden sind. Im vorliegenden Inventarverzeichnis wurde das in den Archivmaterialien gefundene Verzeichnis der Bücher aus der Konventualbibliothek der Thorner Ordensschwestern von 1617 nicht berücksichtigt, weil dieses den Gegenstand einer besonderen Publikation bilden wird (daher wurde die Reihe „Bibliothek” außer Acht gelassen).

Da sich die zusammengestellten Materialien in vcrschiedenen Archiven befinden, bezeichnet dic erste frühere Signatur den letzten Aufbewahrungsort der jeweiligen Archiveinheit. Auch wurde im Fall der Rekonstruktion einer heute nicht mehr existenten Einheit oft anstelle der früheren Signatur die Quelle der Hcrkunft der Information über die Einheit oder ihren Inhalt angegeben, unter zusätzlicher Beifügung veschicdener Details zu diesem Thema in den Anmerkungen. Im Text des veröffentlichten Inventarverzeichnisses wurden, im Rahmen der oben genannten Reihen, unter Beibehaltung der durchlaufenen Nummerierung die einzelnen Archiveinheiten erwähnt. Thre Beschreibung setzt sich aus folgenden Elementen zusammen: Datum und Ort der Ausstellung (in der Reihe „Dokumente"); Aufzeichnung des Originaltitels bzw. des sich herausgebildeten Titels; Extremdaten der Einheit (in den übrigen Reihen) sowie eventuelle Anteriora und Posteriora; sowie falls möglich auch: Beschreibung der äußercn, physischen Gestalt der Einheit; Sprache; Zahl der Blätter oder Seiten; Format der Inventareinheit; frühere Signaturen; archivalische und historische Bemerkungen sowie bibliographische Angaben.

Aus dem Polnischen überselzt von Herbert Ulrich 